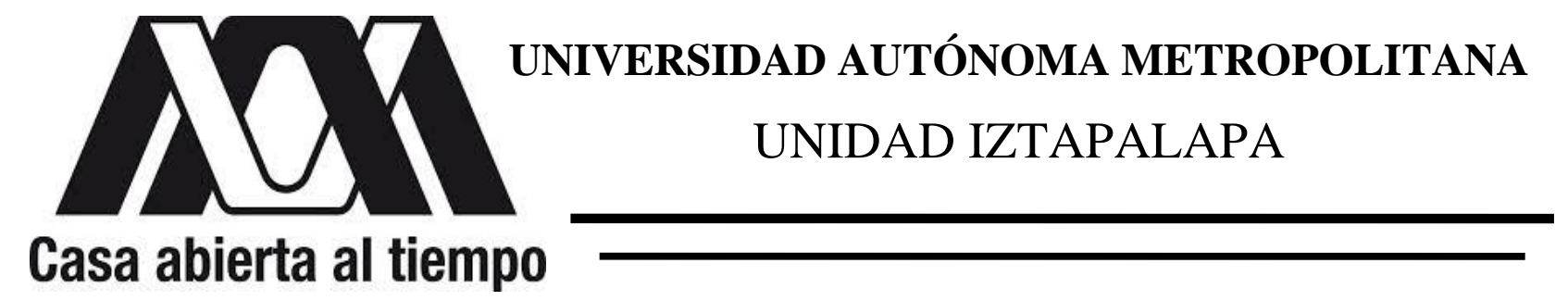

DIVISIÓN DE CIENCIAS SOCIALES Y HUMANIDADES

\title{
"LA POESÍA Y SU UTILIDAD HISTÓRICA: WALT WHITMAN, SU OBRA Y LA GUERRA CIVIL"
}

TESIS QUE PRESENTA

\section{GABRIEL GARCÍA IGLESIAS 2183800608}

PARA OBTENER EL TÍTULO DE

\section{MAESTRO EN HUMANIDADES (HISTORIA)}

\author{
DIRECTOR: DR. GEORG LEIDENBERGER \\ LECTOR: DRA. ADRIANA MARÍA HERNÁNDEZ SANDOVAL \\ LECTOR: DR. CHRISTIAN CURT SPERLING
}




\section{LA POESÍA Y SU UTILIDAD HISTÓRICA: WALT WhitMan, SU ObRA Y LA GUERRA CiVIL}

POR GABRIEL GARCÍA IGLESIAS 


\title{
A Sabina:
}

gracias por no soltar mi mano y soportar cada etapa de esta aventura. Tus ojos —que fluyen, transforman y ofrecen el mejor paisaje en la mañana- han sido mi gran motivo para nunca rendirse. De la mano y sin desviar la mirada, fluyamos como lo hace el agua en la mar.

A mi madre:

por seguir al pendiente de mí, así como de mis logros, derrotas y crisis. En este último año me diste el ejemplo de resistir y combatir las adversidades de la vida. Gracias por nunca rendirte. Todo lo que soy te lo debo a ti.

\author{
A Emma: \\ por ser la luz que iluminó los momentos de penumbra e \\ incertidumbre.
}

A mi hermana:

por ser mi más grande ejemplo de tenacidad, perseverancia y apoyo incondicional.

A mis maestros, amigos, familiares, alumnos y colegas. Su apoyo cimienta este trabajo. Cada uno de ustedes se encuentra en las letras, versos e ideas. Gracias totales. 
ÍNDICE

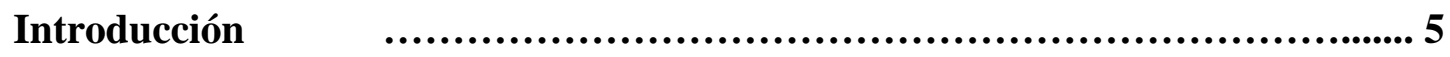

Estado del arte y las fuentes ................................................. 12

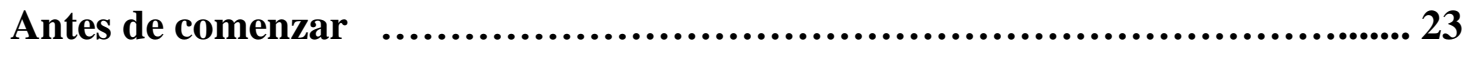

Capítulo I. Destellos de vida: poeta-poema-realidad $\quad$................................. 24

Familia y nación: observar la realidad $\quad$..................................... 31

La juventud: volverse parte de la realidad .................................... 39

La fuerza de la voz: nombrar la realidad ................................... 47

Un mismo ente: el poeta, la guerra y su obra $\quad$............................6 60

Walt Whitman y la Guerra Civil Estadounidense (1861-1865) _............ 73

Capítulo II. Whitman: poeta o historiador de la Guerra Civil (1861-1865) ...... 74

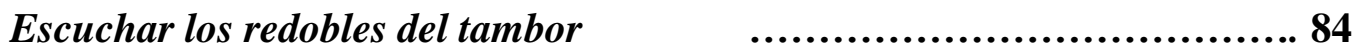

Instantes de descripción expresión y evocación $\quad$.............................. 103

Capítulo III. La poesía en la historia: utilidad y límites ........................... 114

Poeta-poema-realidad $\quad$...................................... 116

La utilidad del vínculo inquebrantable $\quad$.................................... 123

Los límites de la poesía en la historia $\quad$.................................... 133

Consideraciones finales $\quad$..................................................140

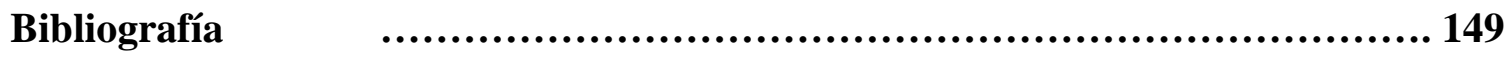




\section{INTRODUCCIÓN}

Cuidémonos de quitar a nuestra ciencia su parte de poesía. Cuidémonos, sobre todo, como he descubierto en el sentimiento de algunos, de sonrojarnos por ello. Sería una formidable tontería pensar que por tan poderoso atractivo sobre la sensibilidad, tiene que ser menos capaz de satisfacer a nuestra inteligencia.

Marc Bloch

Hace años descubrí que son las vidas de los otros las que merecen ser contadas. Y sólo a través de ella he podido llegar a comprender algo de la mía.

José Manuel Fajardo

Perhaps if "poetry" runs too far from the World, it leaves history to do all the work and does not provide another kind of memory, critique and protection. Perhaps if history gets too mired in the world, it loses shape and a style to make it memorable or attractive to readers lost in statistics, graphs and arid discourse.

Jonathan Hart

La poesía también contiene conocimiento sobre el pasado. No se debe olvidar que la historia recolecta, asimila y confecciona las evidencias realizadas por el hombre dentro de un tiempoespacio preciso. Cuando un poeta capta su cultura, individualidad, sociedad y época en un poema, la poesía también se convierte en un contenedor de información sobre un suceso. Con base en este supuesto, mi investigación intenta plantear formas, utilidades, además de posibilidades y límites, de lo poético en el quehacer histórico.

Al quedar atada de un poema, la poesía requiere — como cualquier otro documentoun examen, una contextualización y una valoración crítica. Su utilidad histórica no sólo refrenda el estilo y la capacidad de quien la escribe. Tampoco busca comparaciones ante otras formas de registro. Menos aún se sostiene como una fuente fidedigna por sí misma. Su acceso al pasado debe suceder a través de la realidad y la obra de un autor. Allí radica su fuerza y utilidad para recrear un acontecimiento.

Un poeta se inserta en una trama social concreta donde desarrolla su capacidad creativa. En sus poemas se resguarda información valiosa sobre algún hecho histórico. Ahí 
surge una relación inquebrantable entre poesía e historia mediada por la presencia del poeta. Si la poesía busca una oportunidad de convivencia y adición a un suceso, ésta comienza en la vida del escritor. Por tal razón, mi trabajo busca entender a un individuo y su realidad con base en una relación recíproca e irrompible.

El poeta significa la relación entre realidad y lenguaje. Sus creaciones son el resultado de su idiosincrasia, las exigencias de su época, así como las de su entorno sociocultural. A pesar de la variedad de estos factores, el poeta se adueña de su tiempo-espacio y lo recrea a través de palabras, de instantes. Ese resultado adquiere una fuerza interpretativa individualcolectiva de la realidad. Como tal, también puede servir para entender los hechos sucedidos en algún momento en el pasado.

Para sustentar lo anterior, la investigación inicia con la vida y el trabajo de Walt Whitman (1819-1889), un canon de la literatura norteamericana y universal. Sus poemas contienen meditaciones sobre el cuerpo y el alma, la sexualidad, así como un amor incuestionable hacia su nación. De igual manera, contienen grandes debates sobre situaciones que azotaron a los Estados Unidos durante el siglo XIX: esclavitud, libertad, democracia, la propia Guerra Civil. Aquel poeta tuvo la capacidad de combinar sutilezas y sentimientos con los hechos a su alrededor.

Su canonicidad descansa en la capacidad de influenciar las letras de otros autores. Eliot, Hemingway, Stevens, Pound o Faulkner, lo retomaron para representar y fundamentar lo exclusivo de los Estados Unidos. Whitman fue el punto de partida, de definición permanente, sobre la imagen y la voz de esa nación: a veces estoica, heroica, amorosa o reconciliadora. Con diferentes tonos trató de unir los elementos de su sociedad para pertenecer a una sola realidad. 
Por si fuera poco, Whitman acapara los reflectores no sólo a nivel nacional. Bloom (2019) considera a Eliot y a Faulkner como los más próximos en inspirar letras. Sin embargo, les falta el reconocimiento mundial: "en el extranjero, la literatura norteamericana es siempre, en primer lugar, Whitman, ya sea en la América de habla hispana, o en Japón, Rusia, Alemania o África" (p. 301). Con sus palabras, ese poeta habló del origen de una nación en tiempos de definición, metas y acciones. Por esta razón, no sólo se reconoce su canonicidad y fama internacional, también su valor histórico.

Whitman sustentó su obra en relación directa con los hechos nacionales. Ahí radica su elección para ser la columna vertebral de esta investigación. Si bien sus Hojas de hierba metaforizaron el "yo" como parte de un todo, así como la innovación de la métrica, también existe una obra acotada al marco de la Guerra Civil (1861-1865). Redoble de tambor funciona como el vestigio, el documento, donde captó, creó y socializó las experiencias de una colectividad; más allá de lo experimentado por un individuo.

Ese poemario capturó instantes históricos de una nación. Además, formó parte de los testimonios de la guerra, donde se concentraron experiencias individuales y colectivas. En cada verso no sólo se escucha el avance de los ejércitos o el terror en el campo de batalla. También se congelan la camaradería, el deseo, el afecto y la idea de unión. Los sonidos del tambor llevaron al trabajo de Whitman a otros alcances. Ya no bastaba con la idea y los deseos de un hombre por pertenecer a su país. Redoble también podía servía como una memoria más de la historia nacional.

Aquellos versos guardan la visión, participación y experimentación de un hombre de los derroteros de la Guerra de Secesión. Aunque sólo introduce la mirada del poeta, su obra logra aportar información al respecto de un hecho en el pasado. El tambor puede escucharse como un collage de testimonios: de la valentía de los combatientes, de los observadores, de 
lo salvaje que puede ser un enfrentamiento. Las percusiones guardan la voz del poeta cuando testificó el panorama de los hechos, así como de quienes padecieron e hicieron eco de sus horrores.

Con lo anterior enfatizo el objetivo de mi investigación: demostrar la utilidad histórica de la poesía, a partir de su relación inquebrantable con el hombre, el pasado y sus creaciones. Este fin debe suceder a partir de tres momentos, de tres capítulos. En el primero resaltaré la utilidad histórica de una relación inquebrantable: poeta-poema-realidad. El poeta abre un diálogo entre hombres y dioses donde brinda de permanencia a las palabras. Une su lenguaje con los hechos a su alrededor para crear un poema. Sus creaciones enriquecen la comprensión de sucesos personales y nacionales. En ese vínculo irrompible descansa la utilidad de la poesía para el pasado.

El apartado inicial no abarca toda una vida, sino sólo algunos destellos biográficos de Walt Whitman: desde su nacimiento hasta la conclusión de la Guerra Civil (1819-1865). Esa duración contiene vivencias, así como elementos culturales y sociales adaptados en la obra del poeta - niñez, problemas familiares, labores periodísticas, así como distintas situaciones nacionales-. Aquellos momentos permiten conocer el trayecto del individuo hacia convertirse en el canon de la literatura estadounidense. La investigación se detiene al término de la guerra y con la publicación de la cuarta edición de sus Hojas de Hierba.

Después de las hostilidades, Whitman alcanzó un punto de no retorno. En 1865, sus letras expresaron lo que deseaba comunicar; alcanzaron la cúspide de su genio literario. Si bien sus primeras creaciones no lo llevaron a conquistar la cima, la edición posterior al conflicto complementó y actualizó los logros del escritor. Por esta razón, el capítulo no abarca toda una vida, sino los momentos donde se observa y se reconoce la individualidad, el proceso de su obra hacia la cumbre, la vida nacional, así como la interacción entre ellos. 
Al no abordar toda una vida, se puede ahondar en los momentos de lucidez en el poeta. Más allá de su infancia y formación intelectual, la Guerra Civil es un apartado relevante: el paso de Whitman por los hospitales mermó su salud, pero dichos episodios motivaron un cambio en sus letras. La historia individual no sólo señala la extraordinaria voz poética, sino también instantes de dolor, sufrimiento o vulnerabilidad. La tarea del primer capítulo se dirige a explorar al escritor, a las regiones ocultas de su persona y pensamiento, mientras aspectos culturales, políticos y sociales salen a flote.

De esa manera, la investigación explora la existencia e intelecto de un hombre en tiempo y espacio precisos. Walt Whitman forjó su obra, al igual que su rol como poeta, al entramarse con diversas situaciones nacionales. Absorbió su entorno -y viceversa- para sustentar su voz ante los hechos. Los momentos seleccionados rastrean experiencias para recrear un fragmento en la historia del individuo, así como en los hechos ocurridos en los Estados Unidos. Ahí busco demostrar la utilidad histórica de la relación inquebrantable entre el hombre, el pasado y sus creaciones.

No basta con descubrir la correspondencia entre poeta-poema-realidad. El segundo capítulo de la investigación destaca la obra poética, más que la vida del autor. El trabajo de Whitman merece atención especial pues representó la racionalidad de su realidad. Lo racional debe pensarse como la percepción del tiempo - no lo actual-, sino como los momentos creativos del escritor. El poeta y su obra se adaptaron a las exigencias de su entorno para testimoniarlo. Al originarse en situaciones precisas, los versos significaron la adherencia histórica entre el escritor y los hechos a su alrededor.

La segunda sección invita al encuentro de un hombre con su propio lenguaje, a los instantes poéticos creados. Whitman elaboró su verdad como un representante verdadero de su pueblo; desde su propia perspectiva, en forma de poemas, recreó y amplió lo sucedido 
durante la Guerra Civil. Redoble de tambor valida la memoria de un hecho plasmado en palabras. Cristaliza instantes capaces de acercar a los lectores al lenguaje del poeta, a la sociedad, así como a un periodo crucial en la historia de una nación.

La discusión del segundo apartado circunda la obra del poeta durante el conflicto: el patriotismo y el júbilo de los primeros poemas; así también, el cambio de tono y perspectiva. La investigación retoma la experiencia misma del escritor y su cambio de visión ante la crueldad y salvajismo de la guerra. Así también, apela al análisis de los versos a partir de tres propiedades útiles para la historia: la descripción, la expresión y la evocación. Los instantes poéticos creados por Whitman guardan propiedades e información útil-enriquecedora de aquel tiempo.

Con esta tercia analítica pretendo elaborar una relectura de Redoble de tambor. Esto me permite observar los instantes escritos por el poeta sobre los cambios y los estragos de la guerra. Ese poemario sustenta la visión de un hombre y al mismo tiempo guarda un collage de testimonios, de valentía, así como del salvajismo. Su obra recoge la voz de los soldados, así como la de los contempladores del conflicto; rompe la barrera individual y muestra la realidad colectiva de una nación. Así es como Redoble también se añade como una memoria más de la historia de los Estados Unidos.

Existe una diferencia evidente entre los dos primeros capítulos. El primero habla sobre la vida de Whitman; ahí se enseña la manera de lidiar y superar adversidades, limitantes o carencias. También se muestra como cada de esas vicisitudes le ayudaron a forjar su genio como escritor. Sin esas experiencias, ningún verso pudo haber visto la luz. En el segundo capítulo, se escuchan los versos desde una perspectiva histórica. Ahí se devela la información guardada en las letras. Se miran los estragos individuales y colectivos a partir de la lectura de instantes poéticos cargados de descripción, expresión y evocación. 
Las dos primeras secciones guardan diferencias claras y al mismo tiempo arrojan la temática del tercer apartado. Después de mostrar la vida y la relación entre el poeta, su obra y la realidad, queda pendiente una discusión: las oportunidades de la poesía en el dominio de la historia. El tercer capítulo retoma el vínculo entre la poesía y la inquebrantable tercia poetapoema-realidad. Con ello busco demostrar cómo y hasta dónde, tal unión puede aportar a una investigación histórica. Así surge el objetivo de ese apartado: evidenciar la utilidad y los límites de lo poético en el pasado.

Como un primer paso, la poesía debe asirse de una figura humana, de un guardián y un contenedor de realidad: el poeta. Cuando el escritor dialoga con ella para después plasmarla en un texto, sucede un efecto de liberación y expresión. Él la pronuncia a través de un cúmulo de palabras, la llama; ella le responde. Ambos se entraman en una relación recíproca, donde ninguno existe sin el otro. De esta manera, el poeta hace que la poesía se exprese y habite en la realidad; que se entienda y se aloje en el pasado.

La poesía aporta información a una investigación histórica al limitarse y llenarse de virtud humana. En ella caben todos los discursos y posibilidades, es el espacio de lo sugerente, de lo absurdo, de la falacia. Es el campo del lenguaje, de todas las palabras ritmos, imágenes y metáforas que el hombre puede arrancarle al mundo. El lenguaje de la poesía expresa y habita un complejo verbal que dialoga con el tiempo. Allí es cuándo y dónde este tipo de palabras adquieren utilidad histórica.

Los límites humanos no sólo atan, transforman a la poesía en una obra de arte. Vuelta un producto artístico, expone las exigencias de una época, de un ambiente cultural y de la idiosincrasia de su autor. En palabras simples, la poesía, sujetada del poeta, queda plasmada en un documento. Éste adquiere valor artístico si referencia al pasado con base en la existencia y la capacidad del poeta por describir, expresar y evocar un momento de su 
realidad. El arte es una reciprocidad entre creación y creador. La poesía necesita del poeta y del poema para revelarse en el terreno histórico y viceversa. Una obra de arte testimonia las exigencias de vida, individuales y colectivas, de su creador.

El tercer capítulo difiere de sus antecesores en acento y estructura. Este apartado se origina desde la reflexión de lo escrito e investigado. Las dos primeras secciones contienen una breve discusión historiográfica al inicio. Allí los expertos hablan y se retoman algunas de sus ideas para elaborar un documento. En el tercero, mi voz pretende discutir de manera directa con las ideas de los estudiosos de la poesía y la historia. La última parte es el sitio donde mis palabras buscan aportar e innovar la comprensión del pasado.

Con ayuda de cada sección, mi investigación intenta demostrar las posibilidades de la poesía en el terreno de la historia. Su acceso sucede a través de la existencia y el trabajo de un autor. A su vez, en la obra habita conocimiento enriquecedor sobre algún hecho. Así surge la relación inquebrantable entre poesía e historia mediada por la presencia del escritor. Esta es la idea a perseguir: la poesía logra testimoniar tanto al individuo, su contexto y su obra por medio de una relación recíproca e irrompible.

\section{Estado del arte y las fuentes}

Como se mencionó, mi trabajo se desarrolla en tres momentos. El primero retoma la existencia de Walt Whitman, así como la historia de los Estado Unidos. El segunda trata sobre la obra del poeta. En esta sección, la investigación redirige los reflectores hacia los poemas de Redoble de tambor. En ese poemario habita una perspectiva histórica de la Guerra Civil. En el último apartado se habla de cómo la información escrita en los versos puede añadir conocimiento sobre un hecho. Debido a los distintos temas, la historiografía revisada debe tener particularidades para cada momento. 
Referente al primer capítulo, la vida del poeta es la protagonista. David S. Reynolds (1995) escribió la biografía, Walt Whitman's America, a cultural biography. Ahí desarrolló detalladamente la existencia del poeta, a la par de los hechos nacionales. El historiador y crítico literario ahondó en la dimensión individual y social del poeta. Es decir, entendió al hombre y a sus creaciones a través de la realidad estadounidense del siglo XIX. Mi investigación comparte los objetivos de Reynolds: unir históricamente la existencia y la obra del poeta. Ninguno de esos aspectos debe quedar alejado uno del otro.

Félix Martín (2003), Walt Whitman, retomó muchos de los señalamientos desarrollados en la biografía de Reynolds. No obstante, su trabajo difiere y trata de encontrar la parte humana de Whitman. No sólo sintetizar los episodios más relevantes en la vida del poeta, sino también observar al personaje desde sus actitudes, fortalezas o debilidades. Martín mostró a la persona por encima del genio creador. La intimidad, los pensamientos o las decisiones del poeta también serán retomadas en este documento.

La parte humana —intelectual e íntima del poeta— no debe hacer a un lado la historia del país. Los textos sobre la historia estadounidense también fueron una pieza clave en mis argumentos. La publicación de Erika Pani (2016), Historia Minima de los Estados Unidos de América, brindó el dato duro y preciso. De igual manera, el libro de Philip Jenkins (2007), A History of the United States, soportó las puntualizaciones de la realidad decimonónica donde habitó el poeta. Aunque no fueron los únicos, tales documentos confirmaron algunos hechos compartidos entre el poeta y la nación.

La existencia de Whitman, así como los motivos de sus poemas, fue recreada por Jerome Loving (1999), Walt Whitman: The Song of Himself. En su trabajo retomó momentos icónicos de la existencia y la obra del poeta. La Guerra Civil, por ejemplo, revela el sufrimiento y la vulnerabilidad ocasionada por las hostilidades. De esa manera, con base en 
algunas experiencias de Whitman, Loving observó a cada poema como un tipo alterno de registro e información. Su biografía esboza sobre la utilidad de la poesía como una fuente de información para recrear el pasado. Mi investigación busca retomar planteamientos y argumentos inmersos en ese trabajo.

En el archivo digital Walt Whitman, existe una sección dedicada a la vida del escritor. Ed Folsom y Kenneth M. Price (2007), ordenaron episodios definitorios en breves párrafos. Allí se puede conocer de manera precisa al poeta. Para los autores, Whitman supo combinar periodismo, oratoria $\mathrm{u}$ otras fuerzas culturales para forjar una voz estadounidense innovadora. Todo con la intención de registrar y arraigar un ideal de unión en los Estados Unidos. Ellos lo consideraron como un artesano capaz de conjuntar experiencias personales con la vida nacional en cada uno de sus versos.

Con lo discutido, se abre la puerta hacia la vida y la obra de Whitman. Con ello busco entender más allá de su existencia, también su obra y algunos fragmentos en la historia de los Estados Unidos. Intento demostrar la relación inquebrantable entre poesía e historia mediada por la presencia del poeta. Mi trabajo busca entender al individuo y a la realidad nacional con base en una relación recíproca. El poeta se inserta en una trama social concreta donde desarrolla su capacidad creativa. En sus poemas cabe y se resguarda información valiosa sobre algún hecho histórico.

Después de la existencia, aparece el segundo momento de la investigación. El análisis histórico de los poemas escritos durante la Guerra Civil. El poemario Redoble de tambor es la fuente principal de esta sección. En cada verso se mira el patriotismo y el optimismo de los primeros poemas; así también, se entiende el cambio de tono y perspectiva del autor y sus letras. La investigación retoma la experiencia misma del escritor inmerso en la guerra. En esta sección, se apela al análisis de los versos. 
La historiografía consultada mira a Redoble de tambor como un testimonio individual y colectivo de la guerra. Es un poemario que contiene instantes sobre la vida nacional de los Estados Unidos. Mair Mullins (1999), en su trabajo “Stopping History in Walt Whitman's Drum-Taps", escuchó en esos versos el avance de las unidades militares o los horrores de las batallas. En ellos se enseñó la idea de unión, algo en lo que Whitman creyó fielmente. El sonido del tambor llevó al trabajo del poeta hacia otros alcances. De los argumentos de Mullins retomo el valor de cada poema como testigo del panorama, de los hechos, al igual que los actores e involucrados en la Guerra de Secesión.

Cristanne Miller (2009), en su artículo "Drum Taps: Revisions and Reconciliation”, resalta las diferencias entre la obra de Whitman con los demás poetas sobre el conflicto. Los escritores postconflicto no podían despojarse de una nostalgia regionalista. Los poetas sureños lamentaron la muerte de la Confederación. Los norteños pasaron de condenar la esclavitud y la traición sureña antes y durante la guerra, a proponer un proyecto conciliador. De este trabajo pretendo retomar este último argumento: Whitman cimentó la idea de reconciliación nacional en cada uno de sus poemas.

Para conseguir esta reconciliación, primero debió ocurrió un cambio de perspectiva en el poeta y en la nación. El conflicto interno no brindaba ninguna solución. Ese episodio en la historia estadounidense ocasionó un proyecto de reconciliación entre individuos y comunidades. La tesis de Laura López Peña (2008), The Role of the Poet in the American Civil War: Walt Whitman's Drum Taps (1865) and Herman Melville's Battle-Pieces (1866), recupera el tiempo y el espacio de una nación en guerra. La poesía se colocó como un estandarte para lograr la deseada unión. Este punto también será tratado en este documento: el valor de cada poema no omite su relevancia histórica. 
Fue así que sucedió un cambio de percepción en la obra de Whitman. Tal modificación quedó explícita en Redoble. Al inicio, la nación y Whitman asumieron a la guerra como una catarsis estadounidense necesaria. Después, la nación resurgiría poderosa, unida y verdaderamente democrática. Tal visión cambiaría después de 1862. En ese año, las batallas se volvieron más cruentas y Whitman tuvo contacto con la realidad del campo de batalla. La visión inicial cambió después de observar la realidad. Así, el poemario concentra una experiencia individual cambiante tanto de perspectiva como de entonación.

Este cambio de perspectiva fue explicado por Andrew Pearcy en su tesis Walt Whitman's Changing Perceptions of the Effects of the American Civil War and its Impact on his Poetry. En ese texto, los argumentos del autor muestran profundidad en esos cambios. Los primeros poemas en Redoble se llenan de patriotismo y validan las acciones de la guerra. Pero a la mitad del poemario, el tono de la poesía cambia a un optimismo anulado por los hechos durante conflicto. La mejor solución debía darse a través de la reconciliación democrática.

Las discusiones planteadas por estos autores guían el argumento de este capítulo: la experiencia del poeta durante el conflicto a partir del análisis de su obra. Apelo al análisis de los versos a partir de tres propiedades útiles para la historia: la descripción, la expresión y la evocación. Las creaciones de Whitman deben ser interrogadas a partir de los hechos históricos. Con esta tercia analítica pretendo elaborar una relectura de Redoble de tambor para observar los instantes escritos por el poeta sobre el conflicto, los cambios y los estragos de las hostilidades.

El último momento de la investigación, mi voz pretende discutir de manera directa con las ideas de los estudiosos de la poesía y la historia. Después de la vida y la obra queda la reflexión. Ahí aparece una pregunta clave para esta investigación: ¿qué es la poesía? Una 
pregunta difícil de responder, pero con un gran terreno por investigar. En el campo de la filosofía existen ensayos preocupados por la unión de literatura, poesía, historia, memoria y lenguaje. Alguien adentrado de lleno en esa problemática fue el filósofo Martin Heidegger.

En la conferencia intitulada "Hölderlin y la Esencia de la Poesía” (1973), el pensador orientó sus palabras hacia la validación de cinco argumentos para encontrar la esencia de la poesía: poetizar es la acción más inocente de todas; con el lenguaje, el hombre testimonia lo que es; la poesía abre el diálogo entre hombres y dioses; los poetas permanecen con/en lo que fundan; el hombre habita este mundo de manera poética. El filósofo indagó y se acercó a las propiedades de este acto creador.

En cada argumento, la esencia de la poesía se ata a una forma humana, a la del poeta. La imagen de éste sirve para aterrizar lo intangible en algo concreto: es-ahí. Para Heidegger no hubo una definición precisa de poesía. Él sólo intentó entender la "esencia esencial” de ella: la invención de un mundo a través de la existencia y del lenguaje de un hombre. La conferencia concluye con la valía del poeta para aterrizar lo propio de la disciplina intangible: buscar en las acciones y en la palabra humana un lenguaje creador.

Otro argumento a revisar, es el de María Zambrano (1996), Filosofía y poesía. La pensadora española aportó una definición-objetivo de la poesía: ser la sal de la tierra. Sin embargo, este bello y fértil concepto queda incompleto y ambiguo si la poesía no se ata de personaje. El elegido es el poeta, no puede ser otro. La poesía no puede andar a través de los filósofos, pues ellos se preparan para su muerte. El poeta, en cambio, es amante e hijo de la poesía. Ella lo crea y hace que él la necesite sin remedio.

Para Zambrano, la poesía busca de su propia supervivencia para seguir fertilizando la tierra. El poeta no puede renunciar a su creadora porque ella se transforma en él. Por su parte, el creador no busca morir y durante ese trayecto, ambos seres se fijan, se sueñan, se 
comparten. Cuando al creador de versos le llegue su muerte irremediable, la poesía podrá sobrevivir hasta encontrar a alguien más, a alguien con la capacidad de conducirla. Al final, ante los dominios de la muerte, no importa qué pase, siempre quedará la poesía.

No sólo los filósofos han escrito sobre los dominios de la poesía. Los poetas se han hecho y asido de ella. Una referencia obligada para esta investigación es Octavio Paz (1972). A partir de las letras del poeta mexicano, he podido nombrar esta investigación. El Nobel mexicano realizó todo un ensayo con el fin de definir y abordar a la poesía desde todas sus posibilidades. El arco y la lira concentra la voz de un gran poeta.

En su ensayo, Paz confirma la indefinición de la poesía. A lo largo de un párrafo de más de 20 líneas, otorgó bellas aproximaciones a un concepto, nada más. Después de esas oraciones, el libro está enfocado en demostrar el lugar de la poesía -sólo asible- en la extensión de un poema. Paz enfatizó en las propiedades en vez de una definición para ella: no todo poema es poesía y toda la poesía no puede caber en un poema. Con esta frase no hay un significado sino un abanico de opciones.

La capacidad del poeta toma protagonismo. Con base en este personaje y en su habilidad creadora, la poesía puede liberarse y habitar el lenguaje, los versos, las imágenes. Con estos elementos, el poeta revela a la poesía para después consagrar un instante. Al lograr esta acción, la poesía se entrega a la comprensión del mundo heroico, de la historia, de las sociedades y del pasado. La propuesta de Octavio Paz abarca la unión entre escritor, poema y poesía. La tercia es crucial para entender el peso de lo poético en la historia.

Aunque no hay una definición más allá de su nombre, la poesía crea vestigios desde sus propiedades. La evidencia poética de tiempos anteriores habita en los poemas. Alan Gillis (2014) argumenta, en "Poetry: An Introduction", que un poema se asemeja a un caleidoscopio de ideas contrastantes sobre lenguaje, arte, individualidad, realidad y/o una lista interminable 
de factores. Dentro de ese lugar, el lector de poemas no puede perder de vista, ¿quién escribe?, ¿sobre qué escribe?, ¿cuándo y dónde escribe? La poesía está destinada a recrear una experiencia individual y colectiva, mientras mantenga una relación entre inquebrantable con el lenguaje, la escritura y el hombre.

En el tercer apartado también planteo una pregunta clave: ¿cómo se ha utilizado la poesía en el terreno histórico? José Carlos Bermejo Barrera (2005) propone la capacidad creadora del lenguaje tanto en la poesía como en la historia. En el ensayo intitulado Sobre la Historia considerada como poesía, el historiador muestra una relación entre ambas disciplinas humanas. Tanto poesía como historia comparten una función poética capaz de describir, evocar y expresar. La tercia de propiedades también puede originar y formar parte de un discurso histórico.

En el ensayo, la historia y la poesía proyectan al mundo desde su ilusión e interés por actualizar la ausencia - la del pasado-. De esta manera, ambas disciplinas ofrecen una visión pura y neutral de lo sucedido. El par de disciplinas humanas deben compartir las tres propiedades del lenguaje de manera complementaria y no excluyente. Prescindir de alguna, o privilegiar excesivamente a una de las tres, ocasionaría que la historia y la poesía perdieran su naturaleza específica: transmitir conocimiento pasado.

Desde el terreno de la literatura, Facundo Ruiz (20017), "Poesía, historia y justicia en América Latina", indaga sobre la relación entre texto-autor, entre literatura-mundo. Esta relación pondera la pertenencia de todos los escritos, libros y poemas en una corriente literaria de tipo mundial. Para Ruiz, esto no es posible. La convivencia de relaciones teóricas, geográficas y políticas en un texto no pueden ser homogéneas. Nada responde a las mismas características. Si todos los poemas, ensayos o libros correspondieran a un mismo estilo, a 
un mismo universo, se omitirían las particularidades de cada escrito. Esto provocaría una estandarización de los temas y las discusiones.

Ruiz se opone a esta idea de generalización. Aunque él escribe desde la literatura, no minimiza el papel de la historia en su ensayo. El argumento refiere la existencia de una relación de retorno entre el poema y el poeta. El papel del escritor de versos es realizar, desde su pertenencia histórica, una evidencia de su razón creativa. Esta evidencia otorga una pertenencia histórica, una memoria, a su autor. Poema y poeta son un espejo reflejados entre sí. Ambos pueden crear un fractal de posibilidades y razones en respuesta a su historicidad. Es una relación inquebrantable que vincula al mundo, al lector y al texto.

Además de Ruiz y Bermejo Barrera, Jorge Silva Castillo (2017) puso la muestra de pensar a la poesía como parte de la disciplina del pasado. En Gilgamesh o La angustia por la muerte, tradujo el que es considerado como el primer poema conocido por la humanidad. No obstante, en el prólogo de este documento existen dos puntos a retomar y ampliar durante el trabajo: la poesía es la fuente originaria de conocimiento y es la encarnación de un prototipo social. Estas ideas son una guía para no perderse en el intento.

Señalar lo original de algo es una tarea complicada. La manera es cómo decirlo. Antes de las fuentes documentales como primicia para la historia, dos tipos de testimonios dominaban la hechura del pasado: la oralidad y la poesía. Esta última era el instrumento donde los hechos quedaban plasmados con una idea central, estructurada y sumamente detallada de los hechos. Para confirmar este argumento, hay que echar un vistazo a la primera epopeya de la humanidad. Escrita en verso, Gilgamesh ha aportado a todas las leyendas o mitos de la humanidad. La poesía origina patrones a seguir.

El segundo argumento de Silva pondera el papel del poema como la encarnación de un prototipo social. Esto va más allá de quién o quiénes escribieron el poema. El autor es 
relevante cuando expresa su individualidad en un tiempo y lugar precisos. El poeta no representa la experiencia de un individuo sino la proyección de la imagen que se hace de sí misma la sociedad. Babilonia pudo ser conocida y reconocida a través de lo plasmado en unas cuantas tablillas. El autor del poema épico es desconocido, pero la civilización pudo mantenerse en el imaginario de la humanidad.

En las publicaciones mencionadas existe una aproximación en colocar a la poesía como una fuente para la historia. Ella es parte central del trabajo, pero ninguno dice el cómo utilizarla para estudiar el pasado. Un trabajo, desde el punto de vista histórico, que ha intentado encontrar el punto de unión entre poesía e historia es: La sagrada experiencia: una revisión del "ser" en el tiempo y de la existencia del poeta Hafiz de Shiraz (ca. 1315-1390) (2017). ${ }^{1}$ En tal investigación, intenté crear un ambiente propicio para el uso de la poesía en la historia, mientras sucede una dialéctica filosófica alrededor.

En aquella investigación, abordé problemas filosóficos antiquísimos, inexplicables y a veces incomprensibles: el ser y el tiempo. Mi búsqueda arrojó un punto de convergencia, no de definición de éstos. El ser ata la presencia de un hombre en el mundo dentro de un tiempo percibido y nombrado. El tiempo se concibe como el movimiento del lenguaje y su vuelco hacia el terreno de la palabra. El ser y el tiempo hechos palabras pueden ser utilizados por los poetas para nombrar la realidad. Esto les da la característica para volverse parte de la historia.

En la parte histórica, esa investigación ahondó en la vida de Hafiz de Shiraz. Con base en los poemas de ese hombre pude indagar en tres aspectos de su existencia: el significado del sufismo, la manera de trascender lo humano y acercarse a Dios, y lo hechos que rodearon

\footnotetext{
${ }^{1}$ Ese trabajo resultó en mi trabajo de investigación final para obtener el grado de Licenciado en Historia. El documento fue presentado el 2017 en la Coordinación de Historia de la UAM Unidad Iztapalapa.
} 
a Hafiz durante su vida terrenal. En estos tres apartados, la poesía fue crucial pues dejaba ver la manera de actuar y de vivir del poeta. Las fuentes de este apartado no fueron sólo poemas. Un poema nunca está solo. Documentos sobre Irán en el siglo XIV, así como estudios sobre la vida del poeta me ayudaron a resolver los vacíos del pasado.

Veo oportuno recuperar las conclusiones obtenidas en la Sagrada Experiencia, así como las interrogantes surgidas en el presente estado de la cuestión. La poesía no ha sido utilizada en el terreno histórico a partir de la relación inquebrantable entre quién y dónde existe la poesía. De igual manera se ha omitido el valor de los versos como una fuente descriptiva, expresiva y evocativa de una postura del pasado. La poesía tiene en sí la habilidad de mantener e incitar el imaginario de la humanidad. Con base en estos supuestos, busco desarrollar una investigación cohesione lo poético en el estudio de la historia.

La poesía contiene conocimiento sobre el pasado. La historia debe verla como una evidencia más del hombre dentro de un tiempo-espacio preciso. Resguardada del poeta y su capacidad de capturar su cultura, individualidad, sociedad y época en un poema, la poesía también se convierte en un contenedor de información sobre un hecho. Su acceso al pasado debe suceder a través de la realidad y la obra de un autor. Allí radica su fuerza y utilidad para recrear un acontecimiento. 


\section{ANTES DE COMENZAR}

La reelaboración del ayer se vincula de manera directa e innegable con los métodos y las fuentes históricas. La poesía aporta información pues muestra una relación de doble vía con el pasado: tanto la dinámica de una sociedad desenvuelta en diversas coyunturas, como en coordenadas espacio-temporales precisas. Las letras no pueden arrancarse del ayer. La historia tampoco omite el vínculo poeta-poema-realidad como un contenedor de testimonios y acontecimientos. Atada del poeta, sus palabras y un texto, lo poético suma conocimiento e información.

Si lo poético ayuda a recrear un hecho, entonces también debe criticarse la información que contiene. Ahí radica la tarea del historiador: reunir para cuestionar la información brindada por la poesía. De esa manera, la historia surge desde la interpretación de las fuentes informativas. La poesía vinculada al poeta-poema-realidad queda plasmada en un documento existente con un contexto específico. Al ser pensado de esta manera, el historiador también puede cuestionarlo para obtener respuestas sobre algún suceso. Por estas razones, la poesía no puede despojarse de su capacidad reveladora de otros tiempos.

Esta investigación posee un objetivo principal: descubrir y revelar el valor de la poesía como una fuente de conocimiento histórico. La poesía parece un ente indefinible hasta que el poeta la toma y la transforma en una obra de arte para otorgarse al conocimiento histórico. Ahí el pasado puede estudiarla con base en los instantes poéticos, en el lenguaje. La poesía forma parte de la historia cuando sus palabras logran manifestar la capacidad linguiística de un hombre y de un hecho en específico. 


\section{Capítulo I}

\section{Destellos de vida: poeta-poema-realidad un vínculo inquebrantable}

The proof of a poet is that his country absorbs him as affectionately as he has absorbed it.

Walt Whitman

La grandeza de un poeta no se mide por el tamaño sino por la intensidad y la perfección de sus obras.

Octavio Paz

Como si lo natural fuera la errancia, el desasosiego, el hombre funda su esperanza en una búsqueda sin fin, la búsqueda del sí propio. Y es que el sí propio resulta tan difuso que diluye y planta al ser humano con una sobra ante el parapeto de sus reflejos.

Gloria Vergara

Walt Whitman (1819-1892) representa un baluarte para los Estados Unidos. Durante su vida y en sus poemas, proclamó la unión — simbólica y mutua- entre individuo, sociedad, espacio y contexto nacional. Persona y obra respondieron al imaginario sociocultural e histórico de su nación para instaurar la idea del "yo" como base de unidad: yo con la naturaleza, yo con la democracia, yo con el país, yo con los demás. En el prefacio de Hojas de hierba (1855), Whitman concluyó que la prueba máxima para un poeta radica en ser absorbido por su país de manera afectiva y recíproca.

El primer capítulo de esta investigación utiliza la conclusión hecha por Whitman: resaltar la utilidad histórica de una relación inquebrantable: poeta-poema-realidad. Con su idea del "yo", escribió versos donde testimonió tanto su existencia como la de otros. Abrió un diálogo entre hombres y dioses donde brindó de permanencia a las palabras. ${ }^{2} \mathrm{El}$ poeta

\footnotetext{
${ }^{2}$ En la conferencia intitulada "Hölderlin y la esencia de la poesía", Martin Heidegger (1973) desarrolló esta idea nombrándola como la esencia esencial de la poesía. Para el filósofo alemán había cinco características innatas para entenderla. Uno, poetizar es la acción más inocente de todas. Dos, con el lenguaje, el hombre testimonia lo que es. Tres, la poesía abre el diálogo entre hombres y dioses. Cuatro, la humanidad permanece con/en lo que funda. Cinco, el hombre habita este mundo de manera poética. la poesía y la figura del ser humano. En esta unión, ninguno pierde sus características. Más bien ambos se sujetan, se corresponden y se ajustan a sus propias necesidades (pp. 105-124).
} 
unió su lenguaje con los hechos a su alrededor. A través de su obra puede enriquecerse y sustentarse la comprensión de sucesos personales y nacionales.

La temporalidad recae en algunos momentos de la vida de Whitman: desde su nacimiento hasta la conclusión de la Guerra Civil (1819-1865) Esa duración contiene vivencias personales y familiares, así como elementos culturales y sociales adaptados en la obra del poeta —su niñez, problemas familiares, educación, labores periodísticas, además de distintas situaciones nacionales-. El análisis histórico de esos años puede vincular al individuo, la poesía y la nación.

Después de las hostilidades, Whitman alcanzó un punto de no retorno. En 1865, sus letras expresaron lo que deseaba comunicar; alcanzaron la cúspide de su genio literario. Si bien sus primeras creaciones no lo llevaron a conquistar la cumbre, la edición posterior al conflicto complementó y actualizó los logros del escritor. Por esta razón, el capítulo no abarca toda una vida, sino los momentos donde se observa y se reconoce la individualidad, el proceso intelectual de su obra, la vida nacional, así como la interacción entre ellos.

La investigación inicia con la existencia e intelecto de un hombre en tiempo y espacio preciso. Whitman ciñó su obra y su papel como poeta, al entramarla con diversas situaciones nacionales. Absorbió su entorno para sustentar su voz ante los hechos. Los momentos seleccionados rastrean experiencias para recrear un fragmento en la historia del individuo, así como en los hechos ocurridos en los Estados Unidos. Así busco demostrar la utilidad histórica de la relación entre el hombre, el pasado y sus creaciones.

Entre todas las naciones, los Estados Unidos necesitan de los poetas que se precien de poseer una poderosa fuerza poética. Indudablemente la tendrán y la utilizarán hasta niveles jamás alcanzados. Sus presidentes no serán el punto de referencia más común, sino los poetas. De entre toda la humanidad, el gran poeta se sitúa como centro de identidad e igualdad [...] (Whitman, 1855). 
La comprensión del mundo siempre estará a merced de quien la nombra. Aunque esta investigación corre el riesgo de generalizar u omitir información, también busca entender la existencia del sujeto, su creatividad poética y la historia de los Estados Unidos. La idea presentada por Whitman no parece ajena: la reciprocidad entre individuo, poema y nación tiene una base en el "yo". Por estas razones, la poesía y la realidad deben mediarse a través de la vida del poeta.

Poeta, obra y patria deben fluir como olas en el océano. A partir del escritor es posible conocer su individualidad, su obra, su país, así como la interacción entre ellos. La existencia de Whitman es donde parte esta investigación. Él fue conocido de distintas maneras: el poeta gris, el poeta de la democracia, el enfermero, el voluntario, el padre del verso libre. Su obra promovió y creó los ideales estadounidenses en el siglo XIX. Whitman creyó en la poesía como un criterio decisivo para forjar una identidad nacional.

Sobre este poeta se ha formado un acervo impresionante. Cada uno de los artículos, libros o ensayos invitan a conocerlo y reconocerlo a partir de sus cualidades humanas, su naturaleza o su talento artístico. Ed Folsom (2019) recopiló los títulos sobre el tema Whitman. Más de 70 autores, sólo ese año, pusieron bajo la lupa algunos aspectos conocidos o desconocidos. Esas publicaciones muestran el interés de indagar sobre el poeta desde distintos puntos de vista: análisis históricos, literarios, sociales o culturales.

La presencia de Whitman continúa vigente en el imaginario cultural estadounidense e internacional. En la revista Walt Whitman Quarterly Review, ${ }^{3}$ supervisada por el mismo Folsom y editada por la Universidad de Iowa, existen más de mil artículos sobre su vida y

\footnotetext{
${ }^{3}$ The Walt Whitman Quarterly Review se fundó en 1983. Sin embargo, esta publicación se considera la sucesora y heredera de dos revistas creadas a lo largo del siglo XX: Walt Whitman Review y Walt Whitman Newsletter. Ed Folsom a partir de 1990, ha sido el editor en jefe de esta publicación. La revista está disponible en línea [https://ir.uiowa.edu/wwqr/]. Recuperado en julio-agosto de 2020.
} 
obra. Los escritos van desde comparaciones literarias, el morbo de su vida sexual o la puntualización de algún momento en su existencia. A pesar de la vastedad, las preguntas siguen apareciendo.

Ante la vastedad, deben encontrarse coincidencias y referencias. Mi intención apunta a demostrar la unión simbólica y mutua del poeta, su obra y su realidad. Con base en esta idea, el libro realizado por David S. Reynolds (1995), Walt Whitman's America, a Cultural Biography, se desarrolla a través de la existencia del poeta, así como del análisis de los hechos nacionales que influenciaron su obra. El autor cubre cada uno de los resquicios en la vida de Whitman. Concibe el microuniverso donde el poeta habitó y sustentó sus poemas con ayuda de la historia nacional estadounidense.

Para Reynolds, historiador y crítico literario, los estudios literarios se enfocan únicamente en los elementos retóricos; profundizan en la dimensión individual, pero omiten el contexto del autor. En cambio, su libro da un giro a la lectura y a los trabajos sobre Whitman: no hace a un lado la vida del poeta, ni la de la nación norteamericana. Al contrario, entendió al individuo y a sus creaciones a través de la sociedad y el entorno nacional. Mi investigación comparte los objetivos con esa biografía: concentrar un esfuerzo de convivencia entre el personaje, la obra, un tiempo y un espacio.

Del trabajo de Reynolds pretendo retomar la intención de unir históricamente la existencia y la obra del poeta. Ninguno de esos aspectos debe quedar alejado uno del otro. Gracias a esta información, puede verse al escritor de manera ambivalente: ser admirado u objetado a causa de ciertas actitudes; sin embargo, éstas deben ser juzgadas desde la perspectiva histórica y no desde los juicios del presente (Reynolds 1995). Busco vincular la historia estadounidense, la literatura y la vida del poeta. 
Jerome Loving (1999), por otra parte, enfatiza en los motivos del poeta para realizar sus poemas. Walt Whitman: The Song of Himself, y a diferencia de lo hecho por Reynolds, parte de una pregunta central: ¿qué sucedió con Whitman tras publicar la primera edición de Hojas de hierba, en 1855? Ese trabajo recrea con meticulosidad algunos momentos de la existencia del escritor: su relación con Ralph W. Emerson, su gusto por la ópera, su etapa de empleado, así como sus lazos familiares. Cada uno de estos episodios mantiene una relación directa con las creaciones poéticas.

Loving notó los límites de su investigación: los poemas pueden coincidir con ciertos hechos encontrados en otras fuentes. Observar las creaciones poéticas sirve hasta cierto punto para descubrir otro tipo de registros e información: "El biógrafo busca en los poemas la vida no registrada del poeta" (Trachtenberg, 2000, p. 125). Aunque la discusión del autor se origina en la obra de Whitman, otras fuentes no son ajenas del todo. Ese estudio biográfico vale por la intención de esbozar sobre la utilidad de la poesía -si se sabe interpretar y leerpara recrear el pasado.

Mi investigación tampoco aborda toda una vida a detalle. Más bien brinda un panorama de los momentos de lucidez del poeta. Whitman, no dejó de escribir después de la guerra. No obstante, la cima de su poesía se dio durante los años de hostilidades. Para Loving, la Guerra Civil, por ejemplo, es un apartado relevante. El paso de Whitman por los hospitales mermó su salud, pero dichos episodios motivaron sus letras. La historia de vida no sólo apunta a la extraordinaria voz poética, sino también a instantes de dolor, sufrimiento y vulnerabilidad. Debe explorarse al escritor, a las regiones ocultas en su pensamiento, mientras aspectos culturales, políticos y sociales se leen entre líneas.

En lengua castellana, existe el trabajo de Félix Martín (2003). Con un título directo, Walt Whitman, el autor retoma señalamientos anteriores y posteriores de los trabajos ya 
analizados, así como de varias biografías más. El argumento presume simpleza: tratar de encontrar la personalidad y la parte humana de Whitman. Si Loving presenta la vocación poética y Reynolds relaciona lo público y lo privado del individuo y la nación, Martín muestra la parte introspectiva del escritor.

En cada episodio, Martín sintetiza los hechos más relevantes en la vida del poeta. Fiel a su idea principal, observa al personaje desde una perspectiva humana, a partir de sus actitudes: ensimismado, sexual, triste, preocupado, alegre, optimista, cambiante. Su discusión retoma lo escrito por otros autores, pero muestra las palabras del propio Whitman guardadas en cartas, poemas o prensa. Ese estudio muestra a la persona por encima del genio creador.

Cuando Martín se refiere a la parte humana es porque puntualiza acciones, sentimientos, ideas y decisiones. En 1860 y después de haber editado por tercera ocasión sus Hojas de hierba, Whitman cayó en un naufragio personal. Durante dos o tres años, sus pasiones lo alejaron de las letras, pero fundaron sus intenciones creativas para resaltar el amor, la vida, la muerte, la camaradería. El amor entre los hombres (adhesiveness) debía atraer todos los elementos reales e imaginarios del panorama nacional.

El amor debía sustentarse en la camaradería, la cual podía funcionar como vehículo para lograr los ideales nacionales. El sentimiento sobrepasaba las barreras fisiológicas y psicológicas de lo pasional. Whitman pensaba más allá de lo que sugiere esa palabra. Él recuperó la idea platónica del amor: ser el medio de los hombres para alcanzar un fin común. Una creencia entusiasta para amalgamar aspectos sociales y políticos en los Estados Unidos (Martín, 2003). El autor hace hincapié en la parte humana intelectual e íntima del poeta. Esas características también deben presentarse en mi investigación. 
En el archivo digital Walt Whitman, ${ }^{4}$ Ed Folsom y Kenneth M. Price (2007) lograron crear una sección dedicada a la vida del poeta. De manera cronológica y puntual, episodios icónicos son revisados y contrastados con otras biografías. Esos breves escritos carecen de profundidad: la mayoría tienen una extensión de tres o cuatro párrafos. Los trabajos ya discutidos pueden cumplir esa función de mejor manera. A pesar de la brevedad, el punto a favor recae en el conocimiento eficaz del poeta. Al no profundizar, los autores dejan abierta la necesidad de indagar.

Folsom y Price argumentan, por ejemplo, sobre el misterio reflejado en Whitman y sus creaciones. Ellos cuestionan si el poeta experimentó algún tipo de iluminación espiritual creadora de un tipo de poesía radical; o si su trabajo significó una estrategia para combinar periodismo, oratoria $\mathrm{u}$ otras fuerzas culturales para forjar una voz estadounidense innovadora. Más allá del misticismo, los biógrafos ven a Whitman con la intención de registrar y arraigar un ideal de unión en los Estados Unidos.

Ambos autores no niegan a Whitman como un poeta de inspiración y genio distintos. Pero también lo colocan al nivel de artesano, pues fue precursor del verso libre para conjuntar experiencias personales con la vida nacional: "su vida la agregaría, eliminaría, fusionaría, separaría y reorganizaría poemas mientras publicaba seis ediciones muy distintas de Hojas de hierba" (Folsmom y Price, 2007). Al no desprenderse de su contexto, coincido con la visión de los autores: Whitman no intentó ser místico, sino artífice. No sólo le dio voz a su nación, también resaltó objetivos en común.

Lo discutido abre la puerta hacia la vida y la obra del poeta. Con ellas busco entender la existencia de Whitman, su obra, y de algunos fragmentos en la historia de los Estados

\footnotetext{
4 (WWA) a partir de ahora.
} 
Unidos. Intento demostrar la relación inquebrantable entre poesía e historia mediada por la presencia del poeta. Mi trabajo recupera la conclusión hecha por Whitman: entender al individuo y la realidad nacional con base en una relación recíproca. Un poeta se inserta en una trama social concreta donde desarrolla su capacidad creativa. Él plasma en sus poemas información valiosa sobre algún hecho histórico.

El poeta significa la relación entre realidad y lenguaje. Crea un poema que resulta y depende de las distintas exigencias de cada época, del ambiente cultural y de la idiosincrasia del autor. A pesar de las variantes, el poeta se adueña de su tiempo-espacio y lo recrea a través de palabras, de instantes. Ese resultado adquiere una fuerza interpretativa individualcolectiva de una realidad. Como tal, puede servir para entender los hechos sucedidos en algún momento en el pasado.

Mi investigación comienza con la vida de Whitman. La comprensión de los hechos debe defenderse al resaltar su vida y su obra. A la vez, sus poemas enriquecen al pasado cuando tornan visibles idiosincrasias tanto individuales como colectivas. Esos documentos también muestran la manera de percibir, actuar y posicionarse ante las dinámicas y los hechos. Repito a manera de conclusión: la relación entre poesía e historia se encuentra mediada por el poeta mismo. Él se inserta en una trama social para consagrar realidades.

\section{Familia y nación: observar la realidad}

Walt Whitman perteneció a una de las primeras generaciones nacidas en los recién formados Estados Unidos. Nació en West Hills, Nueva York, en 1819, un lugar ubicado en la parte central de Long Island, a unos cuantos kilómetros de Brooklyn. Aquel sitio de ambiente campirano y relajado contrastaba con el incipiente crecimiento de las urbes neoyorkinas. El jefe de familia, Walter Whitman padre, dedicaba su vida a la carpintería o a las actividades 
en su propia granja. La madre, Louisa Van Velsor Whitman, se encargaba de las labores del hogar. Tanto la realidad nacional, como la familiar determinaron la trayectoria personal y creativa del poeta.

Pertenecer a aquella nación emergente significaba un orgullo desenfrenado para Walter Whitman. A sus primeros tres hijos los bautizó como Jesse, Walter -Walt, para diferenciarlo de él- y Mary Elizabeth, nombres de tradición familiar, de antepasados asentados en las trece colonias antes de la independencia en 1776. Para identificar a sus tres hijos varones posteriores, recurrió a los héroes de la Revolución y la Guerra de 1812: Andrew Jackson Whitman, George Washington Whitman y Thomas Jefferson Whitman. Solo el hijo menor, Edward, quien tenía una discapacidad mental y física, llevaba un nombre ajeno a la historia de la familia o a la del país.

En contraste a ese sentimiento patriótico, Walter Whitman gozaba de una economía inestable: cambiante y dependiente de las actividades diarias. Era un hombre sin suerte, ni con grandes habilidades para los negocios. Sus recursos los obtenía mediante actividades prontas y poco duraderas. Su trabajo como carpintero era intermitente y cuando no existían oportunidades para trabajar con la madera, se dedicaba de lleno a las labores en la granja (Folsom y Price, 2007). Los primeros años de Walt sucedieron rodeados de carencias y con un padre sumergido en el fracaso de sus finanzas vacilantes.

Incluso, sus primeros cuatro años fueron intensos e infelices (Reynolds, 1995). Además de las carencias económicas, Walter Whitman era un hombre severo, de mal genio y con un problema grave de alcoholismo. Walt lo respetaba, aunque nunca sintió un gran afecto por él. Su madre, por el contrario, significó un pilar emocional durante toda su vida. Con ella, tuvo un vínculo afectivo el cual quedó plasmado en una correspondencia recíproca 
y abundante. Su niñez se influenció por un par de figuras contrastantes: un padre adicto y fracasado, así como una madre idealizada.

Walt escribió infinidad de versos referentes a su madre. Con sus palabras creó una densa capa de elogios que vuelve difícil visualizarla. La verdadera Louisa Van Velsor no sólo hacía una analogía a la virtud y a la perfección: atractiva, vivaz, imaginativa, buena ama de casa, dadora de paz. También tenía un rostro oculto: idiosincrática, de fe cuáquera, a veces quejumbrosa, nerviosa e hipocondriaca. A pesar de las ambivalencias, su hijo siempre la recordó como una buena narradora de historias, con el don de la personificación y un gusto literario exquisito (Reynolds, 1995). La figura materna difería radicalmente del jefe de la familia.

Walt tuvo una relación desigual con sus padres, aunque como pensó Martín (2003), “ellas fueron más normales de lo que desearían algunos curiosos de la psicocrítica” (p. 15). Admiraba a su padre y a su habilidad como carpintero y hombre de granja. De él absorbió su filosofía y sensibilidad patriótica. De su madre desarrolló una percepción moral y positiva, además del gusto por la literatura. Ella mostraba un rostro incansable, espiritual, amoroso. Esas percepciones pueden leerse en el poema "Érase un niño que salía cada mañana". ${ }^{5}$ En ese texto, el poeta evocó la relación con sus padres, así como una de las tantas posibles estampas durante su niñez:

[...] La madre, en casa, poniendo en silencio los platos en la mesa para cenar;

La madre, de palabras afables, cofia y camisón limpios, que huele tan bien al pasar;

El padre, fuerte seguro de sí mismo, viril, mezquino, iracundo, injusto, El golpe, la palabra airada, el acuerdo estricto, la persuasión artera,

Las costumbres familiares, el lenguaje, la compañía, el mobiliario, el corazón henchido y anhelante, el afecto que nunca será desmentido,

El sentido de la realidad, la sospecha de que todo pueda ser, a la sazón, irreal, [...] (Whitman, 2019, versos 22-27)

\footnotetext{
${ }^{5}$ Poema publicado durante la vejez del poeta, en una de las últimas ediciones de Hojas de hierba, ca. 1871.
} 
Las situaciones y actitudes familiares poseen fundamento y explicación en el contexto sociopolítico, económico y cultural de los Estados Unidos. En el mismo año del nacimiento del poeta (1819) sucedió un pánico financiero. Este fenómeno marcó el inicio de un nuevo tipo de organización política y económica (Reynolds, 1995). Los pequeños productores como Walter Whitman no podían sostenerse de sus actividades temporales e inestables. Por otra parte, sus creencias políticas debían cimentarse en nuevas propuestas. La situación nacional, así como sus consecuencias, influenciaron de manera directa a la familia y a la vida de Walt durante sus primeros años.

En términos políticos, "la era de los buenos sentimientos" (The ERA of Good Feelings) se aproximaba a su fin (1787-1828). Las diferentes opiniones sobre el gobierno federal crecieron. Al existir el Partido Federalista como única fuerza, la toma de decisiones nacionales provocó la discordia entre líderes y pensadores. Muchos de ellos creían que el gobierno debía luchar y servir por el bien común; aunque no había una definición clara sobre el significado de ese concepto (Locks, et al, 2007). Los embates contra esta etapa política anunciaban reformas de fondo al sistema político de los Estado Unidos.

Esos cambios ganaron velocidad a partir de la depresión. Desde una perspectiva general, la población no sentía confianza, ni aprobación, en el gobierno y la élite privilegiada. Una nueva generación de políticos populistas, alimentados por los resentimientos y los sueños de la clase trabajadora, emergió en 1819. El temperamental Andrew Jackson -el primer candidato presidencial sin origen noble o elitista- obtuvo la aprobación de la clase obrera. Constructores, artesanos, carpinteros o granjeros, llenos de mala suerte, como Walter Whitman, formaron la base de la política jacksoniana. (Reynolds, 1995). La crisis ayudó a crear otra perspectiva del sistema oficial norteamericano. 
Esas modificaciones se ubican en un periodo de sobresaltos e incertidumbre, aunque también de logros y crecimiento sociales. El entusiasmo religioso -bautistas, metodistas, mormones, así como iglesias de afroamericanos - tuvo su auge. Por otra parte, los cambios sociales, surgidos desde el esfuerzo de la clase trabajadora, inspiraron movilizaciones, rupturas y proyectos de reforma. La oposición intentaba construir, desde una postura radical, “[...] los cimientos morales para estabilizar un mundo desordenado." (Pani, 2016, p. 88). Individuos y comunidades aspiraban a materializar otro tipo de ideales, en conjunto, para así oponerse a la tradición de los buenos sentimientos de unos cuántos.

En términos económicos, el pánico se cataloga como la primera depresión moderna —o de corte capitalista- en los Estados Unidos (Pani, 2016). Mientras el papel moneda estadounidense se inflaba, los precios mundiales de las materias primas colapsaron. La población tenía un desencanto con el papel moneda. Esto provocó que las personas trataran de rescatar un poco de su dinero retirándolo de las instituciones bancarias. Acto seguido, bancos y pequeños negocios quebraron; el desempleo y la miseria se generalizaron. La zona urbana se devastó, mientras en el área rural, los padres no podían brindar abrigo ni alimento a sus hijos. Eran tiempos difíciles en todas las regiones de los Estados Unidos.

Tanto la vida urbana como la rutina en el campo se vieron afectadas. Los pequeños productores, del Norte y del Sur, sufrieron los estragos del pánico. La recuperación llegaría después de ese tiempo de la mano de la manufactura a pequeña escala. Tiendas, bancos, fábricas, así como trabajadores independientes - herreros, zapateros, sastres, granjeros, pintores y carpinteros- buscaban su sustento a pesar de la dificultad de la situación (Rothbard, 2007). Aunque el fenómeno económico duró cinco o seis años, sus estragos duraron lo suficiente para afectar, de maneras distintas, todas las latitudes del país. 
Las consecuencias se vivieron desde diversas perspectivas. Los agricultores asentados lejos de los grandes puntos estratégicos y comerciales resintieron el nulo intercambio comercial. Los residentes urbanos no encontraban trabajo. En Filadelfia, por ejemplo, el 75 por ciento de los trabajadores permaneció inactivo. El número de indigentes aumentó al igual que los deudores encarcelados por falta de pago. Las personas sin casa propia dejaron de creer en la tenencia de una. Los terratenientes rurales, incluso los considerados acomodados, tuvieron dificultades para pagar sus deudas bancarias (Locks, et al, 2013).

La mayoría de los observadores interpretó estas conmociones y conflictos como los inevitables dolores de crecimiento de la que estaba destinada a convertirse en una gran nación (Pani, 2016, p. 89).

Desde sus primeros años de vida, Walt Whitman se entramó de manera directa con la situación familiar, así como con los hechos político-económicos estadounidenses de las primeras dos décadas del siglo XIX. Aunque era muy pequeño, la realidad cimbró la cotidianeidad campirana de su familia. El pánico ocasionó un enfrentamiento real entre las familias con sus finanzas quebradizas. Estos grupos tenían dos opciones en su horizonte: trasladarse a otros lugares para obtener mayores oportunidades - de cualquier índole $-o$ anclarse a la escasez. Las opciones se redujeron. El cambio de un lugar a otro se convirtió en la constante para las familias como la del poeta.

Los Whitman poseían recursos contados. El jefe de familia luchó contra sus adicciones, así como contra las pocas oportunidades de la realidad nacional. Un tiempo se dedicaba a la carpintería y otro a la agricultura, pero la inestabilidad financiera lo obligó a tomar decisiones. Cuando Walt estaba a punto de cumplir cuatro años, decidió mudar a su familia a la creciente ciudad de Brooklyn, sitio emergente como el principal centro urbano de la nación (Folsom y Price, 2007). El desempleo y la miseria coincidieron con las necesidades de los Whitman por obtener un lugar donde asentarse y sobrevivir. 
En mayo de 1823, la familia se trasladó a Brooklyn, Nueva York. Esa ciudad fue el puente cultural y económico entre el bullicio de Manhattan y la calma provincial de West Hills. La vida urbana, en la segunda década de siglo XIX, parecía simple y cruda; lucía primitiva y hasta olvidadiza. El agua se obtenía de las tomas en la calle; la religión dominaba la cotidianeidad; el tren llegaría hasta la década siguiente, y con él, la vida industrial (Reynolds, 1995). En ese lugar, los Whitman encontraron un sitio de mediación entre carencias y oportunidades. Ahí también, pueden rastrearse los primeros pasos en la formación y la niñez de Walt.

Brooklyn se encontraba en un despertar cultural y económico. La familia llegó a la urbe para encontrar un punto medio entre la ciudad y la zona rural. A Walt le encantaba vivir cerca del East River, donde de niño pudo viajar en ferris de ida y vuelta a la ciudad de Nueva York. De ahí absorbió una experiencia relevante durante toda su vida: amaba ese tipo de embarcaciones tanto como a la gente que trabajaba en ellos. En su poema "El ferri que cruza Brooklyn” exploró la resonancia completa de esos viajes (Folsom y Price, 2007). La ciudad significó un lugar bello y dador de oportunidades culturales.

La observación y el disfrute de los alrededores comenzaron a ser una actividad constante para Walt. Aquel poema, según Howard (1998), no habla sobre las razones del poeta para cruzar el río, sino del propósito de absorber y entramarse con el espectáculo del paisaje: el agua, la gente, el sol poniéndose, los barcos, los muelles y una ciudad a la distancia. Ese texto describe la experiencia diaria de un viajero del siglo XIX. Al mismo tiempo, muestra una profunda meditación sobre el viaje, el tiempo y el cómo existe el ser humano dentro y fuera de ellos.

Ellos y todo lo demás eran para mí lo mismo que para ti, Amé bien esas ciudades, amé bien el río majestuoso y veloz, Los hombres y las mujeres que yo veía tan cerca de mí, 
Otros son los mismos, otros me miran porque yo los esperaba con ansias,

(El tiempo llegará, aunque me detengo aquí hoy y esta noche)

(Whitman, 1856, versos 49-53).

La creciente urbe fue un punto donde se asentaron los neoyorquinos incapaces de despojarse de la vida provinciana. Aunque en los primeros años del poeta, la estabilidad parecía inexistente - pues los Whitman ocuparon siete casas a lo largo de diez años-, en la ciudad recibió una educación inicial la cual completaba al visitar museos, teatros, conferencias y bibliotecas. Además, su niñez transcurrió entre festivales, desfiles, lecturas o funerales (Martín, 2003, p. 16). La vida campirana no ofrecía ninguno de esos paisajes. Brooklyn representó el punto para crecer intelectual y económicamente, sin abandonar la quietud del campo.

Tal y como lo describió el mismo Whitman (en Reynolds, 1995): "En la segunda década del siglo XIX, Brooklyn parecía una enorme granja en comparación a como luce ahora -en los años 60-" (p. 31). Cerdos y pollos se confundían entre la multitud. Las calles sin pavimento se convertían en lodazales durante el invierno. La calle Fulton era la única iluminada con lámparas de gas. En las demás, la gente debía cargar sus propias linternas, tal y como lo hacen las luciérnagas en medio de la penumbra. Además, las condiciones sanitarias carecían de excelencia. El cólera atacó constante a la población de aquel sitio. A pesar de las dificultades, Walt forjó una capacidad de entender y mirar a su entorno.

Las memorias de Walt se mezclaron en la realidad. Su rutina estaba en la urbe, pero su atención se dirigió a los paisajes rurales. Vivía un idilio al salir de Brooklyn para visitar a sus abuelos en Long Island, donde realizó viajes constantes, además de recorrer sus costas. Ahí se vinculó con el paisaje de la isla; observó el misterio cuando el agua se vuelve una con la tierra, donde las corrientes se fusionan con la arena. Los instantes de su niñez desarrollaron 
una capacidad de observar la magnificencia del paisaje y la realidad familiar y nacional. De niño, Walt Whitman no escribió versos; aunque en poemas de años posteriores, recreó las postales adquiridas durante su infancia.

$[\ldots]$

Traído aquí con premura, antes de que todo se escapara,

Hombre ya, aunque, a juzgar por estas lágrimas, niño otra vez que se tira a la arena y enfrenta a las olas,

Yo, cantor de dolores y alegrías, unificador del aquí y del más allá,

Me sirvo de todas las señales para usarlas, pero superándolas enseguida,

Canto un recuerdo.

Una vez, en Paumanok,

Cuando el aroma de las lilas llenaba el aire y crecía la hierba del Quinto mes,

Había en los escaramujos de esta costa

Dos visitantes alados de Alabama, los dos juntos,

Y, en su nido, cuatro huevos de color verde claro con motas pardas,

Y todos los días la hembra se acomodaba en el nido, sin piar, con los ojos brillantes

Y todos los días yo, un niño curioso, sin acercarme demasiado, sin molestarlos nunca,

Los observaba cauteloso, los absorbía, los traducía.

[...] (Whitman, 1860, versos 18-30)

\section{La juventud: volverse parte de la realidad}

La toma de decisiones marcó la juventud de Walt Whitman. Para 1830, la inestabilidad económica familiar, además del menosprecio de sus profesores por no augurarle un futuro brillante, lo forzaron a dejar la escuela pública para trabajar como ayudante de James B. Clarke. Ese abogado lo remuneraba poco, aunque le otorgó una suscripción a una biblioteca circulante en Brooklyn para compensar el pago. Walt, con once años de edad, comenzó una educación autodidacta además de ecléctica. Sus lecturas las complementó con visitas a

\footnotetext{
${ }^{6}$ Véase el poema "Out of the Cradle Endlessly Rocking”. En cierto nivel y comprensión, estos versos guardan momentos de la niñez de Whitman durante sus paseos en la costa de Long Island. De hecho, este lugar es una constante en este poema citado. Así también se puede corroborar el argumento del idilio del poeta con el paisaje y la tranquilidad ofrecida por la vida rural y por la costa.
} 
museos, conferencias y debates. Con tales recursos, su formación sucedió en medio de despachos, litigios, conferencias y libros.

Walt llevó a cabo un plan de estudios propio. La literatura, además del teatro, la historia, la música y la arqueología, le abrieron un camino de aprendizaje avanzado. Algo muy distinto a la educación recibida por los intelectuales de su tiempo, quienes gozaban de una instrucción estructurada en instituciones privadas. En aquellos días, el joven leyó las obras de James Fenimore Cooper, Walter Scott, Las mil y una noches, así como otras historias (Folsom y Price, 2007). Si bien sus responsabilidades habían cambiado, el ambiente laboral lo mantuvo en una dinámica intelectual frenética.

Walt mudó el mundo de las leyes por una actividad trascendental y definitoria: las tareas editoriales. Desde 1831 y durante un par de años trabajó como aprendiz en una imprenta. Se familiarizó con la hechura de los periódicos Long Island Patriot y Long Island Star. Para el verano de 1833, el joven debía considerar las dificultades de su entorno: el cólera había causado 35 muertes en Brooklyn y la situación económica familiar se afectó —otra vez- por los reveses económicos de su padre. La familia regresaría a Long Island, no a West Hills, sino a Hempstead (Reynolds, 1995). El joven de 14 años no secundó la decisión de su padre. Nadie mermaría su interés por las letras y los diarios.

Solo en la urbe, Walt aguzó su capacidad de observación. La vida urbana brindaba oportunidades no encontradas en el ambiente rural. Por ejemplo, en el mismo 1833, sucedió la visita presidencial de Andrew Jackson a Brooklyn. "Walt vio a un viejo enjuto, de pelo blanco peinado hacia atrás, de rígido rostro curtido por el clima, quien llevaba puesto un sombrero hecho con piel de castor blanco, mientras las multitudes le aplaudían cuando atravesaba la ciudad en su propio carruaje" (Reynolds, 1995, p. 49). La estancia citadina le permitió mirar más allá de los paisajes; pudo absorber aspectos de la vida nacional. 
Además de la apariencia física, Walt Whitman admiró en Jackson su capacidad de liderazgo. Aunque también pudo ver las dos caras opuestas y contradictorias del dirigente del país. Uno de esos rostros representaba la igualdad; el presidente otorgaba voz a las masas. Por otro lado, Jackson arraigaba un rostro tirano y déspota, el cual utilizó para controlar la política estadounidense por casi dos décadas. Según Reynolds (1995), “la ambivalencia demostrada por el político influyó de manera directa en la escritura de Whitman en años posteriores" (p. 49). El poeta también demostraría una ambivalencia plasmada en su obra.

El poema "Yo, imperturbable" enseña la dualidad adquirida durante los años 30. En el verso inicial, el protagonista del poema, el "yo", aparece totalitario, señor de todo, paciente ante la irracionalidad de su alrededor. Después, el tono gira a conciliar. Su protagonismo se funde en las distintas realidades de la nación. Ya no existe la exclusión, sino la unión con el entorno y con cada habitante de la tierra. La tiranía del "yo" se adapta para pertenecer a cualquier forma de vida y entorno. En ese poema existe una dualidad iniciada en el absolutismo, pero adherida a la concepción de un todo:

Yo, imperturbable, plantado en la Naturaleza, Señor de todo o señora de todo, sin perder el aplomo en esta turba de cosas irracionales, Imbuido como ellas, pasivo, receptivo, silencioso como ellas, Descubriendo que mis ocupaciones, mi pobreza, mi notoriedad, mis flaquezas, mis crímenes, son menos importantes de lo que creía

Yo, frente al mar de México, o en Mannahatta o Tennessee, o al norte o en tierra adentro,

Hombre ribereño, o de los bosques, o de cualquier forma de vida campesina en estos Estados, o costero, o lacustre, o de Canadá;

Yo, dondequiera que mi vida, impasible ante las contingencias, Enfrentándome a la noche, a las tormentas, al hambre, al ridículo, a los accidentes, a los desaires, como hacen los árboles y los animales. (Whitman, 2019, pp. 126-127).

Tal y como Jackson, Walt Whitman escribió desde posturas contrastantes. Creó versos potentes para llegar a las masas. Su intención apuntaba a ser leído y entendido por cualquier lector. "Canto el yo, una simple persona, un individuo; / sin embargo, pronuncio la 
palabra Democrática, la palabra En Masse.” (Whitman, 2019, p. 103). Del otro lado del discurso, hay rastros de un poeta totalitario y déspota: "La presencia del más grande poeta conquista”, “Lo que yo asumo, tú lo debes asumir” (Reynolds, 1995, p. 49). En los años 30, Walt miró su entorno, los hechos y los líderes de su nación. Su poesía, años más tarde, reflejaría estos episodios de absorción.

Establecerse en la urbe le permitió no sólo ser un observador, sino un participante de la realidad. A pesar del riesgo sanitario y la lejanía familiar, Walt se mantuvo en Brooklyn sumergido en letras y noticias. Incluso, publicó su primer trabajo como periodista, en noviembre de 1834: "El tiempo de antaño" ("The Olden Time”). Un artículo de tres párrafos donde el joven escritor hablaba de los cambios en Nueva York. En aquel tiempo, la ciudad lucía civilizada, aunque aún existían habitantes que veían y pensaban a la metrópoli como una aldea pequeña (Whitman, 1834). Con 15 años, Walt abrió la puerta de su carrera como periodista.

Para 1836, el joven continuaba inmerso en la impresión y creación de periódicos. Su rutina avanzaba alentadora hasta que, en ese mismo año, un par de incendios destrozaron el distrito de talleres e imprentas donde trabajaba. El fuego arrasó con sus logros incipientes. Al verse sin medios, ni ocupación para generar ingresos, no le quedó otra opción: regresó a la zona rural de Long Island, con su familia (Moga, en Whitman, 2019). A pesar de haber obtenido una experiencia de cinco años en la industria de la impresión, Walt debió encontrar otra forma de sustento.

De vuelta al lugar de su niñez, sus ocupaciones cambiaron de manera drástica. Walt no deseaba trabajar al lado de su padre en la granja; y ante las nulas opciones periodísticas, consiguió un trabajo de maestro. Esta labor no le resultó nada satisfactoria, pero al menos lo mantuvo ocupado intelectualmente. Aunque su educación formal había sido mínima, su 
aprendizaje autodidacta fue suficiente para instruir a la gente de las áreas rurales neoyorkinas. El joven no disfrutó su periodo de docente, pero la enseñanza le brindó un ingreso para soportar las diversas situaciones de los años 30.

Tiempos difíciles dominaban el panorama económico y político de los Estados Unidos. La inconformidad y la reorganización regían las decisiones nacionales. Andrew Jackson —el personaje admirado por Whitman padre y también por el joven Walt—controlaba las decisiones, de toda índole, en el país. En términos económicos, la actividad industrial ganaba terreno al Norte del territorio, mientras el Sur centraba su interés y sus utilidades en la vida agrícola. La realidad de la tercera década significó un punto de fricción entre los ideales de una nación entera.

Andrew Jackson marcó la vida estadounidense tanto como la del propio Walt. La popularidad del presidente recaía en ser un hombre del Sur, dueño de esclavos, héroe de guerra. Recalcaba su orgullo por haberse hecho a sí mismo y defendía airadamente los derechos estatales por encima del poder federal. Con esos estandartes, su política ensanchó las prerrogativas del poder Ejecutivo "para promover lo que él -y sus numerosos y entusiastas seguidores- consideraban necesario para afianzar su visión política y social.” (Pani, 2016, p. 101). El mandatario tenía injerencia hasta en las mínimas decisión.

Durante su administración, Jackson se dedicó a fortalecer sus alianzas e intereses. Dio prioridad a sus allegados para emplearlos dentro del gobierno federal. Otra decisión determinante para la nación fue desmantelar el sistema bancario. El hecho ocasionó, para 1837, una recesión en las finanzas estadounidenses. La crisis comenzó en primavera y duró hasta mediados de la década de 1840. A lo largo del fenómeno - parecido al de 1819- los bancos colapsaron, la moneda se devaluó. Los precios de los productos se dispararon y los 
agricultores, comerciantes y propietarios de negocios de todo el país sufrieron la ruina o irrecuperables pérdidas financieras (Gibson, 2017).

Las tensiones económicas se sumaron al panorama político. Los acuerdos presidenciales y la fragilidad del sistema bancario, contrastaron las actividades y estilos de vida regionales. Mientras en el Norte sostenía un proyecto industrial y urbanístico, el lado opuesto mantenía una rutina y una base productiva agrícola. El contraste regional estadounidense se pronunciaba cada vez más (Jenkins, 2007). Las decisiones de Jackson no ayudaban a solucionar ningún tipo de diferencias. Al contrario, su ideal de fortalecer la fuerza estatal por encima de la federal, puso en tela de juicio tanto la organización, como la unidad del país.

La manera de oponerse al régimen de Jackson se cimentó en la lucha partidista. Demócratas y Whigs - nombre de tradición inglés y de oposición al absolutismo real del "Rey Andrew"- compitieron para ganar el mandato nacional a través de elecciones. No obstante, el sistema partidista acrecentó las diferencias regionales: "los partidos tenían que responder a exigencias locales, sin que esto resquebrajara unas plataformas nacionales que por definición tenían que ser incluyentes y poco antagónicas.” (Pani, 2016, p. 107). Es decir, los candidatos proponían en beneficio de los gobiernos regionales, siempre y cuando sus propuestas abrazaran al centro o a los ideales de todo el país.

Durante ese periodo caracterizado por las dificultades económicas y el reacomodo política nacional, Walt ejerció la docencia en varias escuelas de Long Island, más de ocho, desde 1836 a 1839. Su gusto por el paisaje rural había quedado atrás: despreciaba la vida del campo tanto como a sus pobladores. Sobre este aspecto escribió una serie de cartas remitidas a un amigo llamado Abraham Leech (en Folsom y Price, 2007): "Nunca antes había tenido una idea tan baja de la belleza y perfección de la naturaleza del hombre, nunca había visto a 
la humanidad en una forma tan degradada como aquí." Sus opiniones las completaba con adjetivos displicentes: ignorancia, vulgaridad, rudeza, presunción y aburrimiento. Esas palabras resaltaban no sólo disgusto, sino desesperación.

A pesar del desagrado, como profesor evidenció un reformismo necesario del sistema educativo estadounidense. Así adquirió su otra voz: ya no la de un observador más que hace reportajes y crónicas, sino la de un escritor comprometido con los problemas nacionales. Esa voz le ayudó a plasmar una postura crítica ante los acontecimientos y conflictos de la sociedad estadounidense. Sus letras definieron su estilo de escritura, además de darle reconocimiento incipiente como articulista. Su vida como docente le permitió interpretar y recrear una perspectiva de la realidad.

Walt se preocupaba por la formación de los jóvenes en un país convulso y necesitado de reformas. Escribió docenas de artículos periodísticos sobre educación, sobre la necesidad de crear nuevos centros de aprendizaje. Las instalaciones debían ser ventiladas y limpias, los castigos no debían ser tan duros, el plan de estudio debía incluir materias como música, arte y educación física. Esos artículos periodísticos, parecían sermones morales y didácticos; expresan un reformismo en las teorías pedagógicas que iba creciendo a la par de un reformismo social (Martín, 2003). Estos primeros escritos cargaban adopción y participación en los hechos y la realidad estadounidense.

Su enfoque estaba en desarrollar el potencial del niño promedio, buscando buenos estándares para promover la enseñanza y el aprendizaje efectivos. Como lo argumentó Hirschhorn (1998), las escuelas rurales no lograban selecciones de maestros adecuadas. Para Whitman, la correcta elección permitiría encontrar maestros capaces de establecer un clima emocional saludable en el aula. De igual manera, el sistema escolar debía enseñar a los niños a confiar y pensar por sí mismos. Esto podía lograrse al cambiar los métodos de enseñanza 
mecánicos y de repetición, por un aprendizaje basado en la motivación. De esto trataba su enfoque y sus aportes a la educación.

Para lograrlo, Walt empleó técnicas poco comunes y progresivas. Alentaba a sus estudiantes a pensar en voz alta en vez de repetir palabras vacías; no castigaba al alumnado con actividades físicas (un correctivo común en la época); involucró a sus pupilos en actividades lúdicas, además jugaba béisbol y cartas con ellos (Folsom y Price, 2007). De cierta manera, trató de ser un profesor ecléctico, nada común, pero interesado en cómo adquirir conocimiento. Walt no tenía la vocación de maestro; sin embargo, quiso transmitir el tipo de educación lograda por él mismo, la que valoraba y la de resultados efectivos.

Aunque la imagen del maestro Whitman suele disolverse en la del bohemio ensoñador y holgazán que recrearon algunos directores, editores y colegas suyos, lo cierto es que su profesión como docente fue algo más que cuestión de estilo o de apariencias (Martín, 2003, p. 20)

Walt interrumpió la enseñanza para probar suerte con su propio periódico, The Long Islander. Su disgusto en las aulas no podía prolongarse más. Con todo lo que había ganado como profesor, compró una imprenta y contrató a su hermano menor George como asistente. Cada semana, Walt subía a su yegua, Nina, para repartir diarios a lo largo de un circuito de 30 millas (Reynolds, 1995). Las entregas llegaban a villas pequeñas de Long Island. A pesar de sus enérgicos esfuerzos por editar, publicar, escribir y entregar, el diario no tuvo ningún éxito. En los años 30, las noticias sensacionalistas dominaban el periodismo estadounidense. Los esfuerzos de Walt no pudieron competir con ese tipo de notas.

El trabajo en su propio periódico duró menos de diez meses. En la primavera de 1839, decidió vender su sueño. La vida editorial le significaba una felicidad infinita. Esa rutina le auguraba mucho más que la docencia. Después de permanecer unos meses bajo el techo familiar - contra su voluntad- y para evitar su continuidad a lo indeseado, decidió 
convertirse en escritor de ficción y restablecerse en el mundo del periodismo. La única condición para nutrir esa carrera era regresar a la vida urbana. Walt no dudó retomar la rutina ofrecida por las grandes urbes de Nueva York: Brooklyn y Manhattan.

En la segunda y tercera década del siglo XIX, Walt Whitman pasó de observar a participar gradualmente en la vida de los Estados Unidos. Su niñez, juventud y los hechos nacionales moldearon su persona, ideas, objetivos, además de su rol como escritor y poeta. En ese trayecto desarrolló su otra voz, no sólo la del aquí y el ahora, sino la del allá, la de las pasiones y las visiones; la de este mundo y la de otros; la del comienzo de la poesía (Paz, 1990). Durante los veinte años posteriores, Walt logró involucrarse aún más con la realidad de su país. Su voz debía ser identificada por toda la nación.

\section{La fuerza de la voz: nombrar la realidad}

Una vez en Manhattan, las labores periodísticas de Walt debían cimentar su futuro como escritor. En 1841, una revolución cultural sucedió gracias a los avances tecnológicos en la impresión. El mundo editorial difería de años anteriores: se había vuelto complejo y de gran escala. Hubo nuevos frentes de lectura, así como cambios en la política editorial: periódicos y pequeñas revistas compartieron una onda expansiva de producción y popularización (Martín, 2003). Walt laboró de cajista en el New World para generar ingresos y así sumergirse a una realidad distinta a la de su niñez.

La revolución editorial de los años 40 se basó en la expansión y la producción de material informativo. Los semanarios alcanzaron circulación y tirajes extraordinarios. Libros y diarios se escribían para el pueblo: de lenguaje sencillo y precio accesible para todos los sectores de la población. El editor del mismo New World, Park Benjamin, pensó que su periódico debía llegar a todos los rincones del país (Martín, 2003). Aquella idea hizo eco en 
el propio Walt: aunque su trabajo como impresor lo hacía sentir cómodo, su meta apuntaba no sólo a plasmar, sino a crear las letras.

Así fue que Walt Whitman cambió su trabajo como cajista para escribir relatos. Muchos de ellos no contaron, según él, con la calidad suficiente para ser recordados. Entre 1841 y 1848, publicó historias en varios periódicos y revistas, como la Democratic Review, una publicación prestigiosa en el país. En sus primeras historias, Walt reflejó sus experiencias como docente. En "Muerte en el aula de la escuela", evidenció los métodos ignorantes y salvajes de castigar a los niños (Folsom y Price, 2007). El cuento trata de un maestro golpeador. Con sus azotes corregía a un alumno, que parecía dormido, aunque el joven había muerto tras haber recibido los correctivos del profesor.

El tono crudo fue una constante en sus historias. En 1842, bajo encargo, en tres días y acompañado de una botella de oporto, Walt escribió su primera y única novela. Franklin Evans, el borracho trataba de un hombre viejo, briago, sumergido en el fondo de las clases sociales. La historia refería tanto los vicios de la población estadounidense, como los de la familia Whitman. El padre de Walt, algunos de sus hermanos y él mismo, durante su etapa de profesor, sucumbieron ante los efectos del alcohol (Moga en Whitman, 2019). El libro vendió más de 20 mil ejemplares por seguir las normas de la revolución editorial: lectura fácil, vocabulario sencillo, un espejo de la vida cotidiana.

Sus ficciones no definieron su estilo, ni mucho menos su carrera de reportero. Walt ganaba reconocimiento al escribir letras en diarios. La rutina citadina le provocó una retórica agresiva y crítica hacia la vida diaria, así como al mundo editorial. Señaló a la policía por hostigar prostitutas. Denunció al obispo John Hughes por utilizar fondos públicos para apoyar escuelas parroquiales. En su estancia en el Aurora, por ejemplo, llenó páginas con literatura, temas locales y culturales, y no sólo de asuntos políticos (Martín, 2003). Creyó en 
la necesidad de hablar de temas distintos, pero siempre bajo un nacionalismo cultural en constante fortalecimiento.

La literatura estadounidense debe ser distinta de todas las demás. -Los escritores deben volverse nacionales, idiomáticos, libres de las leyes gentiles-América debe aparecer (hasta ahora no lo ha hecho) en el espíritu y la forma de sus poemas, y en todas las demás obras literarias-(Whitman, ca. 1845-1855). ${ }^{7}$

El periodismo significó una oportunidad para entonar y comunicar su realidad. Walt trabajó para el Evening Tattler y el Statesman; también para el Log Cabin, el New York Sun y el Mirror. Ese vaivén editorial sirvió para llamar la atención de los lectores hacia sus primeros trabajos - ficciones, poemas y piezas periodísticas-. Poco a poco su escritura y estilo se transformarían: de trabajos pedestres a una poesía mayor. Sus ficciones se vendieron con éxito y sus primeros poemas se reeditaron. Si bien su magna obra, Hojas de Hierba, vería la luz hasta 1855, en la cuarta década sus creaciones se posicionaron de manera crítica hacia los hechos de su alrededor.

Tras la estadía en Manhattan, Walt regresó a Brooklyn en 1845. En ese lugar tan conocido por él desde su infancia, continuó sus labores en los diarios; además adquirió una afinidad con los eventos culturales citadinos. De las funciones de ópera, por ejemplo, admiró la perfecta coordinación entre los movimientos del cuerpo y la voz. Whitman dijo una vez (en Folsom y Price, 2007), después de asistir a una función, “que ese tipo de experiencias podían renovar el alma de cualquier persona afín a la ópera.” Al regresar a la ciudad de su infancia, su voz se involucró con el panorama social, cultural, político y urbano.

Desde marzo de 1846 a enero de 1848, Walt se desempeñó como editor del Daily Eagle. Su trayectoria creativa tomó una curva ascendente, pues recorrió el panorama cultural

\footnotetext{
${ }^{7}$ Véase "American literature must become distinct".
} 
y político estadounidense. Sus palabras se tornaron inquisidoras. Su permanencia en el Eagle significó un lugar para combatir, argumentar y cuestionar sobre los sucesos locales y nacionales. Como editor, comentó sobre varios temas: el alumbrado público, la política, la banca y la poesía. Valoraba la capacidad de promover sus opiniones, pero en especial, la intimidad o simpatía generada en los lectores de los diarios. Sus letras buscaron ligar a cada lector con su estilo cultural periodístico.

Porque recuerden que detrás de toda esta demostración de vida aparente, todo hombre y mujer, - de las que escuchan ahora [ien?]-. Estas charlas, diversiones, vestimenta, dinero, política, etc., destaca la vida real de cada hombre y mujer que me escucha ahora (Whitman, ca. 1845-1860). ${ }^{8}$

Walt buscó crear una empatía entre el periódico y el público. Acercó a la población a los temas en boga dentro de la política nacional: la guerra con México, la esclavitud, la tensa relación entre los estados. Junto al panorama político, estimuló el conocimiento literario al publicar obras clásicas. Editó reportajes sobre ópera museos y salones de actividades culturales. Desde su oficina en la calle Fulton, observaba para informar de los asuntos en Brooklyn y en el país.

Uno de los temas abordados durante su gestión en el Eagle fue la esclavitud. Walt defendía los intereses de la clase trabajadora blanca. Su postura reflejaba temor e incertidumbre: una "marea negra" podía acabar con las oportunidades laborales de los hombres blancos en los recién adquiridos territorios del Oeste. Permitir la esclavitud ahí, lo consideró un error de grandes magnitudes (Martín, 2003). Walt se opuso a la esclavitud no por el debate entre libertad o sumisión, sino por un tema de beneficio o afectación hacia la raza blanca. Poco a poco, esa opinión cambió debido al cúmulo de hechos nacionales y su viaje a Nueva Orleans.

\footnotetext{
${ }^{8}$ Véase "For remember that behind all".
} 
En los Estados Unidos, la consolidación del sistema esclavista se había llevado a cabo bajo un largo proceso de legislación. A finales del siglo XVIII, los padres de la patria -muchos de ellos dueños de esclavos- vieron a la esclavitud como un fenómeno incómodo, inmoral y arcaico. Consideraban que, aunque no podían escapar de ella de forma inmediata, esa institución estaba en vías de extinción. Acto seguido, y en contraste a los argumentos, se implementaron constitucionalmente mecanismos, matizados, para proteger esta institución. Una de las medidas más importantes fue evitar la palabra "esclavo" en el texto de la Ley fundamental (Pani, 2016).

Las posturas y diferencias regionales a partir de la esclavitud se acrecentaron en la vida nacional. En 1815, se cifró en 8.5 millones los habitantes en todo Estados Unidos. De ese número, 1.5 millones eran afroamericanos, y de ellos, 1.3 millones eran esclavos. En el Sur habitaba, en su mayoría, una sociedad de blancos libres acompañada de una minoría sometida a la esclavitud (Adams, 1979). La parte Sur de los Estados Unidos defendía y excusaba su postura con argumentos positivos e incluso modernos: era benigna, provechosa, así como la más antigua y la mejor forma del socialismo (Pani, 2016). El país obtuvo dos perspectivas de un sólo tema.

Para 1820 y 1830, la esclavitud se había consolidado como una institución. En 1820 fue aprobada la ley del paralelo 36 $30^{\prime}$ (Ver Mapa 1). Al Norte de esa línea imaginaria, la libertad predominaría. Por debajo de la misma, la esclavitud sería permitida para manipular la tierra y los productos de ella. Dos sociedades, norteños y sureños, se establecieron y diferenciaron una de la otra. En la parte Sur, existía una poderosa élite de plantadores esclavistas dominantes de la vida política. Con esa fuerza, recurrieron a utilizar los instrumentos del gobierno para reforzar sus posturas. La situación comenzó a afectar el contexto de la política federal estadounidense. 


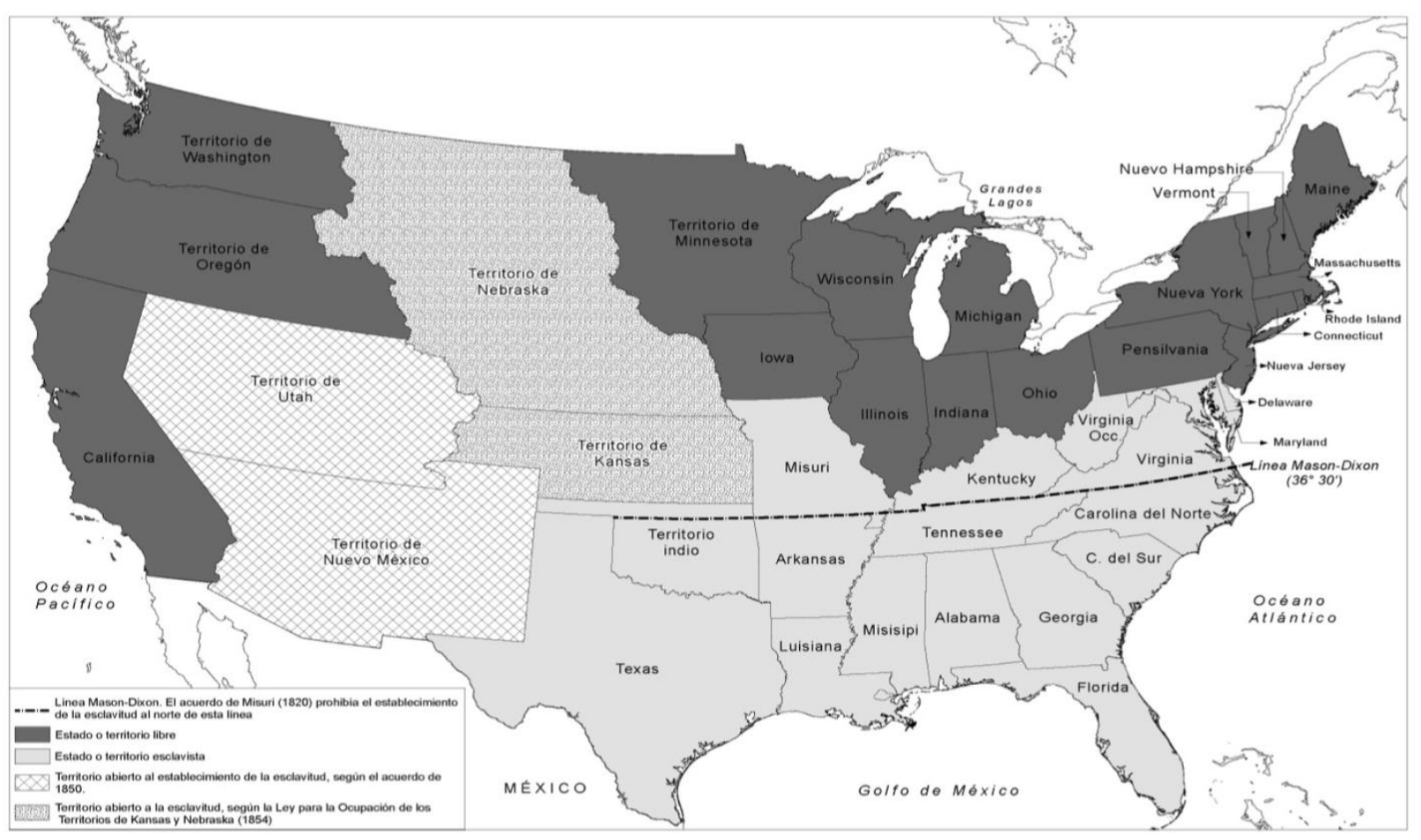

Mapa 1: La esclavitud y sus consecuencias políticas (Pani, 2016).

Los sureños tenían una actitud combatiente y defensora de sus ideales. Para imponerse en el contexto de la política federal, acudieron a la sobrerrepresentación en el Congreso. Adaptaron las clausulas constitucionales para ganar las elecciones presidenciales con un amplio margen de votos a favor. Con esa ventaja, entre 1836 y 1844, consiguieron prohibir discusiones abolicionistas. También acallaron los escritos incendiarios que difundían las críticas a la esclavitud (Pani, 2016). Encubrir el tema bajo el dominio de las políticas volvió frágil y acrecentó un aire divisorio en la federación.

La esclavitud llegó a otras latitudes y basada en otros hechos. Para la década de los 40, era una institución consolidada regionalmente, aunque presente en todo el territorio nacional. En 1848, Estados Unidos declaró la guerra México. Ante una posible anexión del terreno mexicano, los intereses sureños veían con buenos ojos la suma territorial. El lado 
Norte contraatacó esa idea con la controversia siguiente: de haber anexión, los terrenos admitidos entre 1846 y 1849 serían libres (Martín, 2003). Los hechos se desarrollaron de manera distinta. No obstante, aquella beligerancia tensionó, aún más el polémico tema.

A la pugna se sumó la decisión de California como parte del llamado Compromiso de 1850. Ese lugar se decantó por ser territorio abolicionista, aunque la mayoría del mismo yacía más allá de paralelo $36^{\circ} 30^{\prime}$. El lado Sur no sólo vio mermadas sus posibilidades de establecer sus ideales, también debía alinearse a la política del Norte. A pesar de las limitaciones territoriales, un logro sureño fue la "Ley del Esclavo Fugitivo". ${ }^{9}$ Aunque el estatuto no aliviaba las tensiones territoriales, sí definía los ideales esclavistas del Sur.

Walt Whitman adaptó su postura en contra de la esclavitud. Seguía temeroso de la "marea negra" arrebatadora de empleos, pero las prácticas esclavistas per se le provocaron indignación. Se escandalizó por las leyes de importación de esclavos a través de Brasil. Al igual que Abraham Lincoln, se opuso sistemáticamente a la esclavitud y su posterior extensión. En un incidente famoso, Walt perdió su puesto como editor del Eagle, pues el fundador del diario, Isaac Van Anden, apoyó a los demócratas conservadores, así como a las prácticas esclavistas (Folsom y Price, 2007). Las diferencias e ideas afectaban tanto a la nación como al propio periodista.

Pocos días después del incidente con el dueño del Eagle, Walt se embarcó en una nueva aventura definitoria para su rol como poeta. El 9 de febrero de 1848, recibió una oferta de ser el editor de un periódico en Nueva Orleans, el Crescent. Le bastaron 15 minutos para aceptar la oferta. Quien le propuso el trabajo le proporcionó un anticipo para cubrir sus gastos

\footnotetext{
${ }^{9} \mathrm{Si}$ el esclavo era juzgado y dictado por un comisionado federal, ninguno de los derechos de individuo libre podía ser aplicados al esclavo. La raza era predeterminante de culpa. Además, todos los individuos del territorio tenían prohibido ayudar a escapar o rescatar a un esclavo fugitivo. Véase esa ley en, "Fugitive Slave Act", retomado de [https://avalon.law.yale.edu/19th_century/fugitive.asp]. Consultado en abril 2020.
} 
de viaje. A esa oferta se sumó Jeff, un hermano menor de Walt, para trabajar como empleado de oficina (Folsom y Price, 2007). Ese fue el primer viaje de Walt fuera del campo o las ciudades de Nueva York. El hecho le ayudó a ampliar la compresión y la diversidad existente en la parte Sur del país.

En Nueva Orleans permaneció por tres meses. Allí se encontró con una gama de colores y emociones. Deambuló por el barrio francés y sus mercados. Admiró la capacidad de los comerciantes indios y negros para convencer a los clientes. La "gran mulata criolla" le vendió el mejor café que jamás probó. Disfrutó de los bares llenos de vinos exquisitos y conoció a los soldados que regresaron de la guerra con México. Esos fueron sus primeros encuentros con jóvenes combatientes. Esta ciudad le mostró rostros distintos a los de su cotidianeidad neoyorkina.

Nueva Orleans también le mostró la realidad, no sólo debates, de la esclavitud. Además del folclor, de la mezcla de idiomas (francés, español e inglés), base de la fusión de razas y orígenes, el exotismo de la ciudad también poseía horrores: muchos esclavos eran subastados a la vuelta de la esquina de Lafayette Square. El ser humano también podía tratarse como una mercancía. "La venta de esclavos debía resultar chocante para una sensibilidad como la suya.” (Martín, 2003, p. 30). Walt desarrolló una voz poética distinta tras esa experiencia. En el poema "Canto el cuerpo eléctrico", pudo congelar un momento tan común de aquella ciudad sureña.

$[\ldots]$

Se subasta un cuerpo de hombre

(Porque, antes de la guerra, yo iba mucho al mercado de esclavos, y presenciaba las ventas).

Ayudo al subastador porque el muy inepto no sabe nada del negocio. $[\ldots]$

No es sólo un hombre: es el padre de los que serán, a su vez, padres;

En él, el origen de estados populosos y prósperas repúblicas;

De él, innúmeras vidas inmortales, con innúmeras encarnaciones y 
$[\ldots]$

alegrías.

El cuerpo de una mujer en subasta

Ella también no sólo es ella misma, es la madre de madres,

Ella es la portadora de quienes crecerán y serán compañeros de las madres.

¿Has amado alguna vez el cuerpo de una mujer?

¿Has amado alguna vez el cuerpo de un hombre?

¿no ves que son exactamente los mismos para todos en todas las

naciones y en todas las épocas de la tierra? [...]

(Whitman, 1855, versos 95-97 [...] 113-115 [...] 118-120)

Ese lugar exótico y plural era distinto a Brooklyn o Manhattan. Además de la esclavitud, otros ecos políticos retumbaron en sus oídos. La guerra con México había generado un ambiente patriótico y de fervor popular por anexionar el terreno mexicano. Esta idea elevaba a los Estados Unidos como una fuerza militar y política capaz de dominar otras naciones y moldearlas a su manera. A pesar de ese entusiasmo expansionista, Walt no estaba de acuerdo con establecer la esclavitud en esos territorios.

Como persona del Norte, no le fue fácil tener una postura neutral. Walt estaba de acuerdo con la inclusión del territorio mexicano, pero la esclavitud no podía ser permitida. Su rechazo a todas las posturas a favor de las causas sureñas provocó la ruptura laboral con el Crescent. No pudo permanecer neutro ante los debates políticos. Después de tres meses de estadía, dejó ese trabajo y la ciudad de Nueva Orleans (Martín, 2003). Aun así, el lapso fuera de Nueva York le enseñó las decisiones compartidas entre él y su país; así como otras difíciles de aceptar.

De vuelta a su zona de confort, Walt analizó las circunstancias divisorias de los Estados Unidos. Desde las trincheras periodísticas norteñas comenzó a idear una solución nacional. El riesgo de no conjugar posturas distintas podría herir de manera profunda la vida nacional, así como a la de sus habitantes. Un pilar debía existir para conjugar ideales: “[...] desde el momento en que un hombre toma la página más pequeña exclusivamente para sí 
mismo, y trata de mantenerla alejada del resto, a partir de ese momento, comienza a marchitarse bajo su mano."10 (Whitman, ca. 1850-1860). La democracia debía ser el punto de convergencia entre las posturas abolicionistas del Norte y esclavistas del Sur.

Su trabajo como poeta comenzó a rendirle versos de elegía:

$[\ldots]$

(Democracia, mientras que las armas estaban en todas partes apuntando a tu pecho,

Te vi serenamente dar a la luz a niños inmortales, vi en sueños tu forma de dilatación,

Te vi con un manto que se extendía cubriendo el mundo).

(Whitman, 1855, versos 297-299) ${ }^{11}$

Pero este sueño y solución democrática se estrellaba constantemente ante un proceso de desunión incontrolable. En 1850, norteños y sureños despojaron de racionalidad a sus argumentos y acciones. Para los del Sur, sus oponentes habían acosado sus privilegios territoriales hasta el límite; debían defenderlos a toda costa. Los del Norte no veían a sus contrarios como una cultura preindustrial, sino como una zona obsesionada de basar su poder político, económico y cultural en la esclavitud (Adams, 1979). La quinta década cimentó un camino hacia la disgregación. La esclavitud no podía confinarse a una sola área, ni cubrir el interés de todo el territorio estadounidense.

Los años 50 relataron un separatismo anunciado y formado décadas atrás en los Estados Unidos. "Los consensos - nunca automáticos ni permanentes- en torno al gobierno descentralizado, a la democracia de los hombres blancos y a la expansión territorial coincidieron con el dinámico desarrollo de una economía comercial vigorosa pero inestable.” (Pani, 2016, p. 121). Aunque el país había logrado grandes transformaciones políticas, financieras, culturales y sociales, también desarrolló desacuerdos gigantes. Las decisiones

\footnotetext{
${ }^{10}$ Véase "The idea of reconciliation".

${ }^{11}$ Este poema se intitula "By Blue Ontario Shore".
} 
políticas sobre la esclavitud mostraron a una política federal vulnerable. El orden nacional sólido parecía sólo un anhelo.

A la par de la nación, Walt sufrió un periodo de inestabilidad, pero de antesala de su poesía. De 1849 a 1855, su situación económica no fue la mejor. Abrió una pequeña tienda donde vendió diversos productos. Después decidió transformarla en una librería-imprenta, para perseguir su sueño de ser escritor. A pesar de sus esfuerzos, tal y como su padre, los negocios no fueron su fuerte. Cerró su pequeño local y se dedicó a la construcción. Todas esas actividades las complementó mientras colaboraba como reportero para el Evening Post (Moga, en Whitman, 2019). Lo anterior significó un proceso de sustento y preparación para saltar a la escena como poeta.

En medio de la disparidad nacional, Walt Whitman publicó la primera edición de su obra Hojas de hierba, en 1855. Supervisó todos los detalles de su composición e impresión, así como su distribución y recepción. Diseñó el libro y compuso los tipos - debido a su experiencia como cajista durante su juventud-. El volumen contó con doce poemas sin título y un prefacio, no incluido en ediciones posteriores. Además, esa primera edición tampoco indicaba el nombre del autor en la cubierta. A finales de junio de 1855, el poemario intentó unir e identificar una solución para las disputas de la realidad.

Whitman intentó conjuntar en su obra el periodismo, la ficción y los problemas sociales desafiantes de la nación. Sus Hojas buscaron contener la solución de esas diferencias: un verso experimental emitido en largas líneas sin rima sin métrica identificable, la voz una extraña combinación de oratoria, periodismo y profecías, así como un espíritu democrático sin precedente. (Folsom y Price, 2007). Ese libro amalgamó imágenes y sonidos al servicio de la nación. 
Mientras la mayoría de la gente se alineaba de un lado o del otro, el poeta se colocó en ese espacio, conciliador, democrático. Sus versos respondían a la situación política estadounidense. Con su voz afirmó con seguridad su postura en defensa de la unión en un momento de increíble división y tensión. Habló también de la idea del "yo", un curandero de la cultura, de la conjunción del todo (Folsom y Price, 2007). Su postura era apasionada ante las posibilidades democráticas y de renacimiento nacional.

La voz del poeta presentó en la primera edición de su obra las causas de muerte de su propia nación: norteños y sureños estaban prácticamente sobre el cuello uno del otro. El esfuerzo de Whitman apuntó constante a vincular y a aliviar las disputas de estos grupos. “Cuando abordó directamente los problemas de cada sección, así como de la esclavitud, su poesía alcanzaba también un término medio.” (Martín, 2003, p. 38). No le tembló la voz, ni la pluma, para reclamar las turbulencias y pestilencias nacionales.

A pesar del ímpetu y la intención por promover una solución, Hojas de hierba, no tuvo ningún éxito. Las ventas fueron pocas y su impacto nulo. Whitman reeditó su poemario en 1856, mientras llevó un estilo de vida bohemio. Se hizo un habitual asistente del restaurante Pfaff, donde se reunían intelectuales y artistas neoyorkinos: Emerson, Thoreau, Alcott. Al mismo tiempo, tuvo contacto con feministas de esa época como Sara Willis, Paulina Wright Davis y Sarah Tyndale (Moga en Whitman, 2019). Whitman fracasó dos veces en dos años, sin embargo, eso le ayudó a forjar conexiones literarias. Comenzó a socializar y a cultivar su imagen como artista.

Después de la derrota de la segunda edición de sus Hojas, el poeta sostuvo un ritmo constante de escritura. Escribió casi setenta nuevos poemas, las cuales imprimía y costeaba para corregirlos. Después de cuatro años, en 1860, mientras la nación avanzaba hacia una gran crisis política, la suerte de Whitman dio un giro positivo. En febrero, recibió una carta 
de un par de editores en Boston: William Thayer y Charles Eldridge. Aunque ellos publicaban trabajos enfocados en promover la literatura abolicionista, también quisieron convertirse en los editores de una nueva edición de Hojas de Hierba.

El tercer intento corrió con mucha más suerte que los anteriores. Whitman accedió fácilmente a la oferta de Thayer y Eldridge. La edición tuvo más de 450 páginas. Whitman viajó a Boston para supervisar la impresión. Los periódicos locales publicaron artículos sobre su visita. Durante todo el verano leyó reseñas de su trabajo en periódicos y revistas importantes (Folsom y Price, 2007). Aunque no fue inmediata, la relevancia de Whitman resultó de un proceso largo y de trabajo constante.

A pesar de haber ganado fuerza en su voz y letras, el canto de Whitman se deshizo ante la realidad. La división de posturas políticas significó un punto de quiebre para la vida estadounidense. Esta división tuvo su cúspide en 1860 con la elección de Abraham Lincoln como presidente de los Estados Unidos. Su elección fue la chispa detonadora de las diferencias y de un proceso de secesión. Lincoln recibió menos del 40 por ciento en la votación popular. Sin embargo, los votos electorales significaron el 59 por ciento de aprobación (Jenkins, 2007). Esto fue suficiente para sentar a Lincoln en la Casa Blanca.

El radicalismo no desapareció de los argumentos de cada bando. Para los del Norte, la elección presidencial demostraba la pertenencia de una sola nación indivisible. Para la parte Sur, tal elección concibió un pacto voluntario hecho por unos cuántos. "Durante su toma de posesión, el presidente Lincoln acertó un golpe a los sureños al asegurar que los intereses esclavistas no debían inmiscuirse en zonas donde ésta no existe.” (Adams, 1979, p. 93). Las palabras se volvieron insuficientes para concordar.

La idea de la cordialidad comenzó a borrarse en ambas posturas. En diciembre de 1860, Carolina del Sur comenzó la separación. Le siguieron, para 1861, Florida, Georgia, 
Alabama, Mississippi, Louisiana y Texas. Esos territorios formaron la Confederación de Estados de América y eligieron a su presidente Jefferson Davies. En marzo, la Confederación envió representantes a Washington para negociar la evacuación de fuertes e instalaciones federales. Ellos no formarían parte de los Estados Unidos. Tales pretensiones fueron rechazadas por la Federación. El hecho motivó lo inevitable: tropas confederadas del Sur atacaron el Fuerte Sumter, en Charleston, el 13 de abril a las 4:30 de la madrugada.

Whitman se volvió parte de cada momento, cada tensión política, social y económica de su país. "Cada nación tiene un poeta o un escritor en el que resume la gloria intelectual de la nación o de la raza." (Gramsci, 1972, p. 338). Su voz provenía de un país en conflicto, pero en búsqueda de soluciones. No debía tomarse partido por los estados del Este o por los del Oeste; o tomar partido por la parte Norte o por los estados del Sur del país. La unidad debía prevalecer ante cualquier adversidad. Sin embargo, su voz también se quebraría debido a las cruentas experiencias vividas durante la Guerra de Secesión.

\section{Un mismo ente: el poeta, la guerra y su obra}

La Guerra Civil comenzó tras haber acumulado palabras y hechos en décadas anteriores. Las tensiones políticas, regionales, económicas, y sociales - surgidas desde los años 20 y complicadas durante 40 años- no pudieron mantenerse en un plano ideológico o en debates. El país estaba dividido y con diferencias arraigadas en el corazón del Norte y el Sur. Enfrentarse para decidir entre las fuerzas abolicionistas o los ideales esclavistas. La confrontación resultó inminente y sus escalas no tenían precedentes: participaron casi tres millones de hombres, de los cuales murieron un poco más de 600 mil.

La Guerra Civil [...] amenazó con destruir el que había sido el experimento republicano más exitoso de América. [...] La guerra clausuró el proyecto de república confederada fincado en la perpetuación 
de la esclavitud, y liberó a cuatro millones de esclavos (casi 13\% de la población). Costó más de 6,000 millones de dólares, más del doble de lo que se hubiera requerido para indemnizar a los amos y liberar a los esclavos en 1860 (Pani, 2016, pp. 123-124).

La historiografía norteamericana ha mostrado divisiones y discrepancias. Muchos historiadores, depende de la región donde han escrito, llaman a las batallas de una manera. Para otros, el simple nombre crea polémica: llamarla Guerra de Secesión significa adoptar una postura unionista y en contra de los confederados. De igual manera, los orígenes del conflicto han sido tema de polémica: incompetencia política, patriotismo, defensa de la esclavitud, autonomía estatal, superioridad moral e industrial norteña, o la capacidad de movilización militar, son temas que salen a la luz. Lo cierto es que ese suceso afectó de manera radical la vida de la población estadounidense.

Una de esas vidas fue la de Walt Whitman. La beligerancia lo impactó ya con cuatro décadas cumplidas. En 1861, seis años después de escrito Hojas de hierba y exponer una solución democrática para las diferencias nacionales, se supo demasiado viejo y sin espíritu para pelear: "La idea de reconciliación, sobre lo sucedido, se consume. Siempre, fuera de cenizas, que maduren frutos nuevos, más dulces y amigables.” (Whitman, ca. 1854-1860). Whitman analizó y asimiló la situación. Observó la inminente ruptura, pero también guardó silencio en espera de los hechos.

El estallido de la guerra había sorprendido a propios y extraños. En febrero de ese año, Whitman había visto a Abraham Lincoln, en Nueva York, camino a su investidura. Dos meses después, en abril, el poeta volvía a casa después de una función de ópera cuando compró un periódico y leyó los titulares: las fuerzas del Sur habían disparado contra el Fuerte Sumter. Reuniones grupales sucedieron en las calles de Nueva York: quienes tenían los 
periódicos en mano leían la historia en voz alta a las multitudes (Folsom y Price, 2007). La nación haría frente a los desafíos de la unión y a los sacrificios de la guerra.

Año armado-de lucha,

No rimas delicadas o versos de amor sentimental para ti, año terrible

$[\ldots]$

Escuché tu voz determinada y lanzada una y otra vez,

De repente, cantaste por las bocas redondas del cañón

Te repito, apresurándote, estrellándome, triste y distraído año.

(Whitman, 1865, versos 1-2 [...] 14-16) ${ }^{12}$

Al principio, el panorama ilustraba un enfrentamiento desigual y con un pronto desenlace. La parte Norte del territorio contaba con superioridad de habitantes, 19 millones, así como de recursos materiales. Por el contrario, en el lado Sur vivían 9. 5 millones, de las cuales la tercera parte eran esclavos. La desigualdad numérica, además de las actividades económicas, representaron una diferencia mayor (Reynolds, 1995). Los nordistas -la Unión- poseía autosuficiencia en recursos; los sureños - los confederados- dependían de su actividad agrícola. Ambos factores cimentaron el siguiente pensamiento: la ofensiva sería rápida y favorecería a la facción nordista.

Los jóvenes respondieron de manera pronta al llamado de las armas. Su entusiasmo se fundó en una creencia: "La guerra sería una especie de día de campo, en el que se divertirían vistiendo uniforme, disparando a un enemigo desconocido y distante y durmiendo en casas de campaña." (Pani, 2016, p. 133). Las fuerzas armadas se integraron por voluntarios, más que por militares formados. Incluso, el Ejército confederado rechazó a 200 mil entusiastas reclutas en pro de la causa sureña. Nadie se atrevía a alentar el conflicto por más de dos meses. No obstante, el enfrentamiento resultó uno de los más largos de la historia estadounidense.

${ }^{12}$ Véase el poema "Eighteen Sixty-One". 
La Guerra Civil se ha considerado una de los primeros enfrentamientos modernos. Como pensó Daniel Sutherland: "los temas de la guerra total siempre se han dado con la interrupción de la base logística del enemigo y de la destrucción moral civil.” (en Wayne, 2011, p. 398). ${ }^{13}$ La conflagración resonó en grupos civiles excluidos en enfrentamientos anteriores: la armada y la marina enlistaron afroamericanos en sus filas; las mujeres se encargaron de empleos ajenos al hogar —en escuelas, hospitales, oficinas, fábricas-; las libertades individuales fueron suprimidas por el gobierno del presidente Lincoln, si éstas se consideraban subversivas y atentaban contra de los ideales de la Unión. Una guerra total.

Las estrategias y la tecnología militar sustentaron la longitud y el alcance del conflicto. Los militares involucrados compartían los mismos planes de batalla, pues tanto unionistas como confederados habían asistido a West Point: dominar el territorio y tomar objetivos específicos eran la constante de los bandos. Aunado a esto, las armas de repetición, como rifles, cañones y balas aumentó la capacidad de daño y efectividad. Los tiros eran exactos hasta con 800 metros de distancia (Pani, 2016). Estas características dieron pie a batallas sangrientas, inmensas en pérdidas, pero sin un pronto desenlace.

La beligerancia tomó parte del imaginario del poeta. Los ideales de conciliación y unidad estaban amenazados. La voz de reconciliación de Whitman lucía mediadora entre los adversarios. La guerra no debía verse como una cruzada para combatir la esclavitud, sino como un enfrentamiento dañino para los involucrados. El camino y la resolución podían dirigirse hacia la obtención de la libertad democrática. El pensamiento del poeta buscaba

\footnotetext{
${ }^{13}$ Para cumplir esta característica, el conflicto debe adentrarse en la rutina y hasta en la moral de la vida civil. "[...] principal themes have always been the disruption of the enemy's logistical base and the destruction of civilian moral."
} 
otorgar un sentido distinto al conflicto: uno no tan radical, pero afianzado en la victoria de la democracia. Ella traería la mejor solución para ambos lados.

Desde Paumanok comienzo mi vuelo como un ave Doy vueltas de aquí allá, canto la idea de todo, Al Norte entono canciones árticas, En Canadá canto hasta que absorba a Canadá en mí mismo, después vuelo a Michigan,

A Wisconsin, Iowa, Minnesota, para cantar sus propias canciones (son inimitables)

Luego, en Ohio e Indiana canto las suyas, en Missouri, Kansas y Arkansas hago lo mismo,

A Tennessee y Kentucky, a las Carolinas y Georgia vuelo para tararear sus canciones, Sigo a Texas y voy hasta California, vago por todas partes; Para cantar primero, (con el redoble de tambor si es necesario) La idea de todos, del mundo occidental único e inseparable, Y luego la canción de cada miembro de esos Estados. (Whitman, 1865). ${ }^{14}$

La voz de Whitman, a pesar de lo radical del enfrentamiento, siempre se dirigió al anhelo de unión y de victoria rápida. El tono de comunión lo había construido desde sus poesías anteriores, aunque miraba al conflicto como una forma inevitable de conseguir la tan buscada reconciliación. Como hombre crecido y formado en el Norte, su postura apostaba a esa idea. El conflicto había estallado y al sólo quedaba esperar una victoria rápida y a favor de la Unión. Tal vez por esa razón durante los primeros dos años de guerra, de 1861 a 1862 , la producción literaria y poética de Whitman fue casi nula. Su reacción no fue poetizar la guerra sino captarla, observarla y tratar de entenderla.

Durante los dos primeros años del conflicto, Whitman no creó ningún verso. Su vida la gastó en medio de editoriales y periódicos. Su trabajo como editor y reportero se enfocó en poner en el panorama de sus lectores los riesgos de la división. Así también advirtió sobre la necesidad de la unidad nacional para resolver los problemas a través de la vía político. Su

\footnotetext{
${ }^{14}$ Véase el poema "From Paumanok Starting I Fly like a Bird".
} 
postura se mostró crítica, pero alejada del conflicto. Su producción y escritura se dedicó a resaltar la historia de la ciudad que lo había acogido durante sus años de formación, Brooklyn.

Los dos primeros años de la guerra lucieron nebulosos en la vida de Whitman. Sus artículos sobre la vida citadina se publicaron en el Brooklyn Daily Standard. Esas piezas, "Brooklyniana", constan de veinticinco entregas. Juntas forman un libro de historia anecdótica de la ciudad tan conocida por el poeta. En contraste, Folsom y Price (2007) señalan a ese período de pausa poética, donde Whitman se encontró de frente con víctimas de la guerra. Allí comenzó a visitar a soldados heridos que fueron trasladados a hospitales de Nueva York. Escribió sobre ellos en una serie llamada "Fotografías de la ciudad", publicada en el New York Leader, en 1862. Su trinchera era el periodismo.

Mientras la creación poética permanecía en silencio, un evento marcó un cambio en la vida de Whitman. George Washington Whitman, uno de sus hermanos menores, se había enlistado en el $13^{\circ}$ Regimiento de Brooklyn. Si el poeta no podía participar, su hermano lo representaría en el campo de batalla. Para el escritor, así como para toda la nación estadounidense, en especial para la parte del Norte, la guerra sería fugaz: "Todos los que estamos aquí pensamos que la rebelión se ha roto, no importa si la guerra continúa durante unos meses más."15 (Whitman, 1861). Los hombres enlistados regresarían rápidos y triunfantes. Su hermano no sería la excepción.

Los hechos se mostraron distintos. La Unión llevó la voz cantante y agresiva durante la beligerancia. En 1862, cerca del riachuelo de Bull Run, los ejércitos involucrados intercambiaron fuerzas. El enfrentamiento parecía un avance tranquilo para el Norte. En contraste, las fuerzas confederadas resistieron el embate y obligaron la retirada de sus

15 "Walt Whitman to George Washington Whitman, 12 July 1861". 
oponentes. Después de perder esa batalla, la Unión se empecinó en tomar Richmond, un punto clave del bando Sur. "En el otoño y el invierno de 1862, y la primavera de 1863, se hicieron tres nuevos ensayos con el resultado parecido.” (Adams, 1979, p. 97). Tanto la batalla cerca del río, como los ensayos por tomar Richmond, aletargaron el conflicto.

Si bien los escritos anteriores de Whitman muestran una suerte de mediación entre ambos bandos, los debates, la violencia creciente y el estallido de la guerra lo llevaron a creer ciegamente en las intenciones del bando nordista: representaba su visión patriótica. $\mathrm{Su}$ hermano, como se ha señalado, luchaba por defender los ideales nordistas. El poeta estaba consciente y era conocedor del precio de la guerra. Las vidas humanas eran sólo un pequeño costo por pagar si éstas aseguraban la continuación de la unidad nacional. Las pérdidas estaban implícitas para lograr la victoria. Su pluma poética despertó, tal y como lo muestra el primer poema de Redoble de tambor, "Primera canción para un preludio".

Los regimientos armados llegan todos los días, pasan por la ciudad y se embarcan desde los muelles.

(¡Qué bien se ven cuando recorren los ríos, sudorosos, con sus armas en los hombros!

¡Cómo los amo! ¡Cómo podría abrazarlos, con sus caras marrones y sus ropas y mochilas cubiertas de polvo!)

$[\ldots]$

¡Guerra! ¡Una armada avanza! La bienvenida para la batalla, sin echar marcha atrás;

¡Guerra! Ya sean semanas, meses o años, una armada avanza para darle la bienvenida.

(Whitman, 1865, versos 31-33[...] 46-47).

La lucha se prolongaba y en el frente había un familiar. Whitman fue afectado de manera directa: en el invierno de 1862, el batallón donde estaba enlistado su hermano George sufrió un ataque en Fredericksburg, Virginia. Si algo debe quebrarse en mil pedazos, es necesario haber impacto en el mero centro del objeto. Walt tomó cincuenta dólares, una muda de ropa, varios cuadernos para anotar durante el trayecto y las ganas de encontrar a su hermano con vida. Le tomó tres días llegar a la Mansión Chatham, un hospital para las fuerzas 
unionistas (Reynolds, 1995). Había una razón suficiente para enfocar de forma distinta la contienda.

En diciembre de ese mismo año, el poeta escribió a su madre con la misión completada. Él había encontrado a su hermano. Tanto la vida de los Whitman como la guerra habían abordado una montaña rusa de emociones. "Fuera de la política, los triunfos, las batallas, la vida, ¿qué queda al fin de las cosas?” (Whitman, 1865, versos 5-6). ${ }^{16}$

Viernes 19. Logré llegar al campamento de la 51 en Nueva York y encontré a George vivo y bien [...] Él está saludable, tiene buen apetito; creo que a veces está más cansado y nostálgico de lo que se muestra, pero lo soporta de la mejor manera. Cada uno de los soldados quiere llegar a casa (Whitman, 1862). ${ }^{17}$

Después de este episodio de búsqueda e incertidumbre, Whitman retomó su actividad poética. Su cambio de perspectiva, observación y escritura no sólo ocurrió durante la búsqueda de George. Ésta se complementó al atestiguar las experiencias de los involucrados en el conflicto. La guerra entraba en una etapa madura, donde los años pasaban y la solución no se alcanzaba. Para 1863, 1864 y 1865, Whitman tuvo la convicción de volverse enfermero voluntario en varios hospitales de Washington D.C., Nueva York y Brooklyn. Su participación no sucedería en el campo de batalla, sino desde el lugar donde el conflicto podía tomar pausas.

Larga, muy larga América,

Viajo por tus caminos tranquilos, ahí se aprende de las alegrías y de la prosperidad,

Pero ahora, ah ahora, se aprende de las crisis, de la angustia, se avanza, y se lidia con el destino más terrible y es imposible retroceder,

Ahora es necesario concebir y mostrar al mundo lo que realmente son tus hijos,

(¿Porque quién, excepto yo mismo, ha concebido lo que realmente son sus hijos? (Whitman, 1865) ${ }^{18}$

\footnotetext{
16 Véase el poema “Quicksand Years".

17 "Walt Whitman to Louisa Van Velsor Whitman, 29 December 1862".

18 "Long, too long America".
} 
Durante tres años, la labor de cuidar amputados, enfermos, heridos, así como despedir a los soldados muertos, le mostró una nación desgarrada por el dolor. Whitman trabajó también como oficinista de medio tiempo y como colaborador ocasional en algunos periódicos. Así ganó lo suficiente para mantenerse y ayudar a las huestes enfermas. Dentro de galeras improvisadas, prestó voz a los combatientes, plasmó en letras la esperanza de otros por volver a casa. Sus dificultades personales parecían mínimas en comparación a su alrededor. El mejor testimonio para ilustrar estas situaciones es "El curador de heridas". Tal poema demerita las causas del conflicto. Los estragos no sustentaban motivos, ni ideales:

Adelante, voy, ( $¡$ abran las puertas del tiempo, abran las puertas del hospital!)

Aplico un vendaje a una cabeza aplastada (la mano enloquecida no arranca la venda,)

Una bala atravesó el cuello del hombre de la caballería, yo lo examino,

Mi respiración vibra, mis ojos se llenan de lágrimas, pero su vida se aferra

(¡Dulce muerte! ¡Oh bella muerte!)

Se misericordiosa, llega rápido.

$[\ldots]$

Así en silencio en las proyecciones de los sueños, Vuelvo, reanudo, abro mi paso a través de los hospitales, El dolor y las heridas las pacifico disparando con mi mano, Me siento junto a la inquietud toda la noche oscura, algunos son tan jóvenes,

Algunos sufren tanto, recuerdo la experiencia dulce y triste, (Los brazos amorosos de muchos soldados sobre este cuello se han cruzado y descansan,

El beso de muchos soldados mora ya en mis labios barbudos.) (Whitman, 1865, versos 39-44 [... $59-65) .{ }^{19}$

Whitman gastó los años de guerra escribiendo y curando a soldados de ambos ejércitos. En la capital de los Estados Unidos, en Washington D. C., hubo más de 40 hospitales temporales donde el poeta, probablemente vio el interior de cada uno de ellos. Allí asistió a los médicos durante cirugías y amputaciones. Llevó dulces, tabaco y artículos de

19 “The Wound-Dresser", versos 39-44 [...] 59-65. 
papelería a los enfermos. Escribió cartas a los familiares de los soldados heridos. A veces transmitió buenas noticias, en otras más comunicó la triste muerte de los hijos (Loving, 1998). Escuchar, escribir, dar voz: estas acciones aliviaban a quienes necesitaran de la capacidad del escritor y voluntario.

Un lugar visitado frecuentemente por Whitman fue el hospital Armory Square. Dentro de sus once salas, se dedicó a observar y a curar, por mucho, los peores casos, las heridas más repulsivas, el sufrimiento más agudo, así como a las personas más necesitadas de consuelo. A ese sitio iba todos los días sin falta y muchas veces de noche, se quedaba muy tarde (Peck, 2015). Su figura avejentada, de barba y cabellos largos y canosos le hacían una figura confiable. Nadie interfería con su deseo de ayudar.

Whitman pensaba que su apariencia tranquilizaba a los heridos, así como al mismo personal médico. Él fue uno de los pocos civiles que estrechó relaciones con los cirujanos, administradores y enfermeras de los hospitales. La mayoría agradeció su presencia como una fuerza positiva en la moral de los soldados y él se dio cuenta de lo comprometido que estaba con sus pacientes. En distintos centros de salud, el poeta recogió material suficiente para crear versos y conocer la realidad del campo de batalla.

Whitman contempló en las enfermerías “[...] una serie de horrores y experiencias que le afectarían profundamente y orientarían su vida durante años” (Martín, 2003, p. 99). La atrocidad le hizo reconocer el esfuerzo de soldados y de involucrados por defender la causa de una nación. Sin embargo, la postura inicial ya no era la misma: la Unión ya no podía permitir mayor atrocidad a cualquier costo. Lograr la unidad democrática del país no se había perdido de vista. Así, el sentimiento del escritor cambió hacia una visión piadosa, filial y en busca de la reconciliación. 
Esta oración puede sustentarse con el pensamiento y las letras del presidente Lincoln. "Nosotros estamos aquí dedicados a la gran tarea que nos queda [...] ante nosotros están los cuerpos de quienes no habrán muerto en vano [...] y el gobierno del pueblo, por el pueblo, y para el pueblo, no perecerá de esta tierra.” (Hollinger y Capper, 1997, p. 475). Él entonó las siguientes palabras en 1863, en el cementerio de Gettysburg, para reconocer el esfuerzo de quienes habían dado su vida por el bien de la Unión y de la democracia. Dos estandartes que no debían perderse de vista para lograr los objetivos de la Unión.

Vuélvete, Oh, Libertad, porque la guerra terminó, De aquí a allá expándete sin dudar, barre el mundo, Aleja de las tierras la retrospectiva y graba las pruebas del pasado, [...]

Entonces gira y no te alarmes, Oh, Libertad, gira tu rostro eterno, Donde el futuro, mayor que todo el pasado, Se está preparando rápidamente para ti. (Whitman, 1865, versos $1-3[\ldots] 10-12) .{ }^{20}$

El desenlace de la guerra ocurrió a la par del voluntariado de Whitman -de 1863 a 1865-. Las fortalezas y las carencias de ambos bandos fueron clave para finalizar el conflicto: el número de habitantes y la situación económica. En 1863, los recursos del Norte soportaban mayor cantidad de voluntarios y soldados. Las actividades productivas no se detenían. Este aspecto parecía imposible para el lado opuesto. Las fuerzas confederadas sufrían reveses militares. Los estados del Sur eran incapaces de enviar soldados al frente y a la vez producir recursos para mantener la causa (Adams, 1979). Las dificultades internas y económicas redujeron las posibilidades de victoria para el bando sudista.

Los enfrentamientos duraron un par de años más. Las esperanzas de la Confederación se depositaron en una posible intervención de Gran Bretaña o Francia. Los del Sur creían que la falta de algodón afectaría la actividad comercial de estas dos naciones europeas. Eso haría

20 “Turn O Libertad". 
apoyarlos en la batalla. No sucedió así. Los sureños combatieron solos hasta el fin. Aunque las pérdidas humanas de la Unión se daban con un mayor volumen $-6,000$ hombres por hora- eso no mermó el avance hacia el Sur. Los confederados no podían detener los embates del Norte. (Jenkins, 2007). Aunque el conflicto duró un par de años más, la balanza se inclinaba a favor de la Unión.

Las fuerzas unionistas, lideradas por el general Grant, lograron -después de cuatro años - tomar Richmond. Ese golpe comenzó la debacle confederada. El 17 de febrero de 1865 cayó Columbia y Charleston. Las tropas del Norte avanzaban sin ninguna resistencia. Una semana más tarde, en Appomatox, Virginia, las fuerzas sudistas del general Lee se rindieron ante sus adversarios. No obstante, una de las últimas acciones del ejército del Sur fue el asesinato del presidente Lincoln el 14 de abril, en el teatro Ford. Las fuerzas confederadas fueron desintegradas en su totalidad para mediados de mayo. La Guerra Civil terminó con más de medio millón de vidas, y cuatro años de enfrentamientos.

Whitman escribió cuatro líneas referentes al asesinato de Lincoln. Esos versos reconocieron a un individuo admirado por el poeta. Las palabras del escritor hicieron referencia a un hombre capaz de defender los ideales de unión de los Estados Unidos:

Este polvo fue una vez el hombre,

Gentil, sencillo, justo y resuelto, bajo cuya mano cautelosa, Contra el crimen más sucio de la historia conocido en cualquier tierra o época, Se salvó la Unión de los Estados.

(Whitman en Reynolds, 1995, p. 447).

Whitman vio en Lincoln a un hombre de pueblo y representante de los ideales democráticos. De esa manera, la Guerra de Secesión disparó sus últimas balas y la voz del poeta sonó como testigo de aquel enfrentamiento.

Debería haber silencio en el campamento el día de hoy, Y los soldados han dejado las armas ganadas durante la guerra, 
Y cada uno con su alma meditante se retira para celebrar, La muerte de nuestro querido comandante."

(Whitman, 1865, versos 1-4). ${ }^{21}$

Walt Whitman pensó que la verdadera guerra nunca aparecería en los libros. No podría existir, incluso, ninguna palabra capaz de transmitir de forma fidedigna esas experiencias: "su historia [de la guerra y los soldados] no sólo nunca se escribirá, sus prácticas, minucias de hechos y pasiones, ni siquiera se sugerirán jamás." (Whitman en Peck, 2015). A pesar de los numerosos relatos periodísticos e históricos sobre las batallas, Whitman se dio cuenta de una verdad fundamental sobre la Guerra Civil: fue un encuentro profundamente violento captado verdaderamente solo por aquellos que lo vivieron de primera mano. Tal vez por esas palabras, él, la guerra y su obra eran un mismo ente.

${ }^{21}$ Véase "Hush'd be the Camps To-day", versos 1-4. 


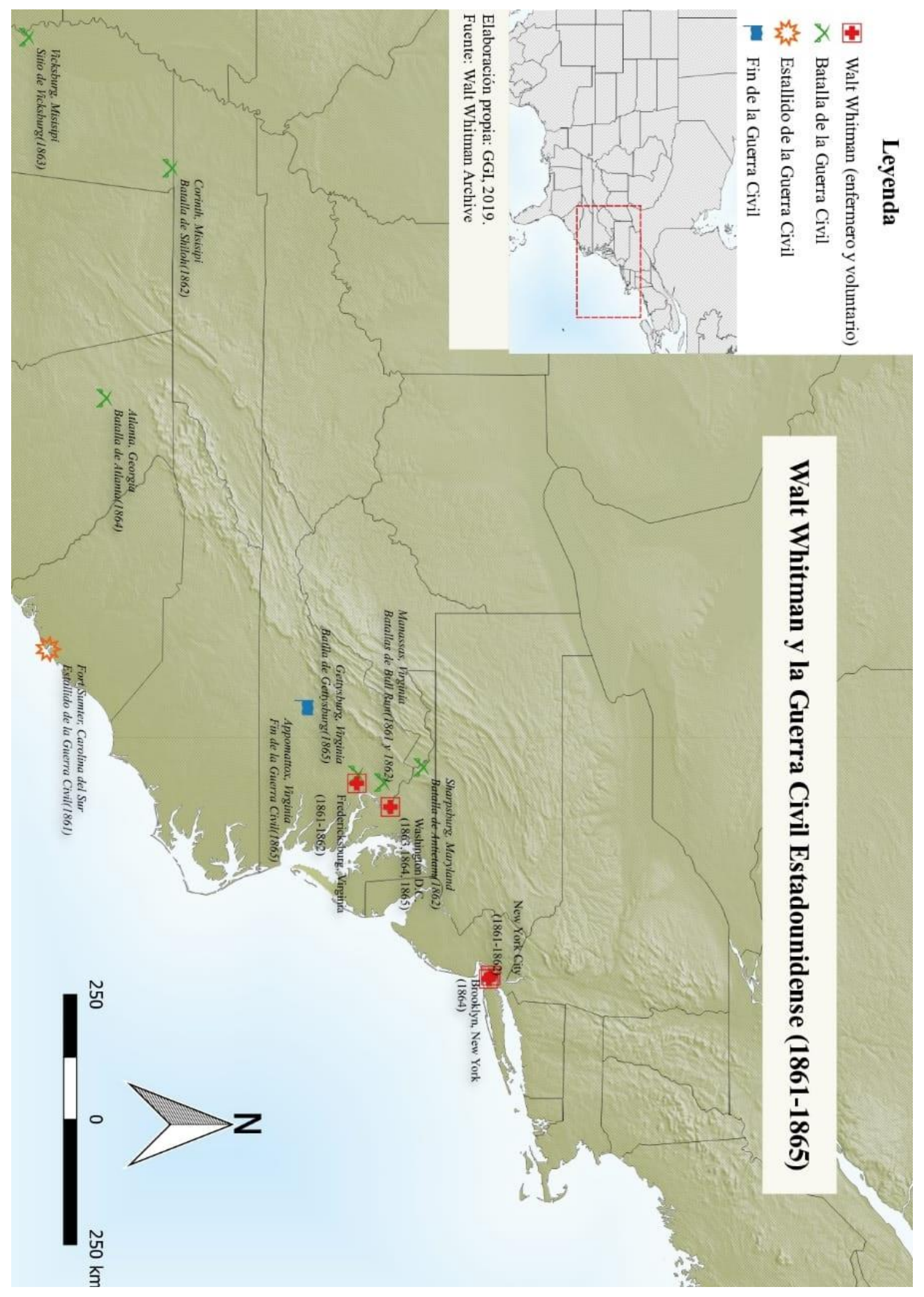




\section{Capítulo II}

\section{Whitman: poeta o historiador de la Guerra Civil (1861-1865)}

For the poet the Civil War became a marriage ceremony of sorts-between
him and his country-and his poignant wartime poems in Drum-Taps (1865)
a betrothal and spiritual renewal.

Jerome Loving

The war itself, with the temper of society preceding it, can indeed be best described by that very word convulsiveness.

Walt Whitman

La creación poética es más aún que la imagen de la creación del mundo: es la creación en sí.

Albert Béguin

El capítulo anterior guarda la comunión entre existencia e intelecto de un hombre inmerso en tiempos y espacios precisos. Walt Whitman forjó su obra, al igual que su rol como poeta, al entramar su vida con diversas situaciones nacionales. Absorbió su entorno -viceversa- para sustentar su voz ante los hechos. Con base en los momentos abordados, es posible rastrear experiencias individuales y colectivas para estudiar o recrear un fragmento en la historia de los Estados Unidos.

En esta sección, el objetivo yace en la obra de Whitman. Su trabajo merece atención especial pues representó la racionalidad de su realidad. Lo racional recae en la percepción del tiempo no como lo actual, sino como los momentos objetivos, exactos y válidos que orientan al ser humano en su actuar creativo (Pérez Cortés, 2013). Poeta y obra se adaptaron a las exigencias de su entorno para testimoniarlo. Al originarse en situaciones precisas, los versos significan la adherencia histórica entre el poeta y la realidad.

No basta con descubrir la correspondencia entre poeta-poema-realidad. Por esta razón, esta sección destaca la obra poética. La discusión debe circundar la obra del poeta durante el conflicto. Para después retomar la experiencia misma del escritor y su cambio de 
visión ante la crueldad y salvajismo de la guerra. Así también, apela al análisis de los versos a partir de tres propiedades útiles para la historia: la descripción, la expresión y la evocación. Los instantes poéticos creados por Whitman guardan propiedades e información útilenriquecedora de aquel tiempo.

Con base en este argumento, el trabajo de Whitman puede tratarse como una asignatura aparte. Desde la primera edición de Hojas de hierba, en 1855, el poeta buscó unir ideales - propios y conjuntos- con el mosaico histórico de su país. Ese poemario tuvo la intención de plantear y forjar el proyecto del "yo" como pieza de unión o reconciliación ante cualquier tipo de diferencia. La relevancia de ese libro se ha acumulado junto al interés de profesionales y curiosos del intelecto del poeta. No sólo su vida, su obra ha generado una gran cantidad de estudios, proyectos e investigaciones.

Hojas de hierba guarda su propia historia. Aunque representa un ícono de la literatura universal, su reconocimiento no fue inmediato. Whitman pagó y encuadernó de su bolsillo la producción de la primera edición. Se encargó de supervisar cada paso de la composición, distribución y recepción del poemario. A pesar del esfuerzo, la primera edición obtuvo tan pocas ventas como lecturas (Folsom y Price, 2007). La obra tenía un ideal arraigado, pero se vio opacado por la realidad política y social estadounidense. Conoció el rechazo, pero Whitman nunca se rindió para hacer notar su trabajo.

Sus Hojas resultaron de un proceso creativo de más de una década: después de haber sido maestro y reportero del panorama nacional. En ese lapso, Whitman conjuntó el periodismo, la ficción y los problemas sociales en un producto cultural con un enfoque sin precedentes. Envió copias a varios escritores conocidos, quienes hicieron caso omiso al trabajo. Sólo uno de tantos respondió: Ralph W. Emerson, con quien comenzó una relación de amistad y reconocimiento muto. 
A pesar del rechazo, la intención de Whitman era clara: sus versos ofrecían una identidad recíproca entre el individuo y su entorno. Como se mencionó en el primer capítulo, el poeta arraigó la idea de unidad nacional en sus poemas. Enfatizó la idea de equidad e inclusión. El protagonista de los poemas no parece un individuo; son masas, personajes relacionados entre sí por el simple hecho de pertenecer a un mismo territorio. Su "yo" concentraba la idea de un todo:

Traed a todas las razas, o castas, o generaciones, a expresarse a ellas mismas-personifiquen los objetivos generales de su creatividad y denles voz. [...] todo dentro de una escala más augusta-una hoja de hierba, de igual voz. (Whitman, 1855).

Además de la unidad, Whitman planteó en sus Hojas un concepto por demás complejo: la libertad. El poeta intentó definirlo como la autonomía del espíritu, la de sí mismo. No cabe duda que el propio "Canto a mí mismo" es un grito liberador por dejar ir opresiones, creencias, limitantes socioculturales: “[...] Creo en ti alma mía, mi otro yo no debe humillarse ante ti, / Y tú no debes ser humillado por el otro [...]" (Whitman, 1855, versos 82-83). Pero también ese poemario proclama una libertad de dimensiones nacionales.

Para Whitman, la libertad se alcanzaría con la democracia. En 1850, los Estados Unidos se llenaron de tensiones internas. Los mandatos nacionales contra las políticas estatales, la esclavitud, la expansión geográfica hacia el Oeste y la guerra con México -una década atrás—-resonaron con fuerza en la realidad y en la creatividad del poeta (Miller, 2009). El poeta no ignoró ninguno de estos hechos. Al contrario, creyó en la fuerza de su voz para cimentar la unidad nacional como tierra fértil para la libertad democrática. Sus Hojas tenían la responsabilidad de unir y liberar individuos, posturas y sociedades.

Ante el panorama secesionista, la voz de Whitman se alzaba con analogías. Su idea democrática la obtuvo de sus autores favoritos, Fanny Wright y Justus Liebig: "los átomos 
comparten un ciclo democrático de intercambio y aceptación permanente" (Reynolds, 1995, p. 326). La nación debía copiar tal interacción. En su obra, cuando el poeta se cantó a sí mismo, entonó sus deseos democráticos para unir a su país. La afinidad —social, sexual, política, racial e ideológica- debía matizar las decisiones separatistas y faltas de comunión.

Whitman no fue el único con ideas de comunión. Para el economista Henry Charles Carey (en Hollinger y Capper, 1997), existían dos sistemas arraigados en el país. Uno se encargaba de incrementar la producción de materia prima, de comerciar y emplear millones personas ajenas al territorio norteamericano. El otro se esforzaba por lograr sus propios productos y recursos, así como atraer a millones de personas para consumir esos productos. La falta de concordancia, así como una división de posturas, no permitían la misión nacional.

Tal objetivo apuntaba a establecer un propio gobierno sin divisiones de cualquier índole. Eso podía suceder si los bandos norteños y sureños limaban asperezas en beneficio de un bien común. A ese argumento no debe omitirse las palabras de Abraham Lincoln en 1854 (en Hollinger y Capper, 1997): "la unión-cordialidad de posturas debía crecer no como una necesidad, sino como un logro moral ante la extensión de algo controvertido e incontrolable.” (p. 463). El gobierno de un todo debía ser el mayor logro.

Al no lograr lo planteado, la unidad de los Estados Unidos corría peligro. Lincoln veía a las discordias como el mayor obstáculo de la paz y prosperidad nacional. En el "Discurso en Petoria, Illinois", el político arengó a no perder lo dictado por los padres de la patria: "Que el Norte y el Sur-todos los estadounidenses-los amantes de la libertad-se unan a la gran y buena obra. Si hacemos esto, no solo habremos salvado la Unión; nos habremos salvado a nosotros mismos y para siempre.” (en Hollinger y Capper, 1997, p. 466). La idea de un gobierno democrático compartía perspectivas similares a las del poeta. 
El trabajo de Whitman buscó establecer un proyecto poético y político. Sus intenciones se marcaron en cada verso, pero la obra no dejaba de tener un acento utópico. La realidad superaba a los ideales. Reynolds (1995) aseguró que Whitman hizo todo lo posible por ser escuchado, "para atraer lectores con sus letras" (p. 310). La comunión nacional planteada por Whitman quedaba con un gran signo de interrogación. Sus Hojas y su idea del “yo" eran opacadas por la realidad nacional.

Whitman escribió líneas poderosas en intención, pero débiles en recepción. Su voz y poemas cargaban optimismo y claridad, aunque carecieron de lectores y de entendimiento. Toda la obra, incluido el prefacio, fundamentaba la fe y la presencia del poeta como un ser único y capaz de restablecer el orden nacional. En 1855, Whitman sentía que los Estados Unidos lo necesitaban, tanto como él a su país. De ahí su seguridad en afirmar, en múltiples líneas: la nación y él debían absorberse de manera afectiva y mutua.

La falta de interés no sólo radicaba en los lectores. Whitman hizo y distribuyó su obra porque las editoriales no se arriesgaban a producir tirajes del poemario. Él no ignoró este hecho; al contrario, comenzó una tarea ardua: actualizar su obra. A la primera edición de Hojas de hierba, le siguieron dos más, una en 1856 y otra en 1860. Pero ambas tuvieron la misma suerte que su predecesora. Su voz alcanzó un tono débil como para establecer la idea de unidad, libertad y democracia.

Whitman no logró ser reconocido como el poeta nacional en las primeras ediciones de su obra. Sin embargo, su popularidad aumentó: construyó su legado con la actualización y adiciones de escritos a este poemario. Este incremento sucedió después de la Guerra Civil. El conflicto otorgó otra dimensión a sus escritos. A partir de este hecho crucial en la vida estadounidense, el poeta articuló —aún más - sus ideas con la realidad. La actualización lo benefició de manera particular: fue leído desde otra perspectiva de la vida nacional. 
Por esa razón, Hojas de hierba tiene un antes y un después. Lo primero se compone de la afirmación y búsqueda de la unión, de la liberación individual y espiritual, así como del ideal democrático. El después surge tras la Guerra de Secesión. El enfrentamiento puso en tela de juicio todos los ideales no sólo del poeta, sino de la nación misma. El después del poemario comprende los poemas durante la guerra. Redoble de tambor (1865) contiene las esperanzas de una nación cimbrada, así como las experiencias propias del poeta.

Redoble de tambor captura instantes de la vida nacional estadounidense. Mair Mullins (1999) consideró a ese conjunto de poemas testimonios donde se concentran experiencias individuales y colectivas: "En ellos no sólo se escucha el tambor, el avance de los ejércitos o el terror en el campo de batalla. En los versos también se congelan la camaradería, el deseo, el afecto y la idea de unión" (p. 4). El sonido del tambor llevó al trabajo de Whitman hacia otros alcances. No bastaba con la idea y los deseos de un hombre, el poemario servía como una memoria de la historia nacional.

Esos escritos guardan la visión de un hombre que, junto con otros, participó y experimentó los derroteros de la Guerra de Secesión. Aunque sólo introduce la mirada del poeta, los instantes del apartado aportan información al respecto de un hecho histórico. "Redoble puede escucharse como un collage de testimonios: de la valentía de los soldados, de los observadores del conflicto, del salvajismo de la guerra (O’Neil, 2016, p. 82)." La percusión guarda la voz del poeta para testificar el panorama no sólo de los hechos, sino también de los actores y de quienes padecieron e hicieron eco de sus horrores.

La Guerra Civil escrita con los versos de Whitman también parece un tema investigado. Cristanne Miller, en su artículo "Drum Taps: Revisions and Reconciliation”, resalta las diferencias entre la obra de Whitman con los demás poetas sobre el conflicto. Los escritores postconflicto no podían despojarse de una nostalgia regionalista. El Norte y el Sur 
de los Estados Unidos idealizaban una harmonía racial, política e ideológica. Ésta había sido quebrantada al estallar las hostilidades. (Miller, 2009). Las posturas de los escritores omitían conflictos y discordias acumuladas antes de la guerra.

Además, Miller analiza y ofrece un panorama de cómo se escribió la poesía sobre el conflicto interno. Esos documentos se dividieron en dos categorías. Los poetas sureños lamentaban la muerte de la Confederación, aunque no abandonaban los ideales por los cuales lucharon. Del otro lado de la moneda, los poetas norteños, mostraban una faceta amena -Whitman también debe estar dentro de la categoría一: de condenar la esclavitud y la traición sureña antes y durante la Guerra Civil, a proponer un proyecto conciliador. De este trabajo pretendo retomar el último punto: la idea de reconciliación nacional con base en los poemas de Whitman.

Redoble se incluyó en ediciones posteriores de Hojas, siendo un apartado titulado de manera distinta. Esto marcó una diferencia radical con los primeros trabajos de Whitman. Esa sección ya no reflejaba la concepción inicial de unión entre naturaleza, individuo y nación; aunque la democracia continuó siendo un logro a perseguir. Más bien, Redoble planteó una diferencia entre las obras del propio poeta: el protagonista. El personaje clave de la poesía deja al "yo" para convertirse en soldados, voluntarios, veteranos, ciudades o testigos de las batallas.

Los cambios en las letras de Whitman establecen puntos de partida. Uno de ellos debe concentrarse en el contexto de la obra. La tesis de Laura López Peña, The Role of the Poet in the American Civil War: Walt Whitman's Drum Taps (1865) and Herman Melville's BattlePieces (1866), recupera el tiempo y el espacio de una nación en guerra. Ese episodio en la historia estadounidense ocasionó un proyecto de reconciliación entre individuos y comunidades. "La literatura, la poesía en específico, se colocó como un estandarte para lograr 
la unión.” (López Peña, 2008, p. 4). Esto confirma un punto tratado en este documento: el valor poético no omite la importancia histórica.

Redoble de tambor modificó los ideales y alcances de la poesía de Whitman. Esta obra no sólo cimentó las oportunidades del poeta, sino de toda la nación para responder al llamado de la unión. La devoción de Whitman por su país forjó una responsabilidad de escribir y testimoniar los hechos de la guerra. López Peña no expuso algo ignorado por otros especialistas, aunque sí rescató la relevancia y el contexto de lo escrito: la transición de ideales en realidades.

La autora plantea un cambio en la percepción y en la escritura del Redoble. Esta idea parte desde la defensa del conflicto. Tanto la nación como Whitman asumieron a la Guerra Civil como una catarsis estadounidense necesaria. Después, la nación resurgiría poderosa, unida y verdaderamente democrática. Tal visión cambiaría a partir de 1862. En ese año, Whitman tuvo contacto con la realidad del campo de batalla, con los estragos y daños de la guerra. La visión inicial cambió tras observar la realidad. Así, el poemario concentra una experiencia individual cambiante tanto de perspectiva como de entonación.

Este cambio de perspectiva también ha sido estudiado. Andrew Pearcy escribió la tesis intitulada “Walt Whitman's Changing Perceptions of the Effects of the American Civil War and its Impact on his Poetry”. En esa investigación, aunque el título lo dice casi todo, los argumentos del autor muestran profundidad en esos cambios. El trabajo va directo al grano: los primeros poemas en Redoble gozan de patriotismo y validan una guerra rápida y sin consecuencias negativas. Pero a la mitad del poemario, el tono de la poesía cambia a un optimismo anulado por los hechos durante conflicto (Pearcy, 2013). La claridad argumentativa del autor permite observar los cambios en el trabajo de Whitman. 
Este trabajo ahonda en la postura y en la manera de escribir del poeta. Al inicio de la Guerra Civil, Whitman tenía un ideal patriótico y positivo hacia el conflicto. Las vidas de unos cuantos soldados era un precio justo por pagar. Tal visión cambió por completo. Para mostrar una parte de esas modificaciones, Pearcy se concentra en sólo tres aspectos plasmados en los poemas de Whitman: en la vida del mismo, en los cambios militares y en la perspectiva civil hacia la guerra. De tal manera, la tesis no concentra sus esfuerzos en analizar al autor, sino a los elementos establecido en su obra poética.

Tras analizar los poemas creados durante la guerra, Pearcy concluye en la complejidad de la figura de Whitman como en la de sus escritos. Redoble de tambor captura la esencia de la población, la milicia y la nación estadounidense. Aunque algunos de los poemas lucen ambiguos, el poeta pudo crear, desde su propia experiencia, una serie de retratos listos para ser recreados por cada lector. La beligerancia significó un parteaguas en la historia estadounidense y en la poesía de Whitman.

Uno de los instantes con mayor atención para varios investigadores y académicos, sin duda, se concentra en el paso de Whitman por las enfermerías. La participación del poeta durante el conflicto no fue en el campo de batalla, sino en el de sanación. Allí sucedió una transformación en su manera de percibir y escribir los hechos. Karilyn Lindeen (2016) dedica el cuarto capítulo de su tesis, Walt Whitman and the American Civil War: from de Wound Dresser to Good Gray Poet, a señalar estos cambios en la persona. Su figura transcurrió de ser sólo un enfermero a ser conocido como "El buen poeta gris".

A partir de darse a conocer "El curador de heridas", Whitman jugó con las analogías. Tomó el papel tanto de sanador de soldados, como de una nación entera. Con esta responsabilidad en su espalda, poeta y poema capturaron imágenes vívidas de un hombre avejentado mientras sirve como enfermero o como mero espectador de la muerte silenciosa. 
Los años del poeta en los sanatorios cambiaron su vida de una manera significativa. Allí encontró su verdadero llamado como escritor; abrazó la valentía, el dolor y la tristeza experimentada por su nación durante la Guerra Civil. Así también plasmó cambios propios y ajenos de mentalidad y emociones.

Lo discutido señala la discusión de este capítulo. Los estudios sobre Redoble circundan problemáticas y argumentos: la experiencia del poeta durante el conflicto; el patriotismo y el júbilo de los primeros poemas; así también, el cambio de tono en los poemas parece algo difícil de ignorar. Estas ideas guían la mayor parte de las investigaciones sobre el trabajo del poeta. Tras la revisión, mi propuesta comienza. Busco retomar algunos de los argumentos anteriores - la experiencia misma de Whitman y su cambio de perspectiva-; no obstante, también apelo al análisis de los versos a partir de tres propiedades útiles para la historia: la descripción, la expresión y la evocación.

Con esta tercia analítica pretendo elaborar una relectura de Redoble de tambor. Esto me permite observar los instantes consagrados por el poeta sobre el conflicto, los cambios y los estragos de la Guerra de Secesión. Ese poemario guarda la visión de un hombre que puede aportar información histórica. Si esos poemas guardan un collage de testimonios, de valentía, así como del salvajismo de la guerra; de la misma manera, esta obra literaria recoge la voz de los soldados, así como la de los contempladores del conflicto. En este mosaico salen a flote las posturas a nivel individual como social, respecto de la beligerancia.

Al tener claro el objetivo anterior, procuro demostrar la forma en la que el poeta y el poema describen, expresan, y evocan lo convulso de la guerra estadounidense. "Whitman había sido testigo de cuatro años de guerra y de un sinfín de vidas desperdiciadas. El poeta pudo emocionarse al principio con los objetivos de la misma, pero finalmente se cansó de todo el trauma y la angustia generada por los episodios de muerte y destrucción”. (Loving, 
1998, p. 476). La acción poética enseña la realidad de un hombre, siempre y cuando esté arropada por otros testimonios. Las creaciones de Whitman deben interrogarse y arroparse de los hechos históricos.

Este segundo capítulo invita al encuentro de un hombre con su propio lenguaje, a los instantes poéticos de su obra. El Redoble valida la memoria de un hecho plasmado en palabras. Whitman elaboró su verdad como un representante verdadero de su pueblo. Él elaboró esta realidad desde su propia perspectiva y en forma de un poema que sirve para recrear o ampliar lo sucedido durante la Guerra Civil. ${ }^{22} \mathrm{Su}$ poemario guarda instantes cristalizados, capaces de acercar a los lectores al lenguaje, al poeta, a la sociedad, y a un periodo de la historia misma de una nación.

\section{Escuchar los redobles del tambor}

La poesía forma parte del análisis histórico sólo si mantiene una relación inquebrantable con el poeta y la realidad. Este argumento se desarrolló en el primer capítulo de la investigación. Los destellos biográficos sobre Whitman revelaron la unión entre vivencias, contexto nacional y versos. El siguiente paso apunta a indagar sobre la Guerra de Secesión a partir de Redoble de tambor. Ese poemario debe leerse con una intención inquisidora y crítica para encontrar la riqueza histórica resguardada en los versos.

Whitman creó ese libro a partir de su perspectiva y con base en los hechos ocurridos durante la guerra: “[...] no se mantuvo alejado, como Herman Melville, o no sólo criticó las

\footnotetext{
${ }^{22}$ Esta es una referencia al trabajo y pensamiento de Martín Heidegger (1973): “Cuando el poeta queda consigo mismo en la suprema soledad de su destino, entonces elabora la verdad como representante verdadero de su pueblo." (p. 123).
} 
causas y los hechos, como Stephen Crane.” (Öz, 2015, p. 32). ${ }^{23}$ Estuvo inmerso en las acciones, las posturas y los giros de las hostilidades. Esto le llevó a argumentar que la guerra y sus poemas eran un mismo ente. Por esas razones, su Redoble logró evidenciar y contener distintas memorias sustentadas en testimonios, actores y hechos del conflicto.

Escuchar el redoble del tambor brinda información histórica de la Guerra Civil. A pesar de la existencia de un sinfín de sonidos, pretendo escuchar sólo tres. El primero habla de la pertenencia individual y colectiva guardada en los poemas. Aunque fueron escritos por una persona, responden a distintos marcos sociales. El segundo versa sobre el infierno terrenal visto por el poeta. La guerra y sus horrores en el campo de batalla sólo quedan en referencias y metáforas. El tercero muestra la perspectiva cambiante de la beligerancia. No únicamente en el escritor, sino en la nación entera. Con tres golpes puede encontrarse mayor información para recrear un hecho histórico.

¡Drum! El primer golpe del tambor resuena en los marcos sociales. Esa idea se resume en una frase: los poemas de Whitman guardan una perspectiva individual, y a la vez colectiva, de las hostilidades. Fueron creados con "nociones comunes que reconstruyen una realidad a partir de datos en conjunto; ésos que formaron parte de una misma sociedad." (Halbwachs, 2004, p. 34). Cada poema de Redoble posee una perspectiva personal, aunque conjunta sobre algunos momentos ocurridos durante la Guerra Civil.

Los marcos sociales son el punto de partida de todos los actos individuales de la memoria. Como argumentó Ute Seydel (2014), tales marcos se transforman de manera lenta para ser la base de los recuerdos individuales. Cada persona interactúa, proporciona fechas,

\footnotetext{
${ }^{23}$ El primero estuvo alejado del conflicto, el segundo nació mientras las hostilidades sucedían. Ambos escritores escribieron poemas sobre la Guerra Civil años después y con una visión más crítica sobre lo sucedido.
} 
nombres, nociones, patrones de experiencia, así como formas de razonamiento y pensamiento. Estos elementos se suman a los de otras personas para poder reinterpretar y ordenar los sucesos. Así se crea una memoria conjunta —coherente- sobre algún hecho. Una memoria individual pierde valor si no se completa o compara con la de otros.

Por la razón anterior, los actos individuales de la memoria nunca concentrarán la totalidad del pasado. Los recuerdos de una persona representan sólo un sentir de la realidad; son respuestas a una percepción, emoción o sentimiento. Cada recuerdo debe complementarse o contrastarse con los marcos de la memoria colectiva, de los miembros de una comunidad. Esto lo llamó Halbwachs "la historia de las representaciones" (en Seydel, 2014, p. 198), ya que cada sujeto recuerda distintas peculiaridades sobre actores o acontecimientos en tiempos y espacios similares.

Walt Whitman escribió desde varios marcos sociales determinados por la Guerra Civil. Su Redoble de tambor corresponde al mundo de las enfermerías, de los soldados heridos, de los dramas familiares. Su obra pertenece a ciertos entornos donde puede contrastarse y complementarse con otras fuentes. Su trabajo plasmó lo rememorado, lo visto y lo escuchado en algunos escenarios de la beligerancia. Sus poemas poseen una riqueza histórica pues contienen memoria individual cimentada en la comunicación e interacción con otras realidades.

Una de esos marcos sociales - o realidades - se localiza en la incertidumbre familiar. Como muchos de los habitantes de los Estados Unidos, Whitman leía el periódico y revisaba las listas de heridos después de las batallas. Un día de diciembre de 1862, se sorprendió al encontrar el nombre de "G. W. Whitmore" en la lista de bajas de Fredericksburg. Su temor se disparó ante la posible confusión del nombre de su hermano: George Washington Whitman. El poeta comenzó una odisea para encontrarlo y así desechar cualquier duda: lo 
buscó en los casi cuarenta hospitales de la capital estadounidense, tomó trenes y diligencias militares para llegar al frente de batalla y ver si George aún seguía vivo.

La travesía terminó cuando vio una herida superficial en la cara de su hermano. Tras el alivio, Whitman se horrorizó al ver algo difícil de olvidar: afuera de una mansión convertida en hospital, se encontró con una carreta cargada con pies, piernas, brazos y manos. Esas extremidades habían sido amputadas durante cirugías (Folsom y Price, 2007). La imagen atormentó la sensibilidad del poeta. En sus Hojas de hierba, años atrás, había celebrado la belleza del cuerpo; había categorizado a los brazos y las piernas como extensiones del alma. Whitman decidió convertirse en las partes faltantes de los soldados mutilados. En ese momento, eligió comunicar buenas o malas noticias.

El poema "Viene desde los campos, Padre" menciona los miedos de quienes esperaban noticias en casa. Los versos evocan el marco social de la incertidumbre familiar. Esa vivida no sólo por Whitman mismo, sino por padres, madres y hermanos de los soldados. En el texto, el poeta representó una escena común en tiempos de guerra: la muerte toca la puerta de los hogares, de las familias de los combatientes. Aquel poema lo protagoniza una carta que impacta la rutina familiar. Esa epístola, escrita por un ajeno - por alguien como Walt-, notifica lo sucedido tanto en la batalla como en los hospitales.

Viene desde los campos, padre, aquí hay una carta de nuestro Pete,

Ven a la puerta de entrada, madre, aquí hay una carta de tu querido hijo [...]

Abre el sobre rápidamente

Oh, esta no es la letra de nuestro hijo, pero su nombre está en el remitente:

¡Oh, una mano extraña escribe por nuestro querido hijo, oh, alma de madre herida!

Todo y nada ante sus ojos, ella parpadea, sólo capta las palabras principales,

Sentencias rotas: herida de bala en el pecho, emboscada a la caballería, llevados al hospital,

No es el mejor momento, pero pronto estará mejor. 
[...]

Pero la madre necesita mejor información

Ella, con su forma delgada, actualmente viste de negro,

Durante el día, las comidas no se tocan, luego, por la noche, duerme a ratos, a menudo despierta,

En la medianoche llora, anhela profundamente,

Oh, para que ella pueda retirarse

A seguir, a buscar, a encontrarse con su querido hijo muerto

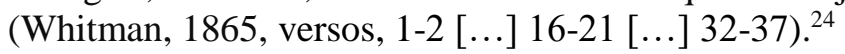

Whitman puso en perspectiva su propia tragedia con las de muchos habitantes en los

Estados Unidos. Tras ignorar los hechos y salir a buscar a George, intensificó su empatía con

la de otras familias. Se puso en los pies de la catástrofe y las pérdidas humanas. Incluso, al verse lejos de su madre y hermanos, su actividad epistolar se volvió sin precedentes. De 1862 a 1865, escribió 486 cartas dirigidas a su familia, a soldados atendidos por él y dados de alta, así como a parientes de los militares. Al casi perder a su hermano, le ayudó a evidenciar las tragedias familiares, así como los estragos del conflicto.

No sólo la incertidumbre familia marcó sus letras. Otro marco social, donde los poemas enriquecen a la historia de la Guerra Civil, pertenece a la actividad dentro de hospitales y enfermerías. Walt Whitman no participó de manera directa en los enfrentamientos. Sus experiencias de guerra las tomó de soldados convalecientes en los centros de salud. Adquirió memorias individuales para adaptarlas en sus creaciones poéticas. Por supuesto que todos esos recuerdos no pertenecieron a un combatiente, sino a todos los atendidos por él.

Sus biógrafos coinciden que Whitman asistió entre 80 mil y 100 mil heridos en tres años. La mayoría de los hospitales en Washington tenían techos de madera, eran de un piso, y contenían camas contiguas para atender a los enfermos. Casi todos los días, en sus horas libres, el poeta recorría esos lugares, consolaba a los pacientes y ayudaba a los médicos o

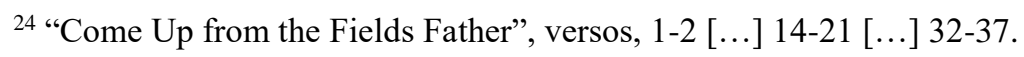


enfermeras. Sus horarios le permitían llegar desde el mediodía hasta las cuatro de la tarde y a veces de seis a nueve de la noche (Reynolds, 1995). Pasó la mayor parte del tiempo en el Armory Square, sitio donde arribaban los peores casos.

En los nosocomios, Whitman presenció el sufrimiento de magnitud incomparable en la historia nacional: "Más estadounidenses murieron y resultaron heridos en la Guerra Civil que en todas las demás guerras juntas. Las cifras nefastas finales fueron más de 610 mil muertos y 425 mil con heridas incapacitantes.” (Reynolds, 1995, p. 425). El poeta llenó cuadernos, cartas y poemas con descripciones de soldados afligidos, con heridas o traumas difíciles de entender. Su experiencia en las enfermerías refleja otro tipo de realidad fuera del frente de batalla o de las diferencias políticas e ideológicas de la guerra.

De esas vivencias, su poema más relevante es "El curador de heridas". En ese texto se lee la consciencia y el compromiso del poeta por cuidar enfermos y heridos, la "enseñanza más trascendental en su vida." (Siles, 2015, p. 13). El marco social dentro de los centros de salud se lee en cada verso de "El curador". Desde su propia presencia en los hospitales: "Viejo ya, y encorvado, me rodea, al llegar, caras nuevas, / y me retraigo al pasado para responder a los niños" (Whitman, 2019, versos 1-2); hasta la manera de interpretar el silencio emanado por los jóvenes heridos:

$[\ldots]$

Amputada la mano, del muñón del brazo

Retiro las hilachas llenas de coágulos, quito la escara, y lavo el pus y la sangre.

El soldado ladea la cabeza en la almohada.

Tiene los ojos cerrados, está pálido, no se atreve a mirar el muñón sangriento:

Aún no lo ha mirado.

Curo una herida en el costado, profunda, muy profunda;

Sólo durará uno o dos días más: ved el cuerpo debilitado, consumido, Ved el rostro lívido. [...]

(Whitman, 2019, versos 45-52). 
El trabajo de Whitman en el hospital se ha descrito constantemente. Su abrumadora rutina, los riesgos de su propia salud, incluso su vida homosexual, han sido retomados por expertos. Sin embargo, una idea queda en el tintero: ¿qué otras experiencias individuales y colectivas quedaron guardadas en su poesía? Su visión del hombre común, su necesidad de una familia ideal, la relación entre camaradas, son algunos temas que merecen atención por parte de los interesados en la vida y obra del poeta.

De este primer redoble se escucha a Whitman escribir en soledad, bajo la luz de la luna o ante las llamas intermitentes de una vela. No obstante, sus letras guardan las memorias de hechos donde él no era el único implicado. Al buscar a su hermano y al participar como enfermero voluntario, formó parte de las nociones comunes, de las distintas realidades, de la Guerra Civil. Con base en los hechos y en sus experiencias, encontró datos en común para reconstruir y asociar imágenes o recuerdos. Su trabajo testimonia su propio sentir, así como el de diversas personas golpeadas por el conflicto.

Sus palabras guardan diversas historias no para agotar el sentido de los poemas, sino para alimentarlos. Los versos de Whitman contienen una experiencia individual arraigada a una realidad común —nunca estamos solos, aunque la soledad intente abrazarnos-. En el Redoble del tambor, el poeta plasmó su perspectiva de los hechos, desde su interacción con los soldados, con quienes participaron en las batallas, o con quienes esperaban en casa. Estableció testimonios y datos en común de donde estaba inmerso.

¡Drum! Retumba el tambor por segunda vez: los poemas de Whitman hablan sobre un infierno terrenal percibido en todas las realidades. Además de los marcos sociales, de situaciones específicas, su obra también responde al pensamiento en común sobre la Guerra Civil. Es decir, ya no son eventos aislados como las tragedias familiares, el sufrimiento de 
los soldados o la rutina en hospitales, sino como un elemento compartido por uno y por todos. Una de esas ideas transmitidas fue la de asemejar a los años de guerra con la imagen del averno.

Whitman obtuvo ese pensamiento gracias a la lectura y análisis de La divina comedia, además de una perspectiva individual y colectiva de los hechos nacionales. En 1862, no sólo buscó a George, también compró, leyó y analizó aquel libro. Escribió -donde hacía los borradores de sus poemas- varias notas sobre los versos de Dante (Matthews, 2014). Mientras la nación pasaba por un momento convulso en su historia, Whitman sujetó al poeta medieval en su mente. El infierno dantesco influyó de manera directa en el estilo y los objetivos de Redoble.

La primera parte de la Comedia, el infierno, metaforiza muchos de los horrores en el mundo antiguo y en la época medieval. Redoble contiene una épica similar adaptada al frente de batalla y a los estragos de la guerra. Pero quizás el objetivo de la obra de Dante significó lo más atractivo para el estadounidense: el "triunfo global del republicanismo, así como de un nacionalismo encarnado.” (Matthews, 2014, p. 36). Whitman se ayudó de aquel texto para crear versos y metáforas similares en estilo y contenido.

Si hubo una constante en la Guerra Civil fue su extrema violencia. Confederados - de uniforme gris - y unionistas - vestidos de azul- se enfrentaron en largas batallas con un número de bajas considerables. Tras las hostilidades de Antietam, en 1862, en un día, fallecieron más de 3000 soldados. En Shiloh, en 1863, más de 20 mil hombres fueron muertos, heridos o capturados. Los números crecían y superaban las bajas “[...] en todos los conflictos que involucraron a los Estados Unidos en el Siglo XIX.” (Pani, 2016, 135). Los estragos, el terror y las pérdidas humanas en el conflicto le dieron a Whitman una razón suficiente para asemejar la realidad con las metáforas dantescas. 
La situación nacional lucía tal y como el averno. Ese lugar caótico y lleno de sufrimiento, no distaba de las situaciones originadas por la guerra. Además, la muerte encarnada en el frente de batalla y en los hospitales no podían ignorase. Whitman encontró una medida de inspiración y relación poética que lo ayudó a plasmar sus vistas a hospitales o enfermerías. La Comedia, además de su vida como enfermero, le brindó imágenes de violencia desproporcionada, dignas de pertenecer a cualquier círculo del infierno dantesco.

Lo que vi en el campamento en un amanecer borroso y gris, Al salir muy temprano de la tienda, sin haber dormido,

Y caminar despacio, al aire fresco de la mañana, por el sendero que bordea el hospital de campaña:

Tres cuerpos en sendas camillas, desatendidos, abandonados, Tapados con mantas de lana, grandes y parduzcas, Grises y pesadas, que los envuelven, que los cubren por entero. $[\ldots]$

Luego, al tercero, con cara ni de niño ni de hombre, que trasluce serenidad, como hecha de hermoso marfil, entre blanco y amarillo.

Muchacho, creo conocerte: esta carta se me antoja la del propio Jesucristo,

Muerto y divino y hermano de todos, que aquí yace otra vez. (Whitman, 2019, 1-6 [...] 13-15). ${ }^{25}$

Whitman adaptó esos círculos a sus propias creaciones poéticas. "El sitio donde nos encontramos no era como las alamedas que conducen a los palacios, sino que por el contrario, parecía una caverna de mal piso y poca luz." (Dante, Canto XXXIV). Las experiencias e imágenes en el campo de batalla - relatadas por los soldados y descritas en Redoble- le parecieron "[...] una especie de infierno continuo, desgarrador y omnipresente” (Matthews, 2014, p. 52). Los enfrentamientos y el averno compartían oscuridad perpetua, donde nada se reconoce, donde se está a merced de la supervivencia o la suerte.

Whitman reinterpretó al inferno con base en experiencias individuales y colectivas durante el conflicto. Desde los hospitales, conoció a la guerra de primera mano. La representó

\footnotetext{
${ }^{25}$ Véase el poema "A Sight in Camp in the Daybreak Gray and Dim”
} 
con palabras llenas de acentos humanos y emotivos, muy distintos a los que la prensa relataba. Las experiencias infernales vividas por el personal militar y médico, le parecían hechos ignorados o enterrados en la oscuridad del olvido. Su tarea fue escribir de manera “espontánea y compulsiva” (Martín 2003, p. 100), pero comprometida en registrarla. Al poeta le quedó claro que la situación nacional se parecía mucho a un inferno terrenal.

La lectura de la Comedia, le sirvió a Whitman para comenzar a metaforizar la idea de unidad nacional, no sólo la de los horrores. Asoció a la Guerra Civil con un atentado a la civilización. Este pensamiento no era exclusivo. La historia nacional sufriría un retroceso si la Unión perdía la guerra. La derrota significaría un problema político e histórico que Whitman encontró de forma elocuente en escenas a lo largo del infierno. Los hechos de los años 60 se empalmaban a su lectura de la obra dantesca.

Los Estados Unidos debían pelear por conservar su unidad. Los norteños defendían tal causa. La idea dantesca también apelaba a la idea gracias a la presencia de Dios. Los traidores de la patria, los sureños-confederados atentaban contra ella y debían yacer al fondo del infierno. Los traidores de la divinidad y la nación se encontraban en el último círculo junto a Judas, Bruto y Casio. El primero vendió a Jesús. Los otros dos asesinaron al César para amenazar la estabilidad del imperio Romano (Dante, Canto XXXIII). Esas metáforas, le brindaron a Whitman ejemplos poderosos sobre historia, teología, guerra, así como las amenazas a toda la nación.

El ultimato hacia una división irreparable ocasionó en Whitman una retórica militante y patriótica. La idea divisoria no podía ser omitida, ni evadir la influencia dantesca en sus poemas. Su voz poética, aunque consciente de las ideas secesionistas del Sur, también mediaba la situación entre los bandos enfrentados. Su postura nunca estuvo implícita o a 
favor de las causas norteñas, aunque en la mayoría de sus poemas había una glorificación hacia ciudades como Manhattan o hacia batallones neoyorkinos.

Cuarenta años llevaba viendo desfilar a los soldados en mi ciudad,

Cuarenta años de exhibición, hasta que, de pronto, esta ciudad fecunda y turbulenta, esta dama,

Insomne entre sus barcos, sus casas, su incalculable riqueza,

Rodeada por un millón de hijos, súbitamente,

En plena noche, al recibir noticias del Sur,

Dio un puñetazo en el suelo, enfurecida.

Una sacudida eléctrica: la noche la sostuvo,

Hasta que, al amanecer, con ominoso zumbido, nuestra colmena liberó

$[\ldots]$ sus miríadas

¡Guerra! ¡Avanza una raza en armas! La batalla es bienvenida: ya no hay marcha atrás.

¡Guerra! Ya dure semanas, meses o años, una raza en armas avanza para darle la bienvenida.

¡En Marcha, Mannahatta!, ¡Merece, oh, un canto digno!

¡Se acerca, oh, una existencia viril en los campamentos!

(Whitman, 2019, versos 11-18 [...] 46-50). ${ }^{26}$

Aunque sus letras parecían evidentes, Whitman no apoyó a la causa norteña o sureña de manera rotunda. Al contrario, su voz poética fue mediadora: "a diferencia de otros autores no aparece en estos poemas la guerra como una cruzada para erradicar la esclavitud del Sur y vengarse moralmente de él [...].” (Martín, 2003, p. 97). Defendió una idea con claridad: la guerra sólo afectaba a la nación por igual. La mejor solución era abandonar ese infierno y avanzar hacia la vía democrática. Llegar a ese objetivo podría unir, a través del amor, cualquier diferencia o neutralizar las diferencias que ponían en duda la grandeza de los Estados Unidos.

Tras la matanza se alzó, profética, una voz.

No perdáis el ánimo: el afecto resolverá los problemas de la libertad.

(Whitman, 2019, versos 1-2). ${ }^{27}$

\footnotetext{
${ }^{26}$ Léase el poema "First O Song for a Prelude"

27 El poema intitulado "Over the Carnaje Rose Prophetic a Voice", habla precisamente del argumento desarrollado en este apartado. Tras la matanza y la catástrofe, sólo la unidad y la resolución de las dificultades podría traer un próspero desenlace de unión y democracia a los Estados Unidos.
} 
Los argumentos anteriores, sólo esbozan un trabajo pendiente sobre la relación intelectual entre Whitman y Dante. Lo explorado hasta este momento habla de la guerra escrita desde las experiencias en el campo de batalla y asimilada como un terreno infernal imposible de negar. También muestran que no sólo los hechos y personajes nacionales influyeron su pensamiento. La idea de nacionalismo o unidad nacional en Dante determinó su postura ante las hostilidades.

Lo cierto es que Whitman intentó plasmar, de una forma fidedigna, los hechos de la guerra. Recurrió al infierno para representar los horrores y la violencia de una forma poética. Ese lugar, le ofreció estrategias para representarla y relacionarla con la memoria histórica, social y psicológica del conflicto (Matthews, 2014). Los poemas en Redoble trataron de adaptar las visiones dantescas a un sentimiento nacional capaz de solucionar cualquier problema. Los escritos de Whitman durante la guerra no sólo se generaron a partir de su compromiso con periódicos o cuidados en los hospitales. Sus versos se moldearon a partir de la literatura clásica; en este caso, por la poesía medieval.

¡Drum! El tambor suena por tercera vez y muestra el cambio de perspectiva sobre la Guerra Civil. Al principio hubo optimismo hacia las hostilidades. Enfrentarse significó la mejor vía para resolver diferencias. Después, la realidad mostró caos y desesperanza, un infierno terrenal. En la recta final de la guerra, la incertidumbre reinó: algo debía ocurrir para alcanzar una solución. Whitman pensó en la reconciliación democrática tras leer la Comedia. Los hechos debían concluir de manera benéfica, no sólo para las regiones, sino para toda la nación. Versos y acciones se corresponden para pertenecer a la visión de lo ocurrido a nivel individual -de Whitman-y conjunta - de la nación entera-. 
La idea inicial apuntó a un triunfo rápido y contundente de las fuerzas norteñas. Cuando la guerra estalló, los jóvenes de ambas regiones se enlistaron. Su entusiasmo cegó cualquier duda sobre una victoria veloz. "Ni ellos, ni los políticos que los alentaban, dudaban que su causa - la preservación de la Unión o la independencia de la Confederacióntriunfaría en un par de meses.” (Pani, 2016, p. 133). La idea se desvaneció tras los enfrentamientos y las pérdidas. Ningún bando obtuvo una ventaja inmediata. Actos seguido, la guerra se prolongó hasta volverse una de las más largas en la historia de los Estados Unidos.

La primera sección del poemario arraigó el entusiasmo patriótico de los jóvenes e idealista por terminar pronto con la guerra. Whitman compartió la emoción de los voluntarios, como su hermano, por las hostilidades. Su apoyo, aunque nunca implícito, era innato hacia las tropas unionistas. Él había nacido en el Norte y había admirado a personajes como Abraham Lincoln. Sus versos claro que defendieron las posturas y términos nordistas. Además, exhibieron la vitalidad, la fuerza y valentía de sus soldados para combatir. Ellos serían los precursores, los pioneros de la renovación nacional al término del enfrentamiento.

Debemos marchar, mis queridos, debemos soportar la peor parte del peligro,

Nosotros, las razas jóvenes y nerviosas, todo depende de nosotros, ¡Pioneros! ¡Oh, pioneros!” (Whitman, 1865, versos 6-8). ${ }^{28}$

En la primera parte de Redoble, los daños de la guerra no existieron. Al contrario, Whitman la presentó como un deseo colectivo. Los poemas cantaban discursos a favor de la Unión. Las palabras dejaron el sentido metafórico y se convierten en mensajes literales de defensa y apoyo hacia el conflicto mismo. Incluso, no sostuvieron un diálogo con el lector,

28 “Pioneers! O Pioneers! 
tal y como en las primeras ediciones de Hojas de hierba. En Redoble, el poeta definió la guerra como un terreno donde las causas norteñas debían establecerse y florecer.

El poema que revisa el entusiasmo nacional por ir a la guerra es "Primero, oh, unos cantos como preludio" (Whitman, 1865). Desde el verso inicial, Whitman sustentó su postura y percepción optimista hacia los hechos y la Guerra Civil: Primero, oh, unos cantos como preludio / Que resuenen en el tenso timbal el orgullo y la alegría de mi ciudad" (versos 1-3). Después discutió su propio orgullo de pertenecer a un hecho en beneficio de la vida nacional: “como condujo a las demás a las armas, como dio señal, / cómo se incorporó, ágil sin vacilar un instante" (versos 3-4). La beligerancia había comenzado y el poeta se alegró porque su ciudad participaba y defendió las causas de la Unión.

El optimismo de los primeros versos también era incontrolable: “(¡Qué soberbia! ¡Oh Manhattan, mía, simpar! / Oh, la más fuerte en la hora de tribulación! ¡Oh más genuina que el acero!) (versos 5-6).” Si se busca un tono más explícito, y como sugiere Pearcy (2013), se debe cambiar la palabra Manhattan por Estados Unidos. Ahí, el verdadero significado del poema se torna más claro. El unionismo se respaldaba con la energía de sus jóvenes soldados, con el apoyo de sus habitantes. El bando Norte contenía la fuerza suficiente para imponer su voluntad durante la guerra.

La victoria era irremediable. Esa idea apareció constante en los versos de Whitman. La sección inicial del poemario alienta a los jóvenes a forjar una nación "No sólo por los intereses económicos o políticos, sino por el deseo de imponer la unidad nacional a partir de las causas de la Unión” (Abdullah, 2014, p. 4). La seguridad y el futuro del país, al igual que la de sus jóvenes, se darían al establecer una nación democrática, libertaria y unionista. La primera parte de Redoble se formó con base en poemas-proclamas más que en una visión negativa de las hostilidades. 
Uno nunca debe ceder, esa es la sustancia final, al pensamiento que todo es seguro,

Fuera de la política, triunfos, batallas, vida, ¿qué queda finalmente?

Cuando los espectáculos se rompen, ¿qué es lo seguro?

(Whitman, 1865, versos 4-6). ${ }^{29}$

La segunda parte del poemario se modificó con base en los terrores de la guerra. En esta misma investigación se han mostrado algunas de las complicaciones del enfrentamiento. La guerra se aletargó para asemejarse a un infierno terrenal. El desenlace de la guerra no llegó. El campo de batalla anuló el entusiasmo de la juventud combatiente. La realidad golpeó a unionistas y confederados. Los versos de Whitman coincidieron con el sentir nacional, así como con su actividad dentro de hospitales y enfermerías. Desde esos lugares, plasmó el costo, al igual que los estragos de las hostilidades.

La duración y alcances del conflicto golpearon a los gobiernos de cada región y a la población fuera del campo de batalla. La Guerra Civil no terminó en meses debido a distintas causas. A pesar de la superioridad demográfica e industrial norteña “-con sus 20.7 millones de habitantes contra los 3.5 del Sur, 20 mil millas de vía férrea y una fábrica de locomotoras contra 9 mil en el Sur-" (Pani, 2016, p. 133), la parte sureña resistió cada embate. Ambos bandos movilizaron a toda su sociedad. La guerra fue total y ocasionó mayores estragos, pérdidas, además de consecuencias.

Las decisiones políticas y económicas establecieron un juego de ajedrez para mermar a los oponentes. El Sur, por ejemplo, eliminó la lucha partidista y la publicidad de los debates del Congreso. Además, se le exigió a la población, granjeros y plantadores la décima parte de sus ganancias para obtener recursos para la guerra. El Norte, bajo el mando del presidente Lincoln, constituyó un mando militar moderno, con un general en jefe (Ulysses S. Grant)

\footnotetext{
${ }^{29}$ Véase el poema "Quicksand Years".
} 
para coordinar las campañas de la Unión. Además, el gobierno impuso impuestos para prácticamente todo y así sustentar los gastos del conflicto. Cada acción provocaba una respuesta del bando contrario. La conclusión se alejaba aún más.

Como consecuencia del letargo, la guerra adquirió más realidad. Whitman la plasmó también en sus versos. El entusiasmo de los primeros poemas y de la nación desapareció por completo. El poeta, que había celebrado un triunfo tempranero, cambió sus versos para dibujar un panorama general de derrota. Su percepción cambió no sólo por los hechos y las decisiones de ambas regiones, sino por lo visto tras la búsqueda de George. Aquello no sólo modificó su perspectiva, sino su manera de escribir.

Whitman reconstruyó el argumento de sus poemas a partir de su interacción con la guerra real, con los soldados heridos en el campo de batalla y su vida como enfermero. En la primera parte, su contacto había sido nulo con esos hombres. "El escribió lo que quiso porque no tuvo un punto de referencia" (Pearcy, 2013, p. 29). Su apoyo estuvo cegado por la lejanía del conflicto. Después de trabajar en hospitales y conocer a los participantes del conflicto, tuvo que cambiar sus versos y poesía.

El poema donde se guardó tal cambio fue "El curador de heridas". Whitman concibió su labor de enfermero y su visión sobre los horrores de la guerra. Plasmó experiencias y su contacto con soldados norteños y confederados. Desde los hospitales, entendió que ninguna causa podía soportar los daños ocasionados a la nación. Además, enfatizó los sacrificios de los soldados, el de la población, el del país; reconoció la labor de doctores y enfermeros por cuidar a los participantes de una guerra inútil.

Así pues, en silencio, en las proyecciones de los sueños, Vuelvo, prosigo, trenzo mi camino por los hospitales, Alivio lesionados y los heridos con manos balsámicas, Paso las noches junto a los que no pueden descansar, algunos muy jóvenes, 
Otros con grandes padecimientos: recuerdo una experiencia dulce y triste

(Los brazos afectuosos de muchos soldados han rodeado este cuello, y descansado en él;

Los besos de muchos soldados guardan estos labios y esta barba).

(Whitman, 1865, versos 59-65).

La tercera sección de Redoble de tambor plasma una postura reconciliadora ante los estragos de las hostilidades. Los versos en esta parte se cargaron de un espíritu y una voz renovada. En ellos, Whitman buscó la calma después de la tormenta, la reconciliación como única salida. El lado vencedor debía ser la nación por completo, no sólo un bando. Para lograr el objetivo, la camaradería se colocaría por encima de cualquier interés. El conflicto debía terminar de una vez por todas. Esta temática dirigió la tercera parte del poemario.

La voz del poeta fortaleció su rol social: "Whitman escribió con la firme creencia de que sus poemas podrían reconstruir a la nación con una nueva base democrática y social. El poeta debía ser el mediador" (Abdullah 2014, p. 10). Las arengas y los horrores se volvieron propuestas. Ese último cambio se sustentó en las experiencias plasmadas por el poeta tras curar a los heridos, en su historia individual y, por supuesto, en los mismos registros elaborados sobre la Guerra de Secesión. Las batallas no sólo dejaron destrucción, sino un espíritu de camaradería en los soldados. Whitman lo captó y comunicó en versos.

Cenizas de soldados del Sur o del Norte,

Mientras reflexiono, en retrospectiva, murmura un canto en el pensamiento,

La guerra se reanuda, una vez que entiendo sus formas, Los ejércitos avanzan de nuevo.

[...]

No me des descanso, hazme una fuente,

Para exhalar amor desde mí y a donde quiera que vaya la rocíe como húmedas perenne

Al igual que a las cenizas de todos los soldados muertos del Sur o del Norte (Whitman, 1865, versos 1-4 [... 39-41). ${ }^{30}$

\footnotetext{
${ }^{30}$ Poema "Ashes of Soldiers".
} 
Ésta última sección de Redoble de tambor tiene la fuerza necesaria para llamar a la reconciliación de todo un país. La guerra, a pesar de todos los desastres, mostraba una lección: derrumbarse para renacer y rehacer una nación completamente distinta a la del inicio del conflicto. El poeta hizo conciencia de los muertos. Él mismo los vio como tantos miles que participaron en la Guerra. Su poesía levantó una voz para reflexionar sobre esa experiencia colectiva, inocularla en otras generaciones, en otros jóvenes capaces de sustentar una nación renovada y reconstruida.

Mis muertos absorben al Sur o al Norte: los cuerpos de mis jóvenes absorben su preciosa sangre,

Eso me confía fielmente de que habrá muchos años más (Whitman, 1865, versos 11-12). ${ }^{31}$

Vida y letras del poeta detallan instantes adaptados a la evolución de la Guerra Civil. Ambas recogen el imaginario inicial de los implicados y sus posteriores cambios. Comienza con la idea de un triunfo rápido y eficaz de la Unión; el conflicto podía correr los riesgos y cobrar los costos necesarios. Esa actitud cambió para uno y para todos. La beligerancia enseñó lo impredecible, lo desigual y lo cruel de ella misma. Hubo una mudanza de posturas: no habría victoria veloz, los riesgos y costos formaban un infierno terrenal. La única solución podría darse con la conciliación de todo el país.

La postura de Whitman en su Redoble enfatizó una reconciliación y término de las hostilidades, así como una resurrección cimentada en el espíritu de unión. "Las instantáneas de eso poemas recogen visualmente el impacto, la inmediatez y la brutalidad de las escenas de guerra que encienden esos recuerdos.” (Martín, 2003, p. 102). Obra y poeta ofrecieron una lectura capaz de dar información sobre la postura cambiante respecto de la guerra: desde la

\footnotetext{
${ }^{31}$ Véase el poema "Pensive on Her Dead Gazing".
} 
valía de las causas y el orgullo por defenderlas, la verdad de los horrores y la obtención de un ideal de reconciliación.

Después de escuchar sólo tres redobles, la riqueza histórica de los poemas queda esbozada y pendiente. Los sonidos mostraron la adaptación de distintas realidades en los versos de Whitman. Tal vez, por esa razón, el poeta pensó que su libro y la Guerra Civil eran un mismo ente. Todo Redoble gira en torno al conflicto: dramas familiares, hospitales, enfermerías, soldados en un infierno terrenal, además del cambio de perspectiva. Sin embargo, la obra aún tiene información y sonidos por descubrir o escuchar.

El poemario posee versos y metáforas poderosas, aunque no la totalidad de la guerra. Más bien, contiene la culminación poética de Walt Whitman. Redoble de tambor cobra mejor sentido con esta frase. Ante los ojos de Whitman, la Guerra Civil logró para Estados Unidos lo que él había esperado que lograra su poesía: lograr un cambio a nivel nacional.

Acabó con los males sociales que su primera poesía había tratado de rectificar. Aclaró la atmósfera como una tormenta, una imagen que le gustaba usar para la guerra. Pareció librar al Norte, especialmente a Manhattan, de muchos de sus problemas anteriores a la guerra. Convirtió el tema difuso y cambiante de los derechos del estado en contra del poder nacional: Secesión contra Unión. Hizo que la mayoría de la gente en los estados del Norte se uniera en torno al ideal de unión que él había acariciado durante mucho tiempo. Reunió a prácticamente todos los estadounidenses. Norte y Sur, en una acción común y un espíritu de heroico sacrificio (Reynolds, 1995, pp. 413-414).

El país debía comenzar un proceso de reconstrucción con base en reformas constitucionales, rivalidades partidistas, así como distintas actividades políticas y sociales (Pani, 2016). A pesar del panorama de reorganización, los versos de Whitman también ocupaban ya un lugar en el imaginario estadounidense.

¡A ti vieja causa! [...]

Estos recitativos los dirijo hacia ti, -Mi libro y la guerra son uno, 
La fusión de los espíritus, yo y lo mío, mientras la contienda dependía de ti,

Tal y como gira una rueda sobre su eje, este libro se atestigua a sí mismo, Alrededor de la idea de ti (Whitman en Reynolds, 1995, p. 413).

Al unir sus objetivos personales y poéticos con la guerra, Whitman le atribuyó a su Redoble un tono sugerente. Su obra no sólo significó un volumen poético de la Guerra Civil; fue un volumen creado desde una perspectiva personal arraigada en experiencias individuales y comunes. Sus versos resguardan emociones, vivencias, redobles de un tambor, que no pueden ser reproducidos en otros libros o documentos sobre la guerra. Whitman se preocupó por capturar la guerra real, aunque esta ambición le llevó a capturar solo una visión parcial y muy pequeña de los hechos.

\section{Instantes de descripción, expresión y evocación de la Guerra Civil}

A pesar de ser una visión sobre algún acontecimiento, el trabajo del poeta también funciona como una fuente informativa del pasado. Para ello necesita ser criticado, complementado o refutado como contenedor de información. En contraste con sus limitantes, los poemas poseen fuerza distinta a la de otros documentos: los instantes poéticos. Con esa base, los versos pueden describir, expresar y evocar un hecho particular.

El instante poético es un tiempo ambivalente y necesariamente complejo. Para Gastón Bachelard (1999), esa medida forma parte de la longitud de un hecho. Es decir, la duración común -inicio y final- de alguna situación precisa. A la vez, conserva la capacidad de detener tal sucesión para capturar una imagen, una metáfora, un verso. Su doble valor no sucede en la progresión del tiempo "como un vulgar balance de alegrías y penas pasajeras" (p. 99). La dificultad del instante poético se ubica en el recorrido de dos trayectorias temporales pertenecientes a una sola realidad. 
El poeta utiliza las trayectorias del instante para escribir acerca de los hechos a su alrededor. El tiempo horizontal le ayuda a ordenar su realidad: es tan común como el agua que corre en el río. De manera simultánea, el tiempo vertical lo utiliza para separar un momento de la continuidad de los hechos. El escritor lo hace brotar, lo extrae y lo captura con base en sus palabras y lenguaje. De esa manera, la verticalidad resalta y rompe la horizontalidad, pero también le brinda atención a un momento en la historia.

El poeta hace brotar instantes, los pone en palabras y los dota de significado. A pesar de la complejidad, esto es una tarea a medias. Su trabajo no recae en romper la continuidad del tiempo, sino en reinsertar los instantes verticales en la continuidad de los sucesos. Con esto se logra que un momento sea considerado como una expresión social inseparable de otras manifestaciones históricas (Paz, 1972). Resaltar y separar los instantes, como planteó Bachelard, quedaría en una mera manipulación verbal. El poeta debe regresarlos para ayudar a la comprensión de un suceso.

Al reinsertarlos en el mundo, los instantes poéticos pueden incrementar lo sabido sobre algún hecho. Narran una manera de observar al mundo, pero a la vez, narrativizan la realidad de ese lugar. Es decir, manifiestan el hecho con pruebas -palabras-; respetan el orden cronológico de los sucesos; además muestran la causa y los efectos de los mismos (White, 1992). A pesar de poseer estas características, un instante poético no es un momento independiente, pues pertenece a la realidad de quien lo separa y lo escribe. El poeta utiliza su lenguaje para dotar a los instantes de un tejido lingüístico fechable.

Cada instante poético nunca podrá ser entendido por sí solo. Por supuesto que existen momentos logrados con simpleza: dirán sólo lo escrito ahí y no más. Una fruta puede ser una fruta. Una guerra sólo puede ser una guerra. No obstante, también existen momentos donde debe apreciarse el contexto social, cultural, o político. Con ello se puede entender la retórica, 
los sonidos o silencios. Un poema debe ser completado o contrastado con otras fuentes para enriquecer su pertenencia dónde y cuándo fue creado.

La lectura y comprensión de los instantes poéticos agrega significados a un poema, a su autor y a su contexto. Su lectura atenta puede conmover e informar. Además, pueden revelar el propio grado de "inversión emocional del poeta" (Walker, 2014, p. 87), nacido de sus propias actitudes, experiencias, o emociones sobre un hecho. La ambivalencia temporal de los instantes poéticos, así como su reinserción en el mundo, pueden enriquecer el conocimiento tanto literario como histórico de un momento en el pasado.

La poesía es una metafísica instantánea. En un breve poema, debe dar una visión del universo y el secreto de un alma, un ser y unos objetos, todo al mismo tiempo (Bachelard, 1999, p. 93).

Con la discusión anterior, busco argumentar que los poemas de Walt Whitman contienen instantes poéticos pertenecientes a la realidad de la Guerra Civil. Sus poemas revelan momentos no sólo llenos de valor literario, también contribuyen al recuerdo colectivo y consciente del pasado. Sus palabras se dotaron de sentidos históricos pues construyeron un producto social y perpetuaron la existencia de su sociedad (Paz, 1972). La poesía de Redoble forma parte del imaginario estadounidense al resguardar instantes poéticos llenos de propiedades sociales, culturales e históricas.

Las trayectorias de los instantes capturados por Walt Whitman pueden leerse como parte de los sucesos en la Guerra Civil. Su horizontalidad organizó acciones sucesivas: de un punto inicial a uno final. Mostró de manera ordenada su ánimo hacia el conflicto, su voluntariado en hospitales, además del cambio de perspectiva sobre las hostilidades. De manera simultánea, la trayectoria vertical de los instantes interrumpió la continuidad y le permitió profundizar en detalles sobre la guerra. Esa verticalidad sigue aún pendiente en el análisis de la obra del poeta. 
El estudio de la verticalidad de los instantes descansa en tres categorías: la descripción, la expresión y la evocación de un hecho. El primero, enuncia consciente la situación del mundo, no es más que la relación literal de las palabras con los acontecimientos. El segundo expresa la visión individual y conjunta del mundo, algo primordial para recrear y entender el pasado. El tercero actualiza las palabras y los significados para manifestar el pasado en el presente. Los poemas de Whitman pueden estudiarse con base en la verticalidad y las tres propiedades del instante.

Las descripciones cuentan algo, o como se dice comúnmente en inglés, toda History es una story. Se relata el momento, lo sucedido, en cierto lugar y tiempo. Los problemas parecen lejanos, a veces no se plantea ninguno. La función primordial de una descripción apunta a explicar más que a comprender un hecho. Las características descriptivas de los instantes sólo enriquecen el carácter narrativo de un suceso. Muchos de los poemas de Redoble contienen versos de este tipo sobre la Guerra Civil.

En el poema “La caballería cruzando un vado", Whitman (1865) capturó un momento simple y pintoresco: “Serpentea el escuadrón, en formación de batalla, entre islotes verdes. / Avanza sinuoso, y las armas refulgen al sol: escucha cómo resuenan los metales" (versos 12). No hay nada más que entender. Las palabras son precisas: el cruce de la caballería en el río y nada más. "Observa el río de plata: los caballos chapotean y se detienen a beber; / Observa a los jinetes de tez curtida, que descansan, con indolencia, en las sillas: cada grupo, cada individuo, es un cuadro" (versos 3-4). Los versos explican, hablan y colorean un momento.

Los instantes descriptivos golpean al lector directo y con fuerza. No se debe entender nada más que la literalidad de las palabras. Los poemas de Whitman de corto aliento -no muy largos- son los contenedores de imágenes rápidas y concretas. "Junto a la llama 
temblorosa de la fogata", cuenta la experiencia de un soldado mientras hacía la guardia nocturna. Sus compañeros duermen, los sonidos de la penumbra lo inquietan, mientras su mente viaja nostálgica al hogar, al pasado, al seno familiar que lo espera - tal vez- después de la guerra. Todo esto sucede, mientras el valiente hombre mira atento la flama temblorosa de la fogata:

Junto a la llama temblorosa de la fogata

Me rodea una procesión, lenta y solemne. Pero primero advierto

Las tiendas del ejército dormido, el contorno borroso de los campos y los bosques, La oscuridad rasgada, aquí y allá, por las fogatas, el silencio, Alguna figura que se mueve, cerca o más allá espectral, Los matorrales y los árboles (al levantar la vista, parecen mirarme furtivamente),

Mientras desfilan en procesión mis pensamientos, oh, amables, prodigiosos pensamientos

Sobre la vida y la muerte, sobre el hogar y el pasado y los seres queridos, y sobre los que están lejos.

Forman una solmene y lenta procesión, mientras, sentado en el suelo, Atiendo a la llama temblorosa de la fogata.

(Whitman, 2019, poema completo)

El poeta, muchas veces, atestigua un hecho que lo lleva a escribir o relatar. En un poema se reproduce la observación y la captura del instante. Las descripciones reproducen un momento hecho objeto. Una vez en los poemas, como documento, los instantes se vuelven observables. Su discurso permite una lectura simple y coherente sobre un suceso dispuesto a ser leído y comprendido de manera inmediata.

Las descripciones se componen de palabras o enunciados de una experiencia, visión o memoria. A su vez, están inmersos en una red semántica construida por el discurso del poeta. Cuando se describe, se refiere a algo allí: “a una situación del mundo [...] al discurso que los crea y el historiador [o poeta en este caso] que los enuncia.” (Bermejo, 2005, p. 7). El trabajo de Whitman capturó instantes con palabras entendibles, fáciles, para referirse al conflicto interno de los Estado Unidos. 
Adiós, soldado,

El de las rudas campañas (que hemos compartido),

Las marchas forzadas, la vida en el campamento,

La acalorada refriega en frentes opuestos, las largas maniobras,

Las batallas, rojas, y sus matanzas, el estímulo, el juego terrible y brutal

[...] (Whitman, 1865, versos 1-5) ${ }^{32}$

Ahora bien, los instantes de un poema trascienden el plano descriptivo cuando se escucha la expresión del pasado: tal y como un reflejo de las características de aquel tiempo. La historia, la poesía y sus instantes enuncian la visión del mundo y los valores, así como los sentimientos de quien los crea. Sin embargo, esa expresión no sólo es individual, también corresponde a una visión colectiva sobre un hecho. No es el mundo y las palabras del escritor, las de uno y a la de todos a la vez.

Expresar supera a la descripción. No sólo basta con contar una historia, sino saber ir más allá. Esto es incluso innato de los instantes en la poesía: “al fin y al cabo, en historia los seres humanos hablan acerca de otros seres humano, que podrán ser, con respecto a ello, próximos o remotos, pero siempre poseerán una naturaleza común.” (Bermejo, 2005, p. 17). Los poetas, como cualquier humano, se mueven por sus pasiones y necesidades. Su discurso, movido por estos elementos, también contiene ideas, prejuicios, valores estéticos de su época y realidad.

Walt Whitman expresó no solo su sentir, sino el de toda una nación ante la guerra. Este argumento se desarrolló en el apartado anterior. Al inicio, el poeta evidenció un sentimiento nacional y patriótico de apoyo a la beligerancia como solución ante la división estadounidense. Ese pensamiento sufrió modificaciones no sólo a nivel individual, sino colectivo. El poeta señaló su descontento, el cual coincidió con el de la población y los

\footnotetext{
${ }^{32}$ Véase el poema "Adieu to a Soldier"
} 
involucrados en la guerra. Los objetivos nacionales debían ser otros ante los estragos incontables e inconmensurables.

[...] Adiós querido camarada.

Has cumplido tu misión, pero yo, más belicoso,

Yo y esta combativa alma mía,

Empeñados aún en nuestra campaña,

Por caminos no hollados, en los que se apostan enemigos emboscados, y sufriendo dolorosas derrotas, numerosas crisis, a menudo confusos, Seguimos marchando, siempre adelante, seguimos haciendo la guerra; sí, aquí

Damos expresión a batallas aún más encarnizadas, aún más decisivas.

(Whitman, 2019, versos [...] 9-16)

Además de los estragos y el cambio de perspectiva, Whitman ideó una mejor conclusión para las hostilidades: una idea democrática. Bajo este estandarte, la nación podría resurgir de entre sus cenizas, o al menos llegar a un punto de comunión benéfica para todos. Esta idea no surgió desde un nivel individual. El sentimiento nacional apuntó a reforzar sus lazos, a terminar la guerra y abrazarse al espíritu de unidad.

Los cambios de ideas y de tono escritos en Redoble corresponden a la expresión individual y colectiva de la guerra. Los versos de conciliación mostraban una intención más humana, verosímil y cercana a los acontecimientos. El poeta recurrió a sus experiencias en los hospitales para mostrar la necesidad de alcanzar la unión nacional. La Guerra Civil no podía continuar como solución o respuesta de las diferencias, pues había desgastado tanto a la nación como a todos sus habitantes.

El poema que habla de este cambio de percepción se titula "Vuélvete, oh, Libertad". El texto sugiere el fin de la guerra y el camino de la nación hacia una nueva vida en común, benéfica, para el país. Incluso ese canto invita a dejar atrás los rencores del pasado, a renacer en una nación con metas futuras. Trascender el pasado auguraba mejores ambiciones, planes y sociedades, para una nación quebrantada desde su interior.

Vuélvete, oh, Libertad: la guerra se ha acabado; 
Apártate de ella y expándete sin vacilar, abarca, resulta, el mundo entero;

Vuélvete de los países que miran atrás y consignan pruebas del

$[\ldots]$ pasado,

Vuélvete, pues, y no te alarmes, oh, Libertad, vuelve el rostro inmortal

Al futuro, que es mayor que el pasado,

Y que se apresta, con premura y convencimiento, a recibirte.

(Whitman, 2019, versos 1-3 [...] 10-12).

Otro poema donde se expresa la idea de reconciliación, más allá de la democracia, sino con base en la simple reunión, es "A la tierra fecundada que pisaron” (Whitman, 2019). Este poema es uno de los textos finales de Redoble. Su ubicación no dista mucho de su intención pues contiene un instante expresivo sobre los estragos de la guerra. Al mismo tiempo, plantea la nueva dirección que los Estados Unidos debían tomar. Así Whitman, desde su individualidad, invoca su último canto para un objetivo en común.

Desde un principio, el poeta manifiesta el sentimiento de unión que debe prevalecer después de la guerra. El aire es fresco y hacia el horizonte se extiende un panorama restaurado de paz: "A los feraces campos emanantes y a los paisajes infinitos allende esos campos, al Sur y al Norte, / A la tienda fecundada de todo el mundo Occidental, para que dé testimonios de mis cantos / a las colinas de los Allegheny y al incasable Mississippi [...]" (versos 4-6). El poema comienza con un gran tono descriptivo: las letras de Whitman se dirigen a todas las regiones de la nación.

Sin embargo, en los versos siguientes, Whitman revoluciona sus palabras: convoca a las rocas, a las llanuras, a los héroes, al mar remoto o a los vientos invisibles. El poeta crece en intensidad y deja las descripciones a un lado para expresar la idea de reconciliación nacional. Ya las regiones no deben existir: "El hielo y la lluvia del Norte, que me dieron principio, me alimentan hasta el fin, / Pero mis cantos solo madurarán completamente con el 
ardiente sol del Sur." (versos 13-14). Al final, los individuos deben acercarse a la tierra, a su país y pensarse como un todo.

Expresar un instante guarda una forma de pensar y decir las cosas. No sólo desde un nivel individual, sino correspondiente a una comunidad. Cada presente, de donde se escribe o se lee, luce muy alejado de los tiempos pasados. Los instantes poéticos expresivos sobreviven aún fuera de esa realidad. Hablan de mundos dejados atrás en cualquier tiempo. No pueden contarse por sí mismos. La tarea del poeta fue escribirlos en su momento, enunciar su realidad individual y conjunta para expresarla a lectores futuros.

Ahora bien, aquí surge la tercera categoría de los instantes: la evocación. Las descripciones y expresiones son capaces de evocar un momento por más inexistente: me refiero a un momento en la historia en el pasado. No obstante, ese instante sigue perpetuo en los poemas. El acto de evocar es similar a actualizar la ausencia mediante signos físicos o indicios que manifiestan la existencia de un fenómeno que parece inobservable e incluso inentendible. Evocar es cultivar la memoria a través del quehacer histórico; es un acto de lectura donde se apela a rememorar y a recrear los instantes poéticos logrados por el trabajo del poeta.

Cultivar la memoria es un fenómeno circunstancial al funcionamiento de la mente humana y se halla asociado al mantenimiento de nuestra identidad: la construida a partir de la relación con los restantes miembros de nuestra familia o el resto de la realidad social o cultural. El poeta, en este caso en específico, evoca los instantes de su propio tiempo, la forma de hablar, de comportarse y de ver el mundo, así como relacionarse con otras personas y con él mismo.

Walt Whitman no fue la excepción. Me atrevería a decir que cada verso de Redoble de tambor evoca distintos momentos descriptivos y expresivos tanto de su existencia, como 
de su historia personal, así como los de la historia nacional. En el primer capítulo de la investigación, los versos utilizados materializaron la infancia, la formación, así como diversas etapas definitorias para Whitman. En este segundo capítulo, la guerra fue descrita y expresada en varios versos. El análisis de su obra permite entender el desempeño y el actuar del poeta en su realidad.

La evocación encontrada en el trabajo de Whitman se acotó a diversos instantes de la guerra. Expresó y describió instantes vistos, vividos y entendidos por él mismo. Al tomar esos instantes y volverlos poemas, uno como lector e interesado en las letras del poeta puede recrear esas experiencias plasmadas. Con esto intento decir que la evocación resulta casi innata en cada poema o verso. Con la lectura de un poema se hace memoria de un momento que se ha ido, pero que puede volver.

Yo no sólo veo y oigo trozos de tela:

Yo oigo la marcha de los ejércitos, oigo al centinela vigilante, Oigo los gritos de júbilo de millones de hombres, ¡oigo la Libertad!, Oigo batir los tambores y sonar las trompetas, Yo mismo parto, me elevo con rapidez y vuelo [...] (Whitman, 1865, versos, 61-65) ${ }^{33}$

El poeta evoca instantes para mantener vivo el recuerdo de una persona, hecho $\mathrm{u}$ anécdota. La memoria es selectiva y por lo tanto la evocativa. No se puede traer ni recordar todo; se reconfigura de una forma u otra en función de las circunstancias personales o colectivas de cada momento. A través de su lenguaje, de su ficción verbal, el poeta crea un discurso perteneciente al presente y al pasado que "irá acompañado por diferentes tipos de explicaciones y, en el seno de ese relato, habrá una determinada construcción del tiempo.” (Bermejo, 2005, p. 17). El poeta utiliza instantes evocativos, no para transmitir un recuerdo, sino como contendor de acontecimientos en su propio mundo.

\footnotetext{
${ }^{33}$ Léase el poema "Song of the Banner at the Daybreak"
} 
Los momentos capturados en muchos productos poéticos, informan, documentan y relatan la visión de un autor sobre una realidad experimentada. O como Iván Portela (2008) mencionó al respecto: "Si un poema hace reír o llorar, no es motivado por la cursilería, sino que ha de haber un fenómeno intrínseco que hila la reflexión del lector con el instante en el que fue elaborado el poema." (p.78) Los documentos de la poesía así sus creadores pueden considerarse como informantes estéticos que van más allá de la interioridad y subjetividad individual. Al leerla, la poesía permite al lector asirse de ella y hacerse con ella. La lectura y comprensión de la poesía la faculta como una herramienta más del pasado.

Con base en las tres características de un instante poético, se puede acercar a otra perspectiva de la historia. La poesía contiene un tipo de lenguaje, creación e incluso vocabulario, pero no deja de aportar conocimiento sobre momentos pasados. Su valor documental recae en saber qué leer y entender cómo habla el poeta, en mirar las descripciones, expresiones y evocaciones. La lectura de una obra literaria, como un poema, implica entender subtextos y contextos para encontrar información. Los poemas no omiten su valor y contención de datos debido a los instantes poéticos que resguardan.

Los instantes descriptivos se realiza con base en una red semántica. El poeta escribe palabras. Además de sólo decir, ellos pueden expresar el mundo de su autor, sea o no de manera intencional. Creador y creación vuelca en palabras la percepción de una realidad, de una existencia y en muchos casos, de un hecho concreto. Esas palabras que describen y expresan, evocan los momentos consagrados. Como una epifanía, se liberan cuando el mismo poeta las nombra y un lector las mira. La evocación revive descripciones y expresiones de una percepción del mundo. La relación entre los instantes poéticos brinda así un testimonio cristalizado, además de tangible sobre el pasado. 


\section{Capítulo III}

\section{La poesía en la historia: utilidad y límites}

\begin{abstract}
Por la boca del poeta habla -subrayo: habla, no escribe- la otra voz. Es la voz del poeta trágico y del bufón. La de la solitaria melancolía y la de la fiesta, es la risotada y el suspiro, la del abrazo de los amantes y la de Hamlet ante el cráneo, la voz del silencio y la del tumulto, loca sabiduría y cuerda locura, susurro de confidencia en la alcoba y oleaje de multitud en la plaza. Oír esa voz es oír al tiempo mismo, el tiempo que pasa y que, no obstante, regresa vuelto unas cuantas sílabas cristalinas.
\end{abstract}

Octavio Paz

Pero la poesía es el impulso creador que habita en la palabra, siempre a punto de revelarse, de despertar, de convertirse en conocimiento y en trascendencia de sentidos, pasiones y verdades.

Patricia Villegas

Poems like these suggest the value of combining literary and historical approaches to enrich an understanding of the scenarios represented.

Greg Walker

Las dos primeras secciones guardan diferencias claras y al mismo tiempo arrojan la temática del tercer apartado. Después de mostrar la vida y la relación entre el poeta, su obra y la realidad, queda pendiente una discusión: las oportunidades de la poesía en el dominio de la historia. El tercer capítulo retoma el vínculo entre la poesía y una relación inquebrantable. Con ello se busca demostrar cómo y hasta dónde, tal unión puede aportar a una investigación histórica. Así surge el objetivo de ese apartado: evidenciar la utilidad y los límites de lo poético en el pasado.

Para desarrollar lo planteado deben retomarse dos argumentos inmersos en los capítulos anteriores. El primero resalta la relación de la poesía con un vínculo inquebrantable: poeta-poema-realidad. El segundo demuestra cómo y hasta dónde, tal unión puede aportar a una investigación histórica. De esta manera, el tercer capítulo difiere de sus antecesores en acento y estructura. Este apartado se origina desde la reflexión de lo escrito e investigado. Mis palabras buscan ser un aportar en la comprensión del pasado. 
Como un primer paso, la poesía debe asirse de una figura humana, de un guardián y un contenedor de realidad: el poeta. Cuando el escritor dialoga con ella para después plasmarla en un texto, sucede un efecto de liberación y expresión. Él la pronuncia a través de un cúmulo de palabras. Ella le responde. Ambos se enlazan en una relación recíproca, donde ninguno existe sin el otro. De esta manera, el poeta hace posible que la poesía se exprese y habite en una realidad específica. En el poema puede ser entendida, además de alojada en el pasado.

Atada del poeta, sus palabras y un texto, la poesía se suma a la historia. Greg Walker (2014) acertó al decir que "La crítica histórica agrega riqueza a nuestra comprensión de los contextos de un poema, pero esos contextos crean nuevos significados en el poema [...].” (p. 87). Tales obras conmueven a los lectores, aunque también los informan. Así, la poesía revela la inversión emocional del poeta, nacida de sus propios sentimientos y realidades. Cuando se relaciona con la historia, ambas trabajan en una compleja correspondencia de existencias, lenguaje, palabras, individuos o sociedades.

Por lo anterior, la historia puede considerar al resultado de esa relación irrompible como un testimonio capaz de otorgar conocimiento sobre otros tiempos. El poeta contiene la esencia de la poesía, crea un documento y lo brinda al legado histórico. El escritor de versos confía en sus palabras: originadas en su propio tiempo y parte de su realidad. A través del poeta, su lenguaje y obra, la poesía ayuda a reinterpretar historias individuales o colectivas con mayor profundidad.

Si lo poético ayuda a recrear un hecho, entonces también debe criticarse la información contenida. Ahí radica la tarea del historiador: en reunir para cuestionar los testimonios brindados por la poesía. El conocimiento del pasado se adquiere al responder preguntas. Los historiadores deben suponer que las evidencias son adecuadas $y$ 
enriquecedoras para su investigación. No obstante, la tarea no es sólo reunir, sino preguntarles para revelar su importancia: una fuente afirma las sugerencias de una duda. No importa su forma, sino la función de limpiar la incertidumbre sobre un hecho estudiado.

De esa manera, la historia surge desde la interpretación de las fuentes informativas. La poesía vinculada al poeta-poema-realidad queda plasmada en un documento existente con un contexto específico. Al ser pensado de esta manera, el historiador también puede cuestionarlo para obtener respuestas sobre algún suceso. Por estas razones, la poesía no se despoja de su capacidad reveladora de tiempos anteriores.

Esta sección se diferencia de las primeras pues no comienza con una discusión sobre la problemática. Aquí mi voz busca dialogar de manera directa con el tema. Este capítulo tampoco contiene un estado de la cuestión donde varios autores lideran la argumentación. Aquí trataré que algunos argumentos y mi voz vayan de la mano, como un acto de reflexión. Mientras la discusión sucede, busco volverme parte de la problemática, no sólo un complemento.

\section{Poeta-poema-realidad}

La poesía aporta información histórica, siempre y cuando se sostenga del poeta, el poema y la realidad. Esos elementos deben vincularse entre sí de una forma inquebrantable. Primero, el escritor necesita dialogar con la poesía para después crear un documento con base en un tiempo-espacio en específico. Al habilitarse del contexto del autor, la poesía logra facultarse de propiedades culturales, sociales y lingüísticas para brindar un vestigio individual y colectivo de la realidad: un poema.

El vínculo se origina desde la indefinición: la poesía se significa en sí misma y nada más. Quienes han discutido con y sobre ella, han brindado una sensación de conocerla. Sus 
palabras referencian y enlistan una infinidad de sustantivos que sólo funcionan como sinónimos: música, imagen, creación, expresión, silencio, lenguaje y un largo etcétera. Tratar de encerrarla en otra palabra suele ser una tarea riesgosa pues se cae en los dominios de lo ambiguo. No existe algún significado similar o un sinónimo correcto.

Martin Heidegger (1973), por ejemplo, identificó esa problemática y buscó hacer algo distinto. Además de haber creado una obra donde el ser y el tiempo son protagonistas, el pensador también se acercó a los dominios de la poesía -a la de Hölderlin en específicocon base en algo llamado la esencia esencial: "[...] un juego de palabras sin lo serio de la acción.” (p. 108). Si no se le pueden añadir similitudes o redefiniciones, entonces debe ser entendida a través de sus virtudes y formas de enunciarla.

Además, el filósofo enlistó no una, sino cinco posibilidades fundamentales para la poesía: 1) ser la acción más inocente de todas; 2) el hombre con base en su lenguaje testimonia lo que ella es; 3) así abre el diálogo entre hombres y dioses; 4) los poetas permanecen con-en lo que fundan; 5) el hombre habita este mundo de manera poética. Con estas máximas, Heidegger no intentó encontrar un concepto similar. Al contrario, en cada una de ellas, ató la poesía a una forma humana capaz de enunciarla, a la del poeta.

A la visión de la esencia, se unen los argumentos de María Zambrano (1996): la poesía puede ser catalogada como la sal de la tierra. Sin embargo, este bello y fértil concepto también queda en el aire si no se aterriza en el campo de la existencia humana. Para la pensadora española, la indefinición se deja a un lado cuando logra ser transmitida a través de las palabras del poeta. Así es como este personaje comienza a asentarse en la discusión, pues él aterriza lo intangible, los objetivos, el lenguaje, además de lo esencial de la propia poesía.

Cualquier ser humano puede dialogar con ella, pero no todos pueden obtener las recompensas del poeta. Según Zambrano (1996), la poesía no sucede a través de los filósofos, 
pues se dedican, durante toda su vida, a preparar su muerte. El poeta, en cambio, es su amante e hijo. Ella lo cría y él la necesita sin remedio. A pesar de la dependencia, cuando al escritor le llegue la muerte irremediable, ella podrá sobrevivir hasta encontrar a alguien más, a alguien con la capacidad de entenderla y nombrarla. El poeta es elegido por su capacidad de significar y asegurar la supervivencia de la poesía.

Al ser el seleccionado para dialogar y corresponderse, el primer paso del escritor es experimentarla en su realidad. Después volverla una expresión entendible. Una vez convertida en palabras comunes, "la poesía es posibilidad de encuentro entre el género y la idea ya que es allí donde se manifiesta el pensamiento" (Álvarez, 2013, p. 227). Es decir: cuando el poeta platica con la indefinición, entonces la poesía comienza a revelar sus secretos y posibilidades desde quien le habla.

Ahí radica la valía del poeta pues no se afana, ni se conforma de las cosas ya existentes. Al contrario, “La cosa del poeta no es jamás la cosa conceptual del pensamiento, sino la cosa complejísima y real, la cosa fantasmagórica y soñada, la inventada, la que hubo y la que no habrá jamás." (Zambrano, 1996, p. 22). Es un tipo soñador, inventivo y compartido de lo indefinible. A partir de su diálogo con la poesía, el escritor busca significarla, realizarla, además de expresarla, dentro de su propia realidad.

La manera de lograr tal realización sucede por medio de una imitación mutua. El poeta busca copiar, con sus propios recursos, la conciencia absoluta de la poesía. Ahí sucede un efecto de experimentación pues sólo reproduce los grandes movimientos de creación y de destrucción que se advierten en el mundo de lo poético. Pero al mismo tiempo, la poesía imita las formas humanas y representativas del lenguaje. Desde una línea de pensamiento aristotélica, copia las acciones humanas para reinterpretarlas - a veces tal y como suceden en la vida real, o a veces mejor o de peor manera-. 
Poesía y poeta no sólo basan su relación en la imitación sino en la comunicación entre dos mundos. Unida de esa capacidad lingüística, la poesía otorga una multitud de significaciones sobre una cosa. Gracias a esa relación, la humanidad ha podido conocer un poco del más allá, de otras realidades. "La poesía revela este mundo; crea otro.” (Paz, 1972, p. 13). A través del diálogo -de la búsqueda por significarse e imitarse-, la poesía comienza a adaptarse en culturas, sociedades e individuos. Ante la dificultad de redefinición, diálogo e imitación, una mejor opción es expresarla.

De esa manera, el poeta utiliza su lenguaje y sus palabras para vincular su mundo con lo discutido con la poesía. Para conocer la observación del infinito, el escritor se enfrenta a lo desconocido para después nombrarlo y reconocerlo. Lo consolida con base en sus propios recursos lingüísticos, para después expresarlo en su realidad: la música, el lenguaje, las palabras, las imágenes y el silencio de lo infinito. Ahí descansa el primer vínculo de lo inquebrantable: poesía-poeta.

Cuando nace un verdadero poeta, puede expresarse mediante el lenguaje de la tribu, o bien crear para su uso exclusivo un verbo infinitamente trabajado, pero siempre será un poeta, que trabaja para la obra común [un poema] que no pertenece sólo a los poetas sino a los hombres (Béguin, 1986, p. 175).

No sólo su presencia, el lenguaje del poeta debe unirse a la conversación. Primero dialoga con la esencia de la poesía, para después expresar el resultado de tal comunicación. La capacidad lingüística forma parte de un método exclusivamente humano de transmitir ideas, emociones y deseos por medio de un sistema de símbolos. El del poeta tiene una característica más: concebir realidades conocidas o desconocidas, pero lo más importante para esta investigación: establecer límites humanos para la poesía.

Es así que el poeta asienta, modifica y adapta a la poesía en su discurso. Michel Foucault (1968) pensaba al discurso como el análisis espontáneo de la representación. Esta 
interpretación coloca a la lengua como la condición o motivo del hombre por percibir y mutar. El poeta acepta la labor y tiene una tarea más: representar las posibilidades de la poesía en el mundo humano. Ambos comienzan a crear lazos. Su lenguaje designa, articula y forja un lugar donde ella puede florecer: el poema es el sitio idóneo.

A través de su lenguaje, el poeta encarna a la poesía para dotarla de consciencia, servicio y límites espaciales, temporales y documentales. Ahí se conciben simbólicamente las visiones de algo infinito, además de las necesidades culturales, lingüísticas y perceptivas de cada poeta. Ese documento cambia y se apropia de condiciones humanas para desarrollar una potencia creadora-contenedora de conocimiento. De esta manera, la tercia poesía-poetapoema se materializa para obtener una oportunidad de suceder y aportar información al estudio histórico.

Un poema necesita de actualizaciones constantes. Ahí se expresan, dan sentido y comunican la interpretación del poeta sobre su realidad. Por esa razón existen tantos escritores, tantas obras. No es lo mismo referirse a la épica homérica o la comedia dantesca o al realismo de Whitman. Esos autores carecen de relación entre sí, porque cada momento creativo resulta ajeno del otro. ${ }^{34}$ Cada poema forma parte de los emblemas morales en lenguajes y momentos distintos. El texto debe actualizarse con base en las actividades humanas, así como en diferentes realidades espacio-temporales.

A través de esos textos, mucho antes que cualquier otro tipo de fuente documental, la humanidad ha podido acercarse a hechos o a situaciones sociales relacionadas con

\footnotetext{
${ }^{34}$ Esto no quiere decir que las influencias se hagan a un lado. Los poetas deben leer a otros poetas para entender esa visión y comunión entre lo ensoñado y el lenguaje humano. Lo que yo defiendo es que la Ilíada, o la Divina Comedia u Hojas de hierba no hablan de la misma persona, ni del contexto cuando fueron realizadas estas obras. Si bien, las metáforas sirvieron como modelos a seguir, esto no significa que representen el mismo escenario ni necesidades lingüísticas, sociales y culturales.
} 
acontecimientos de un mundo anterior. Desde la epopeya de Gilgamesh hasta en los poemas escritos en el siglo XXI, el trabajo de los poetas actualiza la visión del mundo. Sin su presencia, ni las simbolizaciones de distintas épocas, la humanidad habría sucumbido a una realidad inmutable y perenne. Por esa razón, el poema también parece un símbolo y expresión de cambio.

El poema media la experiencia del infinito poético y un conjunto de lazos comprensibles entre los hombres. Cada texto de esa naturaleza pluraliza los significados de la poesía en distintas realidades. Al mismo tiempo, revela y descubre las pasiones, intelecciones, virtudes, deseos o anhelos del poeta. Un poema depende de la existencia y del servicio de ese individuo. Ahí se guardan los emblemas indicadores y reconocibles de la actividad humana, pero también se comunican testimonios sobre algún suceso.

Al poema no le basta con simbolizar, también compartir la obra moral del poeta. Lo moral no debe encasillarse en el debate entre lo bueno y lo malo; sino en el comportamiento y las actividades de los individuos. No hay nada más histórico que las acciones y actividades del hombre en tiempos y espacios específicos. El poema resume el diálogo del poeta con la poesía para significarla humanamente y así poder asimilarla. Un poema no lanza juicios sobre códigos o comportamientos, más bien muestra y lidia con las percepciones y las propuestas de cada realidad.

Esta creación necesita de la virtud y capacidad del poeta. En el poema pueden leerse sentimientos interiorizados, pensamientos o acciones de una sola persona. Pero esa producción también simboliza comportamientos en común. El poeta forma parte de una sociedad y aunque perezca escribir en soledad, él comparte una realidad conjunta. Él injuria a la poesía - al estilo de Rimbaud- con su lenguaje y vuelca el resultado en una obra 
simbólica y común. Escribe para ser leído. Un poema guarda la consciencia del poeta y la pone al servicio de una comunidad espacial-temporal precisa.

Con tales exigencias, el poeta testimonia su realidad individual y colectiva: “[...] nuestros recuerdos son colectivos, son propios y de quienes los recuerdan a pesar de que se trata de hechos en los que hemos estado implicados nosotros solos [...]." (Halbwachs, 2004, p. 26). Al ser testigo de su tiempo-espacio, el poeta recrea su realidad a través de la palabra. A pesar de su individualidad, él pertenece a una colectividad. Su obra interpreta de manera conjunta la visión de un entorno. Por esa razón, el escritor toma su realidad y sustenta la acción poética en palabras significativas para sí mismo y para su sociedad.

El poema no sólo refiere símbolos comunicativos, también posee una naturaleza propia. De acuerdo con Jean Cohen (1982), éste relaciona de manera aditiva una serie de unidades aisladas, pero al mismo tiempo plantea sus propias necesidades. A pesar de conjuntar la esencia de la poesía a través del lenguaje del poeta, el poema no sólo posee un origen textual, no sólo es un papel lleno de símbolos comunicantes. También goza de características propias: refleja la condición humana del cambio y sustenta una potente fuente de conocimiento.

Un poema refleja la condición humana de cambio. Al concentrarse en la realidad del hombre, ese documento refleja instantes de consciencia y servicio entre el mundo poético y el del autor. Es un medio material único e irrepetible donde cada escritor adapta sus realidades y diálogos con la poesía. Cada poema cambia de instantes y momentos dondecuando fue creado. La condición humana del poema se refiere a la propiedad de modificar y adaptar sus significados a distintos entornos y contextos.

La condición cambiante simboliza y comunica lo más esperanzador o el más fatalista actuar del poeta. El poema debe ser pensado como un contenedor de instantes cargados de 
lenguaje humano. Los instantes son distintos porque abundan, son incontables. En el poema aparecen estos momentos llenos de lucidez o llenos de inestabilidad, pasiones, fanatismos, o un largo etcétera. Gracias a las condiciones humanas, en especial al cambio, ese texto testimonia la adaptación del poeta ante su entorno, comportamiento y actitudes.

Cada poema es un objeto único, creado por una 'técnica' que muere en el momento mismo de la creación [a esto me refiero con la idea de cambio y de condición humana]. La llamada 'técnica poética' no es transmisible, porque no está hecha de recetas sino de invenciones que sólo sirven a su creador (Paz, 1972, p. 17).

Al cambiar, el poema adquiere una potencia para contactar e impactar al mundo: “el poema es una metáfora donde los objetos hablan y las palabras dejan de ser ideas para convertirse en objetos sensibles" (Paz, 2008, p. 18). Lo anterior me parece incompleto: un poema también debe buscar más allá de significados sensibles o condiciones humanas. Éste debe otorgar un valor significante de esos elementos cambiantes; un valor creador y poseedor de conocimiento sobre el pasado.

Así entonces, el poema necesita adquirir potencia histórica. La potencia de este documento no se ubica en una línea recta evolutiva, sino entre el tiempo de la poesía: el enigma, el lenguaje, el hombre y el signo. En otras palabras, en la realidad. El poema es la llave de la poesía para aferrarse al lenguaje del poeta, a los símbolos plasmados en un texto. Como tal puede mostrar otro tipo de observación o creación humana, pero también testimoniar hechos precisos. Al plantear sus virtudes, el siguiente paso es encontrar cómo se ha utilizado y de qué otra manera sirve para la historia.

\section{La utilidad del vínculo inquebrantable}

La poesía y su infinidad de características deben atarse al poeta. A su vez, el escritor crea un poema, un documento donde logra transmitir la esencia y las posibilidades de lo poético en 
la realidad. Sin ese texto no habría versos que decir, o canciones que cantar, o plegarias que elevar al cielo. El poema resulta del vínculo inquebrantable entre la poesía, el poeta y la realidad. A través de versos, estrofas, metáforas, ritmo y lenguaje, se puede capturar y nombrar un hecho, un momento. "Un poema es una obra”, escribió Paz (1972, p. 14); aunque dicho de mejor manera, es una obra de arte donde caben las posibilidades humanas e históricas de la poesía.

Antes de argumentar y considerar a la poesía como una obra de arte, es necesario preparar el terreno. Pocos han podido utilizarla como una fuente de información sin caer en debates metafísicos u ontológicos. Cuando los versos resaltan en una investigación, a veces resultan anecdóticos o muchas otras parecen sólo ilustraciones. Por esa razón, este apartado busca discutir cómo ha sido utilizada en el estudio del pasado, para después encontrar una propuesta distinta, en la categoría de obra de arte.

Quien ha observado el valor de la poesía en la historia es José Carlos Bermejo Barrera (2005); incluso, resaltó las similitudes disciplinarias. En su ensayo intitulado Sobre la Historia considerada como poesía, mostró una relación y una función intrínseca compartida por ambas: crear momentos descriptivos, evocativos y expresivos sobre un acontecimiento. Esa tercia puede originar y formar parte de un discurso tanto histórico como poético. La historia y la poesía parecen se asemejan pues proyectan al mundo desde su ilusión e interés por actualizar la ausencia - la del pasado-.

Ambas disciplinas pueden ofrecer una visión de lo sucedido porque comparten tres propiedades del lenguaje de manera complementaria y no excluyente: descripción, evocación o expresión. Las tres suceden en pro de la recreación de un hecho. En distintos niveles de intensidad, pero suceden. De esa manera, prescindir o privilegiar excesivamente a una de las 
tres, ocasionaría que tanto la historia como la poesía perdieran su naturaleza específica: transmitir conocimiento histórico.

La conclusión de Bermejo es clara: con base en estas tres características del lenguaje, la poesía se parece a la labor histórica. Ambas contienen capacidad creadora sobre un hecho. Al mismo tiempo, no dejan de aportar conocimiento sobre momentos pasados. Su valor recae en saber qué y cómo mirar las descripciones, expresiones y evocaciones de una obra literaria como un poema. Me atrevo a completar esta idea: leer las tres propiedades del lenguaje implica entender y poseer conocimientos de subtextos y contextos capaces de conmover e informar. Una primera idea se forma, la poesía puede utilizarse debido a las propiedades lingüísticas-históricas que resguarda.

Como se elaboró en el apartado anterior, el lenguaje es algo humano. Facundo Ruiz (2017) indagó sobre la relación entre texto-autor y literatura-mundo. En su artículo "Poesía, historia y justicia en América Latina", negó la pertenencia de todos los escritos, libros y poemas en una corriente literaria de tipo mundial. La convivencia de relaciones teóricas, geográficas y políticas en un texto no pueden ser homogéneas. Todo no puede responder a las mismas características. Si todos los poemas, ensayos o libros correspondieran a un mismo estilo, a un mismo universo, se omitirían las particularidades de cada escrito. Esto provocaría una estandarización de los temas y las discusiones.

Ruiz se opuso a esta idea de generalización. Su argumento refiere la existencia de una relación de retorno entre el poema y el poeta. El papel del escritor de versos es realizar, desde su pertenencia histórica, una evidencia de su razón creativa. Esta evidencia otorga una pertenencia histórica, una memoria, a su autor. Poema y poeta son un espejo reflejados entre sí. Ambos pueden crear un fractal de posibilidades y razones en respuesta a su historicidad. Es una relación inquebrantable que vincula al mundo, al lector y al texto. 
Distinguir a la poesía como acontecimiento geográfico sirve para ubicar a los autores y a sus creaciones. Para Ruiz importa quién habla y dónde se lleva a cabo esta acción. A lo largo del texto, el autor defiende las propiedades de la poesía en América Latina. No se puede entender este territorio sin saber el lugar donde vive la palabra y los poetas que la habitan. Saber de dónde viene un escrito evita la homogeneidad propuesta por la literatura de tipo mundial. Con esto, puede pensarse que un acto poético debe pertenecer a un tiempo y un espacio determinados por el poeta.

Para la historia, lo expresado en un poema le permite observar un personaje, su lenguaje además de una realidad específica. En primer lugar, que un texto pertenezca y tenga un dominio y un contexto lo vuelve histórico: es una obra de arte hecha en un cierto tiempo y espacio. Saber cuándo, dónde y quién lo creo ayuda a la historia a descubrir lo más pronto, lo que está más a la mano. Un poema corresponde a tal edad, a tal época y lo escribió tal sujeto. Lo histórico brinca ante un simple vistazo.

Jorge Silva Castillo (2000), por ejemplo, puso la muestra de pensar a la poesía como un instrumento con cierta utilidad para la disciplina histórica. En Gilgamesh o La angustia por la mиerte, tradujo el que es considerado como el primer poema conocido por la humanidad. Sin embargo, en el prólogo de esa publicación existen dos puntos a retomar: la poesía es la fuente originaria de conocimiento y es la encarnación de un prototipo social.

Lo originalidad radica cómo decir las cosas. Antes de las fuentes documentales como primicia para la historia, dos tipos de testimonios dominaban la hechura del pasado: la oralidad y la poesía. Esta última era el instrumento en donde los hechos podían quedar plasmados con una idea central, estructurada y detallada de los hechos. Para confirmar este argumento, hay que echar un vistazo a la primera epopeya de la humanidad. Escrita en verso, Gilgamesh ha aportado a todas las leyendas o mitos de diversas culturas: varios fragmentos 
del poema han sido adaptados para explicar el génesis o la cosmogonía de civilizaciones o religiones.

El segundo argumento del historiador pondera el papel del poema como la encarnación de un prototipo social. Esto va más allá de quién o quiénes escribieron el poema. El autor es relevante cuando expresa su individualidad en un tiempo y lugar precisos. El poeta no representa la experiencia de un individuo, sino la imagen, la proyección que una sociedad logra de sí misma. Babilonia pudo ser conocida y reconocida a través de lo plasmado en unas cuantas tablillas. El autor del poema épico es desconocido, pero la civilización pudo mantenerse en el imaginario de la humanidad.

Con base en lo anterior, la función de la poesía en una sociedad ayuda a derrumbar mitos o percepciones del pasado. Susan L. Einbinder (2002), en Beautiful Death: Jewish Poetry and Martyrdom in Medieval France, utiliza a la poesía para conocer el martirio de las comunidades judías en Francia durante las Cruzadas. Además de las crónicas, la escritora se decanta por la poesía pues es un puente entre la memoria y los actos. Los versos pueden representar simbolización y estilización, pero también un material reconstructor de histórico y cultural de una colectividad.

La autora utiliza a la poesía como una fuente descriptiva del sufrimiento y la degradación de la gente judía. Pero también los versos ayudan a tener una visión sobre el cómo querían ser recordados: como mártires. Los tipos de mártires también son mencionados, desde los perseguidos hasta los obligados a escoger entre apostasía o muerte. Así Einbinder forja a las creaciones poéticas no sólo como símbolos en papel, ellas muestran al lenguaje como la pureza de un hecho y un testimonio.

La opresión hacia esta sociedad también se puede conocer a través de los versos. Para la escritora fue útil acercarse a los lamentos de los mártires para poder entender y compartir 
la persecución a esta sociedad religiosa al Norte de Francia: cuando un grupo de judíos decidió inmolarse en medio de este lugar en pro de su creencia religiosa. Además del hecho en sí, los versos arrojan una descripción de la postura y de la identidad judía en la Francia Medieval.

Otro punto relevante surge del uso de la poesía: la identidad. Un trabajo sobre esta temática fue escrito en México. Gloria Vergara (2005), en su artículo "Miradas que se cruzan: construcción de la identidad en las poetas mexicanas del siglo XX”, no sólo analizó la obra de algunas poetas mexicanas del siglo XX. El documento también sugiere el cómo la poesía de algunas poetas ha forjado y fomentado una idea sobre la identidad femenina en México.

En el ensayo se desarrollan dos premisas. La primera habla de la importancia de ser mujer y poeta en el siglo XX en México. La segunda, desde el punto de vista histórico, responde la idea anterior: ser poeta/mujer ha sido buscar reconocimiento y valor dentro de la idea nacional. Las ideas de la autora se corresponden de tal manera que llegan a una conclusión clara: ser poeta en México es luchar por obtener reconocimiento. Si no llega, entonces hay que buscarlo por medio de los versos.

Ahondar en la poesía femenina resulta una posibilidad de hacer comunión con el entorno y con la idea de nación. Las poetas y sus creaciones han estado insertas en la construcción de un género que forma parte de la crítica social y de la cultura en México. Vergara se apoya en las vidas de las escritoras, en los poemas y en otros documentos capaces de contextualizar la presencia de estas mujeres. Las poetas también fueron reveladoras del quehacer poético, fueron libertadoras de un mundo dominado por los escritores hombres y crearon así su propia esencia en la idea nacional y literaria mexicana.

Los trabajos discutidos utilizaron a los versos y a los poemas como herramientas principales de sus argumentos. El contenido sobre lo pasado no es ajeno para ningún autor, 
pero ninguno profundiza en este tema. En algunos de ellos, los aspectos literarios como el estilo o la corriente a la que pertenecieron, predomina. La historia queda como una anécdota o un sustento para su argumento. Ahí resurgen mis argumentos planteados a lo largo de este escrito: la historia no debe ser ajena a la poesía. Ambas pueden habitar un argumento, un mismo texto creador y contenedor de conocimiento.

En esas publicaciones resalta la utilidad de la poesía como una fuente informativa para la historia. Sin embargo, observo una carencia: la poesía guía cada trabajo, los autores reconocen a los versos como una fuente descriptiva, expresiva y evocativa de un hecho; resaltan su habilidad e incitar el imaginario de la humanidad o la identidad nacional; no obstante, ninguno habla de cómo utilizarla. Los autores no advierten, por ejemplo, de la relación inquebrantable entre quién y dónde existe la poesía. O del valor artístico de la poesía. A partir de esa discusión, busco argumentar sobre la inclusión y cohesión de la poesía, sus vínculos y su valor artístico en un documento histórico.

Al categorizarlo como arte, el poema adquiere utilidad y veracidad. Se vuelve algo tangible, documental, funcional para establecer el mundo aprehensible y perceptible de quien lo crea; además, pertenece a un lugar y un espacio, existe para resaltar su verdad. El poema vuelto obra de arte, simboliza la existencia histórica de un pueblo pues encarna un prototipo social. Representa la experiencia de un individuo inmerso en la realidad que se hace de sí misma una sociedad (Silva, 2017). Allí radica su funcionalidad utilidad dentro del pasado de una cultura.

Para entender el párrafo anterior, debe retomarse un argumento de Martín Heidegger (1973): la cosidad, la existencia natural de una cosa. No cabe duda que la obra de arte es un simple objeto. Sin embargo, ese algo reúne las propiedades y la multiplicidad de los sentidos para concebir una forma. De esa manera, el objeto determina el ordenamiento de la materia; 
es decir, su propia manera de existir. Por último, debe servir para algo, debe tener una utilidad para mostrar la verdad de ella misma.

Cuando una cosa se crea "se dice que también está hecha de ella [misma]." (Heidegger, 1973, p. 66). Esta frase, por demás compleja, plantea el objetivo de cada objeto: tratar de establecerse y preservarse en el mundo. En otras palabras, volverse verdadera. Debe entenderse esto último como algo concordante con todo: con el "ahora" al momento de ser creada. Una cosa verdadera se muestra tal y como es; enseña la totalidad de ella misma y sus propiedades.

No basta con ser un objeto, lo artístico de la cosa acontece en y para la verdad. Insisto, por verdadero no debe decidirse entre lo factual o lo falaz, lo correcto o lo erróneo. Más bien, plantearse el concepto de acontecimiento y de razón en el presente - la desocultación del ser para Heidegger-. Una obra simboliza la expresión humana de un presente, en una interpretación de la realidad temporal-espacial. Un instante, un momento de creatividad, una cosa en la existencia del hombre. Lo verdadero sucede en el ahora de y quien crea la obra.

Además, la obra de arte representa la razón del tiempo presente. De acuerdo con Pérez Cortés (2013), "la racionalidad de esta manera de percibir el tiempo no es lo actual, sino los momentos objetivos, exactos y válidos que orientaron al ser humano en su actuar creativo.” (p. 26). Al ser un producto de los símbolos, de lugares y tiempos específicos, la pieza artística significa y realiza el momento de su creación. Esos productos no pueden desarraigarse del ser humano. Una obra no sólo soporta su naturaleza cósica, su verdad; también forma parte de los momentos y situaciones humanas.

La contemplación de la obra no aísla al hombre de sus vivencias, sino que la inserta en la pertenencia a la verdad que acontece en la obra, y así funda el ser-uno-para-otro y el ser-uno-con-otro como el histórico soportar el existente (Dasein) por la relación con la no-ocultación. (Heidegger, 1973, p. 91). 
La verdad artística en la poesía no debe buscarse sino ponerse en acción. El filósofo italiano Sergio Givone (2013) escribió: “La verdad está enmascarada, tampoco se le conoce al desenmascararla, sino quizá poniéndola en escena [...]” (p. 116). Estas palabras enaltecen la ambición humana por simbolizar para expresar su realidad. La poesía alcanza su verdad cuando se ata del poeta, el poema y la realidad. El escritor dota de propiedades humanas a lo infinito, lo significa en una cosa para arrojarlo al escenario. La tercia irrompible alcanza su verdad y razón artística cuando revela el tiempo de sí misma.

Ahora bien, si un poema es una cosa que alcanza la categoría de obra de arte, entonces es una cosa donde se reúnen las propiedades y la multiplicidad de los sentidos de la poesía, para concebirse en una forma humana. Esa forma determina el ordenamiento de lo poético en la realidad de quien la escribe, en la del poeta. Su utilidad recae en revelar la verdad (de ella misma) para establecerse y preservarse en el mundo. La poesía se vuelve verdadera y útil cuando se muestra tal y como es en un poema. En ese texto enseña la totalidad de sus propiedades.

"El arte como instauración es esencialmente histórica" (Heidegger, 1973, p. 101). Esto no significa que el arte tiene historia y se crea por sí misma. Al contrario, no es un ser independiente que se transforma dependiendo su voluntad. Más bien se adapta a sus creadores y contempladores, a la existencia histórica de un pueblo. La poesía puede pertenecer a esta definición también. Ella no se modifica a su voluntad, al ser un vínculo inquebrantable con la realidad, entonces pertenece a la realidad, dependiente y cambiante del contexto donde fue creada.

Como el poema es una cosa real y útil, las culturas o civilizaciones pueden manifestarse lingüísticamente en ese documento. La poesía baila al son de la capacidad del 
hombre por expresar su realidad. Por esa razón, todo poema se logra a través de hechuras finas, se teje con hilos suaves pero inquebrantables. El lenguaje tiene la tarea de fundar la razón del poema, su escritura y creación; es la forma, la materialidad y la huella de un contexto. La obra de arte es posibilidad y límite a través de la lengua.

Con base en el lenguaje humano, la poesía sirve y otorga un tipo de información muy particular: el instante poético. Ese momento brinda de sentido a un tipo de escritura, a una que habla de otro tiempo y que puede leerse de manera pura en el presente. Es decir, desde la lectura del ahora se puede conocer la pureza del ayer. El criterio temporal juega un papel clave para entender e innovar la posible unión disciplinaria: el instante no sólo alude al horizonte atemporal del pasado, sino a un tiempo y espacio precisos donde se desenvolvieron los acontecimientos históricos. Ese lapso contiene una peculiaridad pasado-presente sobre los hechos.

Un instante poético puede analizarse en tres niveles y criterios: el descriptivo, el expresivo y el evocativo. Los primeros dos surgen del trabajo del escritor. El autor otorga memoria a su acción. Realiza su trabajo con palabras. El tercer nivel, el evocativo, ocurre cuando un lector toma el libro de poesía entre sus manos y lo lee. Él hace hablar al recuerdo. Consagrar un instante implica escribir para ser leído. Esa tercia analítica sirve para quitar los velos posados sobre el valor del instante.

La descripción se realiza con base en una red semántica. El poeta escribe palabras. Además de sólo decir, ellas expresan el mundo de su autor, sea o no de manera intencional. Creador y creación vuelcan en letras articuladas a la percepción de una realidad, de una existencia y en muchos casos, de un hecho concreto. Esas palabras describen y expresan, pero también evocan los momentos consagrados. Como una epifanía, ellas se liberan cuando el mismo poeta las nombra y un lector las mira. La evocación revive la descripción y la 
expresión de una experiencia y percepción del mundo. La consagración del instante cristaliza un testimonio. Ése es recogido desde el presente del creador y del lector.

El poema va a estar hecho de palabras que a su vez corresponden a un lugar y a un tiempo en específico; está ligado al cuándo, dónde y quién lo creó. Detrás de toda producción escrita hay también un reflejo de los seres humanos que sienten, hablan y viven; que captan y expresen su realidad; que piensan y generan imágenes mentales; que escriben, pero conversan sobre la trascendencia de lo cotidiano (Viñao, 1996). Con el lenguaje toman forma experiencias, realidades, palabras y cosas, una obra de arte. Así, el lenguaje del poema es capaz de encarnar su propio significado para después expresarlo en una realidad.

Al reducir todas sus posibilidades a un vínculo inquebrantable con el poeta, el poema y la realidad donde fue creada, la poesía comienza a rodearse de límites. Esos mismos límites la vulneran y la contienen a la existencia de un hombre y su capacidad por dialogar y plasmarla en un documento. Ese testimonio tiene utilidades, como se explicó en párrafos anteriores; sin embargo, también contiene barreras. La poesía no puede controlar otros dominios o vínculos ajenos a ella.

\section{Los límites de la poesía en la historia}

Los límites de la poesía en la historia surgen desde sus virtudes humanas: su vínculo con la realidad del poeta y su manifestación en un poema. Al volverse palabras, su esencia, junto a sus posibilidades infinitas, se tornan en algo familiar y reconocible. Cualquier persona puede observarla, leerla o creerse capaz de valorarla. Así surge "el prejuicio germánico en favor de la llamada profundidad" (Pfeiffer, 1959, p. 13). Es decir, a la poesía se le comienzan a exigir

problemas, así como ideas e información. Sus lectores la encasillan dentro de una configuración verbal o una categoría literaria. 
El límite más grande de la poesía sucede al ser escrita por un poeta, al quedar atrapada en tinta y papel. La escritura siempre será una atadura; una fuerza que sujeta lo imaginado para después visualizarlo. Cuando queda escrita gana sentidos, palabras y signos útiles para representar un fenómeno. La escritura busca a lo Otro. Abrirse a la otredad sirve para descubrir las verdades propias en otro cuerpo. Cuando el poeta la toma para escribirla, la poesía se expulsa de sí misma; incluso se mira en las hojas del poema, para después entenderse como un entramado o conjunción verbal.

Al ser identificada de esa manera, la poesía adquiere aún más características limitantes. Cada una de esas palabras la vuelven reconocible, la encierran en ritmos, imágenes y metáforas. Cuando hablo del ritmo, me refiero a una cantidad inconmensurable de vibraciones resguardadas en un poema. En cada uno de esos sonidos, la poesía descubre sus secretos: a veces acelera melodías, en otras se vuelve cadenciosa o provocadora; ondulada o vibrante. Utiliza sus ritmos para orquestar el flujo de los versos.

Al ser una de sus características primordiales, el ritmo varía en sus formas de suceder. Parece tener raíces somáticas y psicológicas impresas en los pliegues y texturas de la poesía (Eagleton, 2007). A veces aparece como un simple tropezón. Otras ocasiones, mantiene un tono alto, ascendente como la voz de un tenor. En algunas más derrumba todo a su alrededor. El ritmo revela los sonidos capaces de atrapar a la poesía, pero también la contiene en el aquí y el ahora de un poema.

A pesar de esa musicalidad, las palabras necesitan de significación. El lenguaje impreso en el ritmo de la poesía se entiende a través de imágenes. El complejo verbal no sólo se configura rítmicamente, también se articula de forma sintáctica y semántica. Con base en las palabras y sus sonidos, crea imágenes para ser entendida. Así, al usarlas, logra transmitir 
y recibir lo común o cotidiano, se vuelve en algo reconocible. Una imagen es la moneda de cambio para el trato y comprensión cotidiana de la poesía.

Para Michel Foucault (1968), “el lenguaje vale como signo de las cosas.” (p. 41); sin embargo, difiero de lo dicho por el filósofo francés. La imagen convierte y dota al lenguaje de elementos entendibles. Por esa razón, las imágenes son la consecuencia o la causa de la distancia entre las cosas y los observadores, no sólo el lenguaje. La poesía necesita transformarse para adherirse en algo visible-entendible. Ahí comienza un proceso de adaptación y entendimiento en quien mira a la poesía de forma atenta.

Las imágenes también provocan una renovación poética. Es decir, al surgir uno y mil símbolos-visiones, la poesía se ordena, clasifica, comunica, relaciona, transforma y actualiza los intereses de quien la lee. De esa manera, cada una de las imágenes poéticas ordena intenciones: adquiere forma y significado para sus observadores; crea referencias reconocibles. Esas representaciones de lo poético permiten llegar a relacionar lo desconocido a través de lo visible.

A pesar de la posible relación, existe también una dificultad. Las imágenes pueden concentrar millones de opciones: colores, figuras, género, número, tamaño, superficie, costumbres, y lo que guste añadirse. Estos elementos siempre diferirán de los espectadores. La poesía es capaz de producir una incontable cantidad de imágenes. Ella se escucha, se cavila, y se observa desde la pluralidad de sus imágenes; es producto de quien la oye, la mira, la escucha, la repite, la siente, y la imita.

Toda la poesía está llena de imágenes en este sentido, porque es una facultad irrenunciable del lenguaje su poder de dar a ver, de hacer ver, de hacer referencia al mundo de todos los días: al mundo real. (Blanco, 2014, p. 123). 
En la imitación descansan las palabras, los ritmos, las imágenes y las metáforas. Vuelvo a los argumentos de Foucault (1968): las imágenes indican semejanza, no homología “pues su ser claro y distinto de signatura se borraría en el rostro cuyo signo es [...]." (p. 37). Una imagen representa y asemeja las cualidades de la poesía. Sujetada de las palabras, habla e intenta imitar a la poesía. Una imagen no es exacta, pero en ella se acuña lo posible. Ahí surgen las metáforas: la fiel herramienta de la palabra, los sonidos y las imágenes pues brinda reflejos de las cosas.

Una metáfora no sugiere principio, sino continuación. No hay palabras originales, cada una metaforiza otra palabra, que a su vez se originó de otra. Lo dicho en este documento, se ha argumentado ya de otra manera. Las palabras, el ritmo, las imágenes, las metáforas siguen ese patrón. La fijeza es momentánea y, en consecuencia, la metáfora imparable. A pesar de su constante movimiento, surge el límite más dominante para la poesía pues revela —más allá de todo simbolismo- aquello que nunca se podrá poseer.

Según Pfeiffer (1959), las metáforas logran lo que el arte pictórico jamás podrá acercarse: "abarcar de un aletazo la totalidad de lo existente, conjurar la totalidad de lo existente." (p. 40). Metaforizar es un acto de expresar, de manera distinta, lo irrepetible. El conjunto de palabras, el ritmo e imágenes utilizadas por la poesía pude convencer de su entendimiento. Las metáforas limitan a la poesía y al mismo tiempo le permiten abrir una pequeña ventana de su mundo.

Así se presenta un límite más: el poeta, quien captura la totalidad de un todo en un momento. Es cierto que el escritor libera a la poesía de su cárcel, de sus ilimitadas significaciones para volverla tangible y entendible. Pero no se puede desmentir que el poeta es el límite más grande de la poesía, pues crea todas las palabras, ritmos, imágenes y metáforas. Él aspira a dar cuenta, a expresar y recrear su realidad. No se limita a expresarla, 
también necesita bautizarla, a arrancar las palabras directamente del mundo, para después dislocarlas y ordenarlas según sus intenciones y funciones.

Los poetas parecen tener una sensibilidad especial para ver las diferencias y las similitudes entre la poesía y la naturaleza. Incluso podría decirse que la imitan. Pero el papel del poeta no sólo es la de copiar, sino utilizar su lenguaje para destruir primero las semejanzas y contrastes. A partir de esas ruinas, el escritor comienza a construir palabras, ritmos, imágenes y metáforas lo que debería o podría ser útil para la existencia del hombre. Su visión posee una sensibilidad vertida en un lenguaje revelador.

Pero eso no es todo. A pesar de las posibilidades que le brinda a la poesía, el poeta es un ser humano y como tal debe reconocer que su lenguaje tiene límites insuperables; los de su propia realidad. El escritor es un artista, un demiurgo siguiendo la filosofía y definición platónica, donde su lenguaje tiene un papel inaugural y finito del discurso. Funda para agotarse en sí mismo. El límite humano de la poesía surge cuando al poeta se le angosta y no le alcanza su vocabulario para nombrar su propio mundo y los que están más allá de él. El lenguaje de su creador es virtud y cárcel.

Desde la perspectiva del poeta y retomando las palabras de Wittgenstein (1997), el lenguaje tiene una dualidad: es herramienta y problema del conocimiento humano cuando se agota. De ahí la famosa frase, “Los límites de mi lenguaje son los límites de mi mundo” (p. 143) Sin embargo, esa frase debe interpretarse como la carencia de lógica en el ser humano. Qué pasa cuando se llega al límite. Los conceptos dejan de tener una referente real y verificable en la realidad. En ese momento, cuando el poeta muestra incapacidad de hablar, de resignificar, la poesía encuentra su límite y su utilidad para la historia.

Así se cierra un círculo planteado desde el principio de esta investigación: la poesía debe vincularse y empaparse de las propiedades humanas originadas en el poeta, su realidad 
y su obra. Esa es su fortaleza y su debilidad. Todos esos elementos forman una relación inquebrantable que le permite volverse parte de la historia. La poesía habita y se adapta en la realidad y límites lingüísticos del poeta: el poema, para realizarse en una obra única.

La poesía será entonces un discurso limitado y lleno de virtud humana. En ella caben todos los discursos y todas las posibilidades, es el espacio de lo sugerente, de lo absurdo, de la falacia. Es el campo del lenguaje, de todas las palabras ritmos, imágenes y metáforas que el hombre puede arrancarle al mundo para después convertirse en Babel (De la Torre, 2010). El espacio donde se puede fundar todo, donde se puede revelar hasta la más mínima trasparencia del habla.

Los límites humanos no sólo atan, transforman a la poesía en una obra de arte. Vuelta un producto artístico, expone las exigencias de una época, de un ambiente cultural y de la idiosincrasia de su autor. En palabras simples, la poesía, asida del poeta, queda plasmada en un documento. Éste adquiere valor artístico si referencia al pasado con base en la existencia y la capacidad del poeta por describir, expresar y evocar un momento de su realidad. El arte es una reciprocidad entre creación y creador. La poesía necesita del poeta y del poema para revelarse en el terreno histórico y viceversa. Una obra de arte testimonia las exigencias de vida, individuales y colectivas, de su creador.

Así es como la poesía funciona como una herramienta más para recrear algún hecho del pasado. La reelaboración del ayer se vincula de manera directa e innegable con los métodos y las fuentes históricas. Lo poético aporta información pues muestra una relación de doble vía con el pasado: tanto la dinámica de una sociedad desenvuelta en diversas coyunturas -políticas, sociales, culturales, económicas, incluso militares-, como en coordenadas espacio-temporales precisas. Las letras no pueden arrancarse del ayer. La 
historia tampoco puede omitir el vínculo poeta-poema-realidad como un contenedor de testimonios. Así la poesía involucra maneras de registrar hechos y acontecimientos.

La poesía plasma la forma de actuar de individuos, de grupos y de sectores sociales ante las circunstancias y los hechos. El poeta no sólo contextualiza social e históricamente a sus escritos, sino también a él mismo. Al hacerlo, busca su individualidad a través de los factores sociales que lo influyen, lo determinan y lo rodean. La reciprocidad es inminente. Escritor y texto se integran y se corresponden a partir de un sinfín de nexos socioculturales. En otras palabras, las obras poéticas resultan ser un producto humano intervenido por el conjunto de factores espacio-temporales.

La poesía puede utilizarse como un recurso para la indagación histórica. Su discurso y narrativa la diferencian de otras fuentes como crónicas, intercambios epistolares, registros etnográficos, fotografías, diarios, y un gran etcétera de documentos. Sin embargo, su principal virtud y límite sucede cuando éstas se desarrollan alrededor de un tiempo y un espacio precisos. Al referirse a un momento en la historia, ellas enseñan la perspectiva de un autor influido por su contexto sociocultural. Lo poético comienza a actuar como un instrumento de denuncia, contraste, adición o crítica de la información sobre el pasado. 


\section{CONSIDERACIONES FINALES}

La poesía, en este sentido, es una forma de arte que se vale del lenguaje para expresarse: nada más y nada menos que un humilde, pero orgulloso, género literario. Un oficio sui generis que tiene como materia prima las palabras -las de un idioma en particular- y como herramientas la sensibilidad y la imaginación del poeta así como todos los elementos que conforman el lenguaje y que le dictan lo mismo sus limitaciones que sus ecos.

Alberto Blanco

La poesía aporta información sobre el pasado porque muestra la dinámica de una sociedad, desenvuelta en diversas coyunturas, en coordenadas espacio-temporales precisas. Las letras no pueden arrancarse del ayer. La historia tampoco omite el vínculo poeta-poema-realidad como un contenedor de testimonios y acontecimientos. Atada del poeta, sus palabras y un texto, lo poético suma conocimiento e información. Si lo poético ayuda a recrear un hecho, entonces también debe criticarse la información que contiene.

Esta investigación se originó desde un objetivo principal: descubrir y revelar el valor de la poesía como una fuente de conocimiento histórico. La poesía parece un ente indefinible hasta que el poeta la toma y la transforma en una obra de arte para otorgarse al conocimiento histórico. Ahí el pasado puede estudiarla con base en los instantes poéticos, en el lenguaje. La poesía forma parte de la historia cuando sus palabras logran manifestar el lenguaje de un hombre y de un hecho en específico.

El lenguaje relaciona objetos y signos para después encarnar algo. Esto parecería una limitante, más que una virtud. Sin embargo, el lenguaje debe verse como algo en constante y poderoso movimiento. No sólo sirve para designar una cosa, sino distintos tipos de objetos, ideas o sentimientos. Borges atinó al definirlo como un surtidor donde cabe un sinfín de posibilidades. El lenguaje posee una creatividad-polisémica que se adapta a las necesidades de quien lo utiliza. 
El hombre, como un ejemplo concreto de adaptación, lo manipula para transmitir su propia cultura, emociones o experiencias. Ambos se corresponden para lograr un acto de concepción sobre esto y aquello. Juntos construyen un inventario de las cosas o los seres. Gracias a la lengua, la humanidad ha podido abonar un terreno donde es capaz de indicar, emocionar o representar. Esto lo pienso como un acto de liberación recíproco: ambos se expresan, se vuelven tangibles, para después habitar el mundo.

Expresar y habitar el lenguaje son conceptos distintos. El acto de expresión contiene una utilidad coloquial, aunque necesaria: pensar, hablar y dar a conocer. Por la boca del hombre brotan signos que lo comunican. Al hacerlo, transmite la forma de su consciencia e inteligencia. Por otra parte, habitar el lenguaje significa algo un poco más complejo: apelar a lo otro. Dejar a un lado los fines pragmáticos del lenguaje y dar un paso más allá de la simple transmisión: entonar otra voz, algo más allá de lo común. Por estas razones, el ser humano utiliza y maneja al lenguaje para poder expresar, habita y significar -de una o muchas maneras- su propia existencia.

Con base en lo anterior se origina la primera consideración final de este documento: la poesía posee y transmite conocimiento histórico a través del lenguaje humano capturado en un poema. Esta idea se desarrolla como un proceso: la poesía no puede enunciarse ni alojarse en el mundo por sí misma. Necesita de alguien capaz de guardarla en una creación manifiesta. El poeta se elige de entre los hombres para idealizarla. Así comienzan un recorrido de expresión y radicación. El poeta y su lenguaje mantienen una relación recíproca donde ninguno existe sin el otro. Atada de ese personaje, la poesía también comienza a significar, expresar y habitar la realidad de su creador.

Con sus acciones y palabras, el poeta hace entendible a la poesía para donarla al conocimiento histórico. El escritor confía en su lenguaje: quien es producto de su tiempo y 
realidad. Su capacidad lingüística establece un sistema de diferencias e interacciones donde todos los elementos comienzan a definirse y a significarse. Sólo a través de ese recorrido, unida del poeta, la poesía se consagra en una obra que puede ayudar a la reinterpretación de algún hecho ocurrido.

Ahora bien, la historia debe ser recreada a partir de vestigios tangibles. Ante esa necesidad, el poeta sitúa a la poesía dentro de un documento correspondiente a una trama social: el poema. Ese documento se encarga de armonizar, configurar y manifestar verbalmente a la poesía. No sólo dice, también significa y delimita la relación entre lo inalcanzable y el lenguaje del hombre. El poema es un ser alimentado por las palabras de un hombre inmerso-existente de un tiempo y espacio específico.

Las palabras del poeta son tanto suyas como de los demás. Pertenecen a un pueblo, una cultura; son fechables. Con ellas se pude dar cuenta de las expresiones de una sociedad pues nombran esto o aquello; referencian y significan el mundo donde un grupo de hombres habitaron un momento en el pasado. El poema es el sitio donde se encarnan la palabra, la historia, el poeta y su cultura. Como toda creación humana, se produce en un tiempo y gracias al lenguaje. De esa manera, el hombre dota y limita a la poesía con cualidades lingüísticas para que tenga un lugar en el proceso de la vida humana.

Lo anterior busca confirmar el punto desarrollado en el primer capítulo de esta investigación: el poeta significa la relación entre realidad y lenguaje. Crea un poema que resulta y depende de las distintas exigencias de cada época, del ambiente cultural y de la idiosincrasia del autor. A pesar de las variantes, el poeta se adueña de su tiempo-espacio y lo recrea a través de palabras, de instantes. Ese resultado adquiere una fuerza interpretativa individual-colectiva de una realidad. 
En ese mismo apartado se resaltó la utilidad histórica de la relación inquebrantable que mantiene la poesía con el poeta-poema-realidad. El poeta abre un diálogo entre hombres y dioses para brindar de permanencia a las palabras. Une su lenguaje con los hechos a su alrededor para crear un testimonio de la unión, un poema. Con esa creación es posible enriquecer la comprensión de hechos históricos. Con base en ese vínculo irrompible descansa la utilidad y el papel de la poesía como fuente informativa del pasado.

Para demostrar tal unión, el trabajo abarcó algunos momentos en la existencia de Walt Whitman; desde su nacimiento hasta la conclusión de la Guerra Civil (1819-1865). Durante esos años se pudo ligar las vivencias individuales con algunos elementos culturales, políticos y sociales desarrollados en la obra del poeta. Su niñez, los problemas familiares, su autoeducación, sus labores periodísticas, y su actividad de enfermero tenían una relación directa con distintas situaciones nacionales. En cada instante de vida, se pudo conocer la interacción entre individuo, obra y realidad.

Al no abordar toda una vida, se pudo indagar en los momentos de mayor lucidez en el Whitman. Más allá de su infancia y formación intelectual, la Guerra Civil es un apartado relevante: su paso por hospitales mermó su salud, pero dichos episodios motivaron un cambio, un despertar, en sus letras. La historia de su vida no sólo apuntó a su extraordinaria voz poética, sino a instantes de dolor, sufrimiento y vulnerabilidad. A partir de su vida y obra se pudo explorar al escritor, a las regiones ocultas en su pensamiento, mientras aspectos culturales, políticos y sociales también se consideraron.

El argumento sobre la Guerra Civil es el lugar donde se puede leer y ahondar en la relación inquebrantable entre poeta-poema-realidad. El enfrentamiento entre unionistas y confederados puso en tela de juicio todos los ideales no sólo de Walt Whitman, sino de los propios Estados Unidos. Fue en el poemario Redoble de tambor donde se contuvieron las 
esperanzas de una nación cimbrada, así como las experiencias propias del poeta. Esos poemas también testimoniaron experiencias individuales y colectivas: el avance de los ejércitos, el terror de las batallas, la camaradería, el deseo, el afecto y la idea de unión. La obra del poeta comenzó a servir como una memoria de la historia nacional.

El poeta significa la relación entre realidad y lenguaje. Crea un poema que resulta y depende de las distintas exigencias de cada época, del ambiente cultural y de la idiosincrasia del autor. A pesar de las variantes, el poeta se adueña de su tiempo-espacio y lo recrea a través de palabras, de instantes. Ese resultado adquiere una fuerza interpretativa individualcolectiva de una realidad. Como tal, puede servir para entender los hechos sucedidos en algún momento en el pasado.

De esta manera surge la segunda consideración final de este trabajo: el tipo de información recuperada del trabajo del poeta. Al haber indagado en la vida de Whitman, se conoció su experiencia durante el conflicto. Sus primeros versos guardaron patriotismo y júbilo. Así también, el cambio de entonación fue algo difícil de ignorar. La investigación retomó algunos los puntos anteriores para analizar los versos del poeta a partir de tres propiedades útiles para la historia: la descripción, la expresión y la evocación.

Con esta tercia analítica se elaboró una relectura de Redoble de tambor. Esto permitió observar los instantes logrados por el poeta sobre el conflicto, los cambios y los estragos de la Guerra de Secesión. Ese poemario guarda un collage de testimonios, de valentía, así como del salvajismo de la guerra; de la misma manera, recoge la voz de los involucrados, así como la de los contempladores del conflicto. En ese mosaico se pudieron ver las posturas tanto a nivel individual como social respecto del conflicto estadounidense.

El sonido del tambor mostró los marcos sociales. Las vivencias de Whitman no fueron exclusivas, pertenecieron a una idea colectiva y común sobre las hostilidades. Los poemas 
trabajaron como nociones comunes para reconstruir una realidad a partir de datos en conjunto. Aunque el poeta escribió desde su propio genio y visión, las palabras y experiencias plasmadas formaron parte de una misma sociedad. Cada poema de Redoble posee una perspectiva personal, aunque conjunta sobre hechos de la Guerra Civil.

Los marcos sociales se transformaron fueron la base de los recuerdos individuales de Whitman. Cada persona que interactuó con él le proporcionó fechas, nombres, nociones, patrones de experiencia, así como formas de razonamiento y pensamiento. Es una suma de elementos entre el creador de versos y su contexto o realidad social. Esos marcos son de ayuda cuando se busca reinterpretar u ordenar los sucesos sobre un hecho. Así se crea una memoria conjunta y coherente sobre algún suceso. Una memoria individual pierde valor si no se completa o compara con la de otros.

No sólo los marcos sociales, la investigación también señaló el pensamiento en común sobre la Guerra Civil: un infierno terrenal. Whitman obtuvo ese pensamiento gracias a la lectura y análisis de La divina comedia. Asimismo, en 1862, no sólo buscó a su hermano menor en el campo de batalla, también compró, leyó y analizó aquel libro. Relacionó al poema medieval con los eventos de su nación. El infierno dantesco influyó de manera directa en el estilo y los objetivos de Redoble.

Si hubo una constante en la Guerra Civil fue su extrema violencia. Confederados y unionistas se enfrentaron en batallas encarnizadas. Los estragos, el terror y las pérdidas humanas en el conflicto le dieron a Whitman una razón suficiente para asemejar la realidad con las metáforas dantescas: un lugar caótico, lleno de sufrimiento, la muerte encarnada. El poeta encontró una medida de inspiración y relación poética. La Comedia le brindó un símil o una referencia de la violencia desproporcionada. 
Otro tipo de información otorgada por el poeta fue el cambio de perspectiva hacia la Guerra Civil. Al principio, el optimismo se desbordaba. Las hostilidades eran la mejor manera de resolver diferencias. Después, el caos y la desesperanza confirmaron el infierno terrenal. En la recta final de la guerra, la incertidumbre reinó: algo debía ocurrir para alcanzar una solución. Whitman pensó en la reconciliación democrática tras leer la Comedia. Los hechos debían concluir de manera benéfica, no sólo para las regiones, sino para toda la nación norteamericana.

Whitman y su Redoble enfatizaron en una reconciliación para terminar la guerra. A las diferencias debía seguirle una resurrección cimentada en el espíritu de unión. Sus poemas recogieron el impacto, la inmediatez y la brutalidad de las escenas y recuerdos de guerra. Obra y poeta ofrecieron una lectura capaz de dar información sobre la postura cambiante respecto de la guerra: desde la valía de las causas y el orgullo por defenderlas, la verdad de los horrores y la obtención de un ideal de reconciliación.

Así llega la última consideración de este trabajo. A pesar de ser una visión sobre algún acontecimiento, la obra del poeta también sirve como una herramienta informativa para la historia. Para ello necesitó ser criticado, complementado o refutado como contenedor de información. Aunque fue la guía del genio de Whitman, la poesía no fue la única fuente utilizada. La correspondencia, libros de texto, incluso diferentes versiones de los poemas sirvieron para recrear fragmentos de vida individual y nacional. Sin embargo, esos documentos poseen una fuerza muy distinta a la de otros documentos: los instantes poéticos; los capaces de describir, expresar y evocar un hecho particular.

Cada instante poético nunca podrá ser entendido por sí solo. Por supuesto que existen momentos logrados con simpleza: dirán sólo lo escrito ahí y no más. Una cosa puede ser una simple cosa. Una guerra o una vida sólo serán eso. No obstante, también existieron momentos 
donde se apreció el contexto social, cultural, o político. Con ello se puede entender la retórica, los sonidos o silencios. Un poema debe ser completado o contrastado con otras fuentes para enriquecer su pertenencia dónde y cuándo fue creado.

El estudio de la verticalidad de los instantes descansa en tres categorías: la descripción, la expresión y la evocación de un hecho. El primero, enuncia la situación del mundo; la relación literal de las palabras con los acontecimientos. El segundo expresa la visión individual y conjunta del mundo, algo primordial para recrear y entender el pasado. El tercero actualiza las palabras y los significados para evocar el pasado en el presente. No sólo los poemas de Whitman, cualquier texto de esta naturaleza puede ser estudiado con base en las tres propiedades del instante poético.

Con base en las tres características del instante, se pudo acercar a otra perspectiva de la historia. La poesía contiene un tipo de lenguaje, creación e incluso vocabulario, pero no deja de aportar conocimiento sobre momentos pasados. Su valor documental recae en saber qué leer y entender cómo habla el poeta, en mirar las descripciones, expresiones y evocaciones. La lectura de una obra literaria, como un poema, implica entender subtextos y contextos para encontrar información. Los poemas no omiten su valor y contención de datos debido a los instantes poéticos que resguardan.

Lo último que se debe considerar para plantear el acceso de la poesía al estudio del pasado debe ser su narrativa. Al pertenecer a un entramado lingüístico entre el poeta, el poema y la realidad, la poesía adquiere características de un relato, se convierte en algo apto y específicamente cultural. En un concepto retomado de Hayden White (1992), la poesía podría ser considerada como un metacódigo universal humano. A través de ese código es posible trasmitir mensajes transculturales acerca de una realidad común. 
No basta con ser un código capaz de transmitir información. También debe seguir un orden en la cronología de una realidad. Tras haber estudiado y desarrollado algunos de los momentos en la vida de Walt Whitman, su poesía no apareció de manera espontánea. Poeta y obra siguieron un ritmo, un proceso intelectual de formación que la hizo referente de un momento en el pasado. La poesía también sigue un discurso ordenado: presenta los acontecimientos en orden de sucesión.

Los momentos capturados y ordenados en los productos poéticos, informan, documentan y relatan la visión de un autor sobre una realidad experimentada. Si un poema estremece, informa o emociona, se debe a la reflexión del lector sobre el instante encontrado en el poema. Los documentos de la poesía así sus creadores pueden considerarse como informantes estéticos que van más allá de la interioridad y subjetividad individual. Al leerla, la poesía permite al lector asirse de ella y hacerse con ella.

Mi investigación intentó demostrar las posibilidades de la poesía en el terreno de la historia. Esto sucedió a través de la existencia y el trabajo de un autor. Con su obra se pudo enriquecer la información sobre un hecho histórico. Así surgió la relación inquebrantable entre poesía e historia mediada por la presencia del escritor. La poesía logró testimoniar tanto al individuo, su contexto y su obra por medio de una relación recíproca e irrompible.

Todo lo anterior no pudo haber sido planteado sin el lenguaje. Así se termina esta investigación, con el uso de la lengua, de las palabras para interiorizar y socializar el contenido de un texto poético. En los productos de la poesía se ofrece información para enriquecer el conocimiento sobre el pasado. Cada vestigio resguarda una visión simbólica de un contexto, pues corresponde y comunica un contenido conceptual del pasado. Como se insistió en este escrito, la poesía también presume esa capacidad. Ella sirve como una herramienta más para la historia siempre y cuando se sepa leer, cuestionar e interpretar. 


\section{BIBLIOGRAFÍA}

\section{FUENTES DE ARCHIVO}

Walt Whitman Archive (WWA). American literature must become distinct. Recuperado en abril 2020, de [https://whitmanarchive.org/manuscripts/transcriptions/rut.00010.html].

. Chronology of Whitman's life. Recuperado en junio de 2019, de [https://whitmanarchive.org/biography/chronology.html].

. For remember that behind all. Recuperado en octubre 2020, de [https://whitmanarchive.org/manuscripts/transcriptions/loc.05334.html]. . such a thing as ownership. Recuperado en junio de 2019, de [https://whitmanarchive.org/manuscripts/transcriptions/med.00740.html].

. The idea of reconciliation. Recuperado en abril 2020, de [https://whitmanarchive.org/manuscripts/transcriptions/loc.05180.html].

. Walt Whitman to George Washington Whitman, 12 July 1861. Recuperado en Julio de 2019, de [https://whitmanarchive.org/biography/correspondence/tei/duk.00378.html].

. "Walt Whitman to Louisa Van Velsor Whitman, 29 December 1862. Recuperado en Julio 2019, de [https://whitmanarchive.org/biography/correspondence/tei/loc.00758.html].

\section{BIBLIOGRAFÍA}

Abdullah, A. S. (2014). Walt Whitman's Drum-Taps: shifting Attitude towards the Civil War. International Journal of English Language, Literature and Humanities, Vol. II, Núm 3, Julio 2014, 1-14.

Adams, W. P. (1979). Los Estados Unidos de América. (24a edición en español). Ciudad de México: Siglo XXI.

Álvarez, O. J. (2013). La Poesía, El poema y El poeta. Una aproximación a la poética como conocimiento. Universidad Pontificia Bolivariana, Medellín, vol. 21, Núm. 46, enerojunio, 223-242.

Bachelard, G. (1999). La intuición del instante. (2 edición). México D.F.: FCE.

Balcázar de Bucher, C. (2006). Lenguaje, poesía y filosofía. Revista de estudios sociales, 62-80.

Bermejo, J. C. (2005). Sobre la Historia considerada como poesía. Madrid: Akal. 
Blanco, A. (2011). El llamado y el don. México D. F.: Auieo. . (2014). La poesía y el presente. (2 edición). México D. F.: Auieo.

Bloom H. (1994). El canon occidental. La escuela y los libros de todas las épocas. (11 ${ }^{\mathrm{a}}$ edición). Barcelona: Anagrama.

Chartier, R. (2014). Cultura escrita, literatura e historia. (2a edición). México D. F.: FCE.

Eagleton, T. (2008). How to read a poem. Oxford: Blackwell Publishing.

Feldman, M. B. (2003). Remembering a Convulsive War: Whitman's Memoranda During the War and the Therapeutics of Display. Walt Whitman Quarterly Review, Núm 23, Verano, 2003, 1-25.

Folsom, E. (2020). A Current Bibliography. Walt Whitman Quarterly Review, Vol. 38, Núm. 1, Verano, 2003, 64-70.

Folsom, E. y Price, K. M. Walt Whitman (2007). Recuperado en septiembre 2020, de Walt Whitman Archive [https://whitmanarchive.org/biography/walt_whitman/index.html].

Foucault, M. (1968). Las palabras y las cosas. Una arqueología de las ciencias humanas, Buenos Aires: Siglo XXI.

Genoways, T. (2006). The Disorder of Drum-Taps. Walt Whitman Quarterly Review, Vol. 24, Núm 2, Otoño, 98-117.

Gibson, Samantha. The Panic of 1837. Recuperado en abril 2020, de Digital Public Library of America [https://dp.la/primary-source-sets/the-panic-of-1837].

Gillis, A. (2014). Poetry an Introduction. En The Edinburg intorduction to Studying English Literature (37-46). Edinburgo: Edinburg University Press.

Gramsci, Antonio. (1972). Cultura y Literatura. (3ª edición). Barcelona: Ediciones Península.

Grant, S.M. y Holden, B. (2010). Themes of the American Civil War. The War Between the States. (2a edición). Nueva York: Routledge.

Gordillo, A. y Flórez, M. (2009). Los niveles de comprensión lectora: hacia una enunciación investigativa y reflexiva para mejorar la comprensión lectora en estudiantes universitarios. Revista Actualidades Pedagógicas, Núm. 53, enero-junio, 2009, 95-107.

Halbwachs, M. (2004). La memoria colectiva. (1º edición al español). Zaragoza: Prensas Universitarias Zaragoza. 
Hauser, A. (1977). Sociología del arte. 4. Sociología del público. Madrid: Punto Omega.

Heidegger, Martin. (1973). Arte y Poesía. (2ª edición). Ciudad de México: FCE. (2009). Tiempo e historia. Edición y traducción de Jesús Adrián Escudero. Madrid: Mínima Trotta.

Hirschhorn, B. (1998). Views on Education. Recuperado en octubre 2020, de [https://whitmanarchive.org/criticism/current/encyclopedia/entry_2.html].

Hollinger, D. A. y Capper C. (1997). The American Intellectual Tradition (Vol. 1. 16301865), Nueva York/Oxford: Oxford University Press.

Jenkins, Philip. (2007). A History of the United States. (3a edición). Gran Bretaña: Palgrave Macmillan.

Kramer, L. (2016). Introduction: Battle Music, Ballads, and Their Afterlives. $19^{\text {th }}$-Century Music, Vol. 40, Núm. 1, 3-5.

Lindeen, Karilyn. (2016). Walt Whitman and the American Civil War: From Wound Dresser to Good Grey Poet. Tesis de Maestría. Department of History. College of Arts and Sicences, Kansas State University.

Locks, C., Mergel, S.,Roseman, P. y Spike, T. (2013). History in the Making: A History of the People of the United States of America to 1877. Georgia: The University System of Georgia.

López Peña, L. (2008). The Role of the Poet in the American Civil War: Walt Whitman's Drum-Taps (1865) and Herman Melville's Battle Pieces (1866). Tesis de Maestría. Universidad de Barcelona.

Loving, J. (1997). Caresser of Life: Walt Whitman and the Civil War. Walt Whitman Quarterly Review, Vol. 15, Núm. 2, Otoño, 67-86.

(1998). Walt Whitman. Encyclopedia of American Poetry. The Nineteenth Century (471-478). Nueva York: Routledge.

(1999). Walt Whitman: The Song of Himself. Berkley: The University of California Press.

(1999). Whitman, Walt. Recuperado en septiembre de 2020, de [https://www.anb.org/view/10.1093/anb/9780198606697.001.0001/anb9780198606697-e-1601761].

Martín, F. (2003). Walt Whitman. Madrid: Síntesis. 
Matthews, J. (2014). Walt Whitman's Vision of the Inferno, or Dante in Drum-Taps. Walt Whitman Quarterly Review, Vol. 32, Núm 1, 36-68.

Mendiola, A. (2005). La inestabilidad de lo real en la ciencia de la historia: ¿argumentativa y/o narrativa? Historia y Grafía, Núm. 24, 93-122.

Miller, C. (2009). Drum-Taps: Revisions and Reconciliation. Walt Whitman Quarterly Review, Vol. 26, Primavera, 171-196.

Mullins, M. (1999). Stopping History in Walt Whitman's "Drum-Taps”. Walt Whitman Quarterly Review, Vol. 17, Núm 1, Verano, 4-14.

O’Neil, Brandon J. "Whitman, Walt. Drum Taps: The Complete Civil War Poems; Drum Taps: The Complete Edition 1865 Edition [review]. Walt Whitman Quarterly Review, Núm. 34, Vol. 34, 82-87.

Öz, F. (2015). “Drum taps: Whitman's Problematic Legacy as a War Poet”. Journal of Literature \& Librarianship, Vol. 5, Núm. 1, Otoño 2015, 31-41.

Paz, O. (1990). La otra voz. Poesía y fin de siglo, México D. F.: Seix Barral. (1972). El arco y la lira. El poema. La revelación poética. Poesía e historia, ( $3^{\text {a }}$ edición). México, D.F.: FCE.

Pani, E. (2016). Historia Mínima de los Estados Unidos de América. Ciudad de México: Colmex / Centro de Estudios Históricos.

Pearcy, A. (2013). Walt Whitman's Changing Perceptions of Effects of the American Civil War and its Impact on his Poetry. Tesis de Maestría. Universidad de Tennessee.

Peck, G. (2015). Walt Whitman in Washington, D.C. The Civil War and Americas' Great Poet. (e-book edition). Charleston: The History Press.

Pérez, S. (2013). La razón en la historia: Hegel, Marx, Foucault. México, D.F.: Universidad Autónoma Metropolitana.

Portela, I. (2008). "Poesía y condición humana, percepción de la angustia y la esperanza, en Poesía y condición humana: habitar la palabra poética. (pp. 73-84). México: Universidad Iberoamericana.

Reynolds, D. S. (1995). Walt Whitman's America. A Cultural Biography, Nueva York: Vintage Books.

Rothbard, M. N. (2007). The Panic of 1819. Alabama: Ludwig von Mises Institute.

Rhodes, J. F. (1917). History of the Civil War 1861-1865. Nueva York: The Macmillan Company. 
Ruiz, F. (2017). Poesía, historia y justicia en América Latina. América sin nombre, Núm. 22, 99-105.

S/A. (1850). Fugitive Slave Act. The Avalon Project. Documents in Law, History and Diplomacy. Recuperado en abril 2020, de [https://avalon.law.yale.edu/19th_century/fugitive.asp].

Seydel, U. (2014). La constitución de la memoria cultural. Acta Poética, Núm. 35-2, julio-diciembre, 187-214.

Siles González, J. (2010). Walt Whitman, Poesía y Cuidados. Cultura de los cuidados. Recuperado en marzo de 2020, de https://culturacuidados.ua.es/article/view/2015n43-walt-whitman-poesia-y-cuidados.

Silva, J. (2017). Gilgamesh o la angustia por la muerte poema babilonio. Ciudad de México: Colmex.

Steiner, G. (1982). El lenguaje y el silencio. Ensayos sobre la literatura, el lenguaje y lo inhumano. Barcelona: Gedisa.

Szczesiul, A. (1993). The Maturing Vision of Walt Whitman's 1871 Version of DrumTaps. Walt Whitman Quarterly Review, Vol. 10, Núm 3, Invierno, 127-141.

Trachtenberg, A. (2000). Loving, Jerome. Walt Whitman: The Song of Himself [review]. Walt Whitman Quarterly Review, Vol. 17, Núm 3, Invierno, 124-128.

Vergara, G. (2005). Miradas que se cruzan. Construcción de la identidad en las poetas mexicanas del siglo XX. Estudios sobre las Culturas Contemporáneas. Época II, Vol. XI, Núm. 22, 291-304.

Villegas Aguilar, P. (2007). Poesía y filosofía. Aproximación a una teoría simbólica de la condición humana, México D. F.: Universidad Iberoamericana.

Viñao Frago, A. (1996). Lenguaje y realidad. El discurso histórico y su aplicación al ámbito histórico-educativo. Anales de pedagogía, Núm. 14, 157-214.

Walker, G. (2014). Poetry and History. En The Edinburg introduction to Studying English Literature (78-87). Edinburgo: Edinburg University Press.

Wayne. W. H. (2011) Total War and the American Civil War Reconsidered: The End of an Outdated "Master Narrative". Journal of the Civil War Era, Vol. 1, Núm. 3, Septiembre, 394-408.

White, H. (1992). El contenido de la forma. Narrativa, discurso y representación histórica, Barcelona: Paidós. 
(2003). El texto histórico como artefacto literario y otros escritos. Barcelona: Paidós / ICE de la Universidad Autónoma de Barcelona.

Whitman, W. (1834). The Olden Time. New-York Mirror (November 1834). Poet of the Body: New York's Walt Whitman: May 15 - July 27, 2019. Recuperado en Noviembre de 2020 , de http://gabrielmckee.hosting.nyu.edu/whitman/items/show/99.

(1980). Leaves of Grass. A Textual Variorum of the Printed Poems (18561866), Vol I, II y III. Nueva York: University Press.

(2019). Hojas de hierba. Traducción, introducción y notas de Eduardo Moga. Barcelona: Galaxia Gutenberg.

(2020). The Original 1855 Edition. Leaves of Grass Walt Whitman.(e-book edition. American Renaissance Books.

(2020). Poems by Walt Whitman. (e-book edition). A Public Domain Book.

Zambrano, M. (1996)., Filosofía y poesía, México D. F.: FCE. 
La poesia y su utilidad histórica: Walt Withman, su obra y la guerra civil.
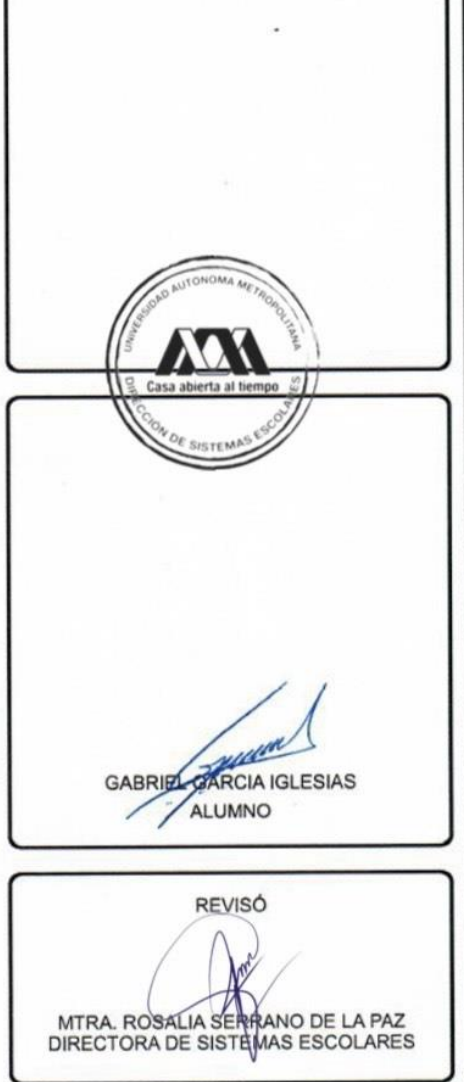

Bajo la Presidencia de la primera y con carácter de Secretario el último, se reunieron para proceder al Examen de Grado cuya denominación aparece al margen, para la obtención del grado de:

MAESTRO EN HUMANIDADES (HISTORIA)

DE: GABRIEL GARCIA IGLESIAS

$y$ de acuerdo con el articulo 78 fracción III del Reglamento de Estudios Superiores de la Universidad Autónoma Metropolitana, los miembros del jurado resolvieron:

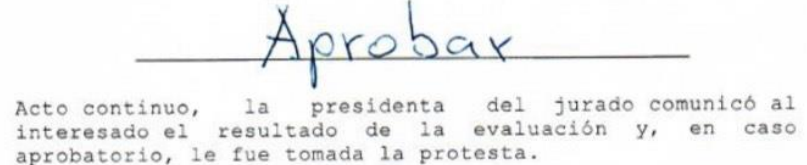

aprobatorio, le fue tomada la protesta.
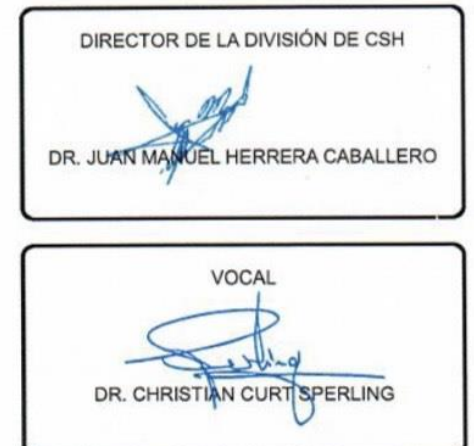

PRESIDENTA

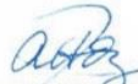

DRA. ADRIANA MARIATERNANDEZ C SANDOVAL

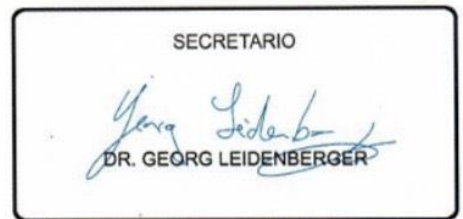

El presente documento cuenta con la firma -autógrafa, escaneada o digital, según corresponda- del funcionario universitario competente, que certifica que las firmas que aparecen en esta acta - Temporal, digital o dictamen- son auténticas y las mismas que usan los c.c. profesores mencionados en ella 